\title{
Engenharia de Materiais e \\ Metalúrgica: Tudo à sua Volta
}

\section{Henrique Ajuz Holzmann}

João Dallamuta Ricardo Vinicius Bubna Biscaia (Organizadores)

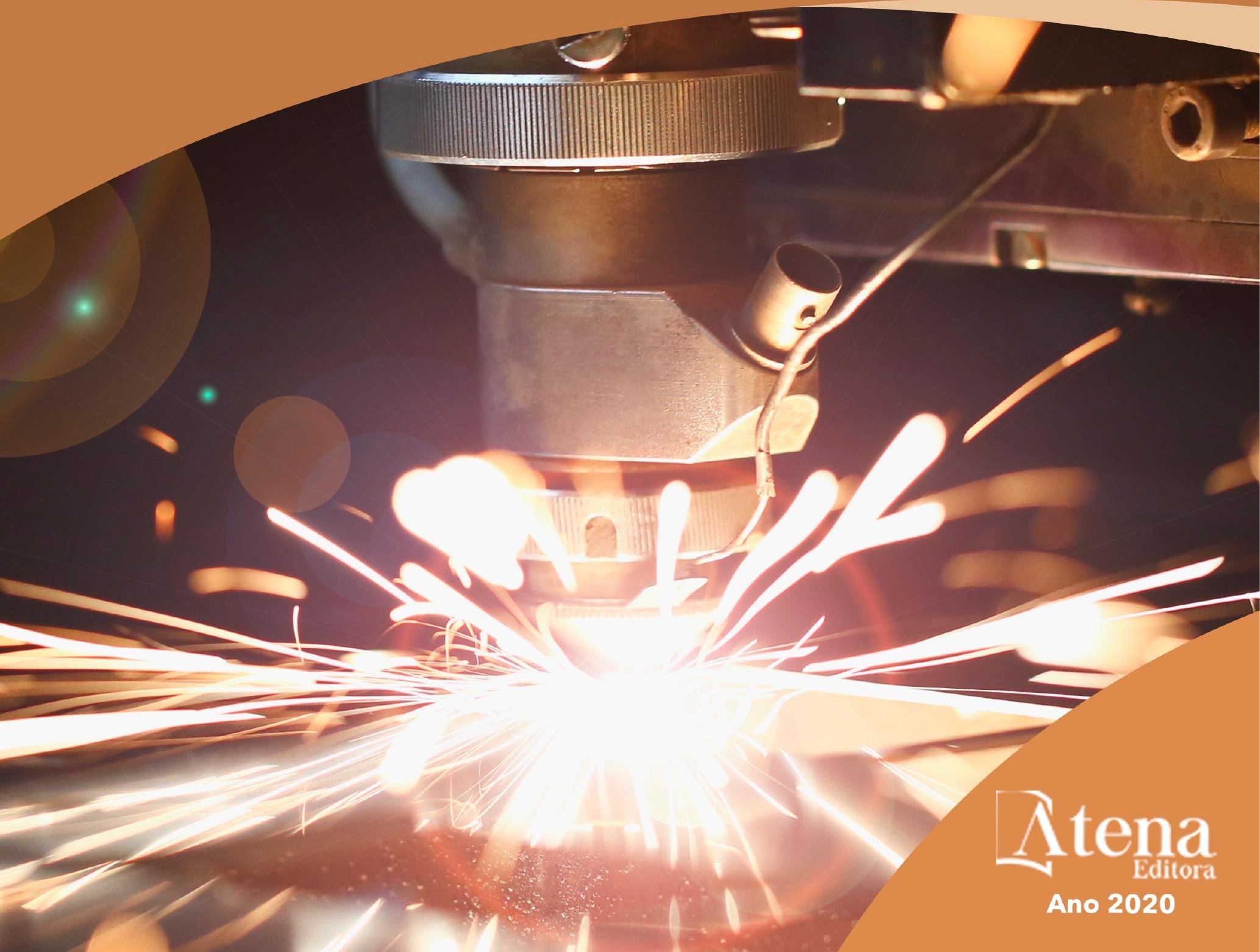




\section{Engenharia de Materiais e \\ Metalúrgica: Tudo à sua Volta}

\section{Henrique Ajuz Holzmann}

João Dallamuta Ricardo Vinicius Bubna Biscaia (Organizadores)

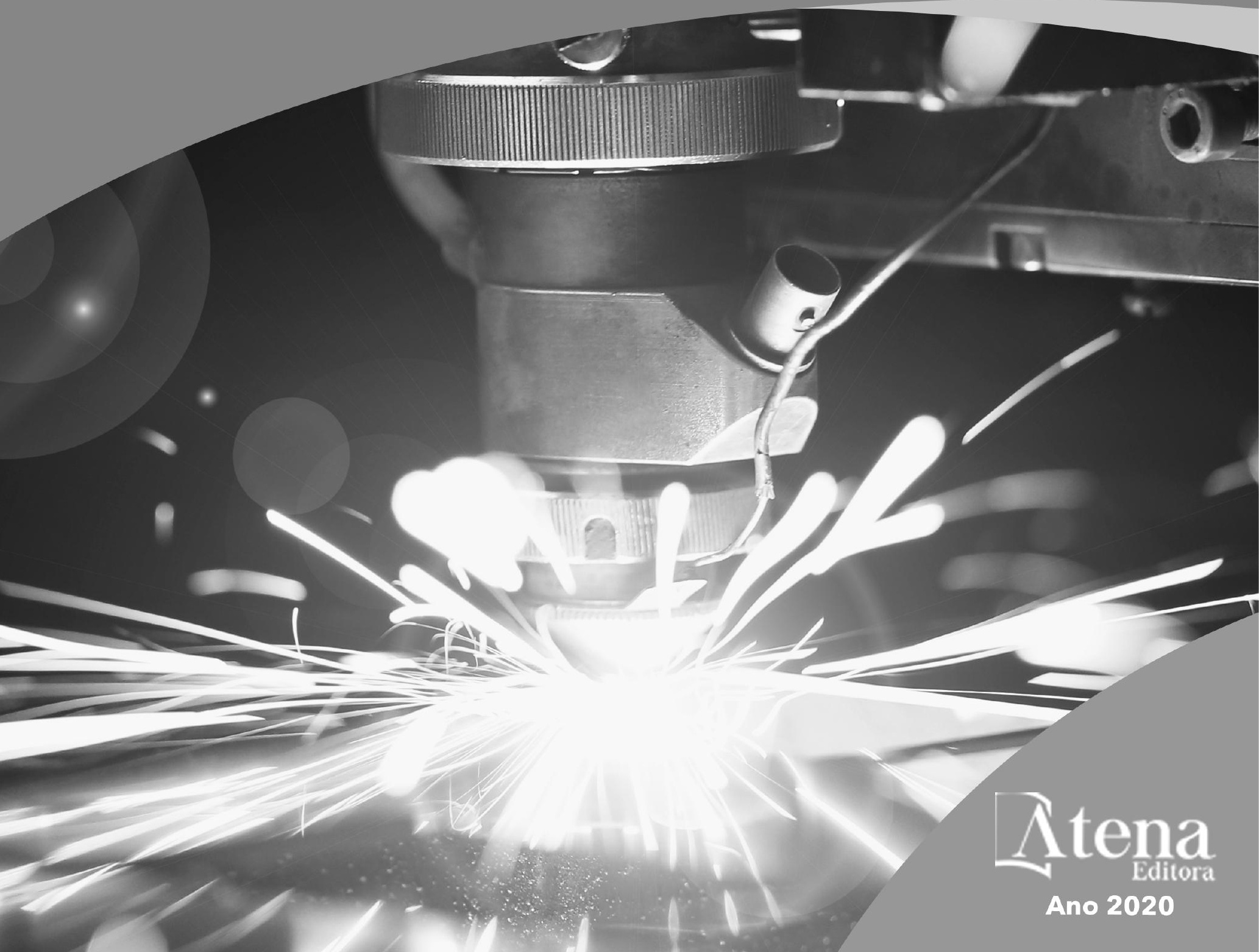




\author{
2020 by Atena Editora \\ Copyright (C) Atena Editora \\ Copyright do Texto (C) 2020 Os autores \\ Copyright da Edição (c) 2020 Atena Editora \\ Editora Chefe: Prof ${ }^{a}$ Dr $^{\mathrm{a}}$ Antonella Carvalho de Oliveira \\ Diagramação: Karine de Lima \\ Edição de Arte: Lorena Prestes \\ Revisão: Os Autores
}

cc) (1) Todo o conteúdo deste livro está licenciado sob uma Licença de Atribuição Creative Commons. Atribuição 4.0 Internacional (CC BY 4.0).

O conteúdo dos artigos e seus dados em sua forma, correção e confiabilidade são de responsabilidade exclusiva dos autores. Permitido o download da obra e o compartilhamento desde que sejam atribuídos créditos aos autores, mas sem a possibilidade de alterá-la de nenhuma forma ou utilizá-la para fins comerciais.

\title{
Conselho Editorial
}

\section{Ciências Humanas e Sociais Aplicadas}

Prof $^{a}$ Dr $^{\text {a }}$ Adriana Demite Stephani - Universidade Federal do Tocantins

Prof. Dr. Álvaro Augusto de Borba Barreto - Universidade Federal de Pelotas

Prof. Dr. Alexandre Jose Schumacher - Instituto Federal de Educação, Ciência e Tecnologia de Mato Grosso

Prof $^{a}$ Dr $^{a}$ Angeli Rose do Nascimento - Universidade Federal do Estado do Rio de Janeiro

Prof. Dr. Antonio Carlos Frasson - Universidade Tecnológica Federal do Paraná

Prof. Dr. Antonio Gasparetto Júnior - Instituto Federal do Sudeste de Minas Gerais

Prof. Dr. Antonio Isidro-Filho - Universidade de Brasília

Prof. Dr. Carlos Antonio de Souza Moraes - Universidade Federal Fluminense

Prof $^{a}$ Dr $^{\text {a }}$ Cristina Gaio - Universidade de Lisboa

Prof $^{\mathrm{a}} \mathrm{Dr}^{\mathrm{a}}$ Denise Rocha - Universidade Federal do Ceará

Prof. Dr. Deyvison de Lima Oliveira - Universidade Federal de Rondônia

Prof. Dr. Edvaldo Antunes de Farias - Universidade Estácio de Sá

Prof. Dr. Eloi Martins Senhora - Universidade Federal de Roraima

Prof. Dr. Fabiano Tadeu Grazioli - Universidade Regional Integrada do Alto Uruguai e das Missões

Prof. Dr. Gilmei Fleck - Universidade Estadual do Oeste do Paraná

Prof. Dr. Gustavo Henrique Cepolini Ferreira - Universidade Estadual de Montes Claros

Prof $^{\mathrm{a}} \mathrm{Dr}^{\mathrm{a}}$ Ivone Goulart Lopes - Istituto Internazionele delle Figlie de Maria Ausiliatrice

Prof. Dr. Julio Candido de Meirelles Junior - Universidade Federal Fluminense

Prof $^{a}$ Dr $^{a}$ Keyla Christina Almeida Portela - Instituto Federal de Educação, Ciência e Tecnologia de Mato Grosso

Prof $^{a}$ Dr $^{\mathrm{a}}$ Lina Maria Gonçalves - Universidade Federal do Tocantins

Prof. Dr. Luis Ricardo Fernandes da Costa - Universidade Estadual de Montes Claros

Prof ${ }^{a}$ Dr $^{a}$ Natiéli Piovesan - Instituto Federal do Rio Grande do Norte

Prof. Dr. Marcelo Pereira da Silva - Universidade Federal do Maranhão

Prof $^{a}$ Dr $^{\mathrm{a}}$ Miranilde Oliveira Neves - Instituto de Educação, Ciência e Tecnologia do Pará

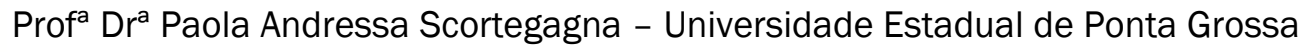

Prof $^{\mathrm{a}} \mathrm{Dr}^{\mathrm{a}}$ Rita de Cássia da Silva Oliveira - Universidade Estadual de Ponta Grossa

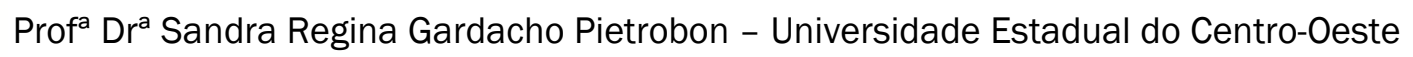

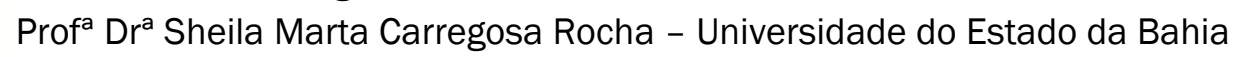

Prof. Dr. Rui Maia Diamantino - Universidade Salvador

Prof. Dr. Urandi João Rodrigues Junior - Universidade Federal do Oeste do Pará

Prof $^{a}$ Dr $^{a}$ Vanessa Bordin Viera - Universidade Federal de Campina Grande

\section{Dtena}


Prof. Dr. William Cleber Domingues Silva - Universidade Federal Rural do Rio de Janeiro

Prof. Dr. Willian Douglas Guilherme - Universidade Federal do Tocantins

\section{Ciências Agrárias e Multidisciplinar}

Prof. Dr. Alexandre Igor Azevedo Pereira - Instituto Federal Goiano

Prof. Dr. Antonio Pasqualetto - Pontifícia Universidade Católica de Goiás

Prof. Dr. Cleberton Correia Santos - Universidade Federal da Grande Dourados

Prof $^{\mathrm{a}} \mathrm{Dr}^{\mathrm{a}}$ Daiane Garabeli Trojan - Universidade Norte do Paraná

Prof $^{a}$ Dra $^{a}$ Diocléa Almeida Seabra Silva - Universidade Federal Rural da Amazônia

Prof. Dr. Écio Souza Diniz - Universidade Federal de Viçosa

Prof. Dr. Fábio Steiner - Universidade Estadual de Mato Grosso do Sul

Prof. Dr. Fágner Cavalcante Patrocínio dos Santos - Universidade Federal do Ceará

Prof $^{a}$ Dr $^{a}$ Girlene Santos de Souza - Universidade Federal do Recôncavo da Bahia

Prof. Dr. Júlio César Ribeiro - Universidade Federal Rural do Rio de Janeiro

Prof $^{a}$ Dr $^{a}$ Lina Raquel Santos Araújo - Universidade Estadual do Ceará

Prof. Dr. Pedro Manuel Villa - Universidade Federal de Viçosa

Prof $^{a}$ Dr $^{\mathrm{a}}$ Raissa Rachel Salustriano da Silva Matos - Universidade Federal do Maranhão

Prof. Dr. Ronilson Freitas de Souza - Universidade do Estado do Pará

Prof $^{a}$ Dr $^{a}$ Talita de Santos Matos - Universidade Federal Rural do Rio de Janeiro

Prof. Dr. Tiago da Silva Teófilo - Universidade Federal Rural do Semi-Árido

Prof. Dr. Valdemar Antonio Paffaro Junior - Universidade Federal de Alfenas

\section{Ciências Biológicas e da Saúde}

Prof. Dr. André Ribeiro da Silva - Universidade de Brasília

Prof $^{\mathrm{a}} \mathrm{Dr}^{\mathrm{a}}$ Anelise Levay Murari - Universidade Federal de Pelotas

Prof. Dr. Benedito Rodrigues da Silva Neto - Universidade Federal de Goiás

Prof. Dr. Edson da Silva - Universidade Federal dos Vales do Jequitinhonha e Mucuri

Prof $^{a}$ Dr $^{a}$ Eleuza Rodrigues Machado - Faculdade Anhanguera de Brasília

Prof $^{a}$ Dr $^{a}$ Elane Schwinden Prudêncio - Universidade Federal de Santa Catarina

Prof $^{a}$ Dr $^{a}$ Eysler Gonçalves Maia Brasil - Universidade da Integração Internacional da Lusofonia Afro-Brasileira

Prof. Dr. Ferlando Lima Santos - Universidade Federal do Recôncavo da Bahia

Prof. Dr. Fernando José Guedes da Silva Júnior - Universidade Federal do Piauí

Prof $^{\mathrm{a}} \mathrm{Dr}^{\mathrm{a}}$ Gabriela Vieira do Amaral - Universidade de Vassouras

Prof. Dr. Gianfábio Pimentel Franco - Universidade Federal de Santa Maria

Prof $^{a}$ Dr $^{\mathrm{a}}$ Iara Lúcia Tescarollo - Universidade São Francisco

Prof. Dr. Igor Luiz Vieira de Lima Santos - Universidade Federal de Campina Grande

Prof. Dr. José Max Barbosa de Oliveira Junior - Universidade Federal do Oeste do Pará

Prof. Dr. Luís Paulo Souza e Souza - Universidade Federal do Amazonas

Prof $^{a}$ Dr$^{a}$ Magnólia de Araújo Campos - Universidade Federal de Campina Grande

Prof. Dr. Marcus Fernando da Silva Praxedes - Universidade Federal do Recôncavo da Bahia

Prof $^{a}$ Dr $^{a}$ Mylena Andréa Oliveira Torres - Universidade Ceuma

Prof $^{\mathrm{a}} \mathrm{Dr}^{\mathrm{a}}$ Natiéli Piovesan - Instituto Federacl do Rio Grande do Norte

Prof. Dr. Paulo Inada - Universidade Estadual de Maringá

Prof $^{a}{ }^{\text {Dr }}{ }^{\mathrm{a}}$ Renata Mendes de Freitas - Universidade Federal de Juiz de Fora

Prof $^{a}$ Dr $^{a}$ Vanessa Lima Gonçalves - Universidade Estadual de Ponta Grossa

Prof $^{a}$ Dr $^{\mathrm{a}}$ Vanessa Bordin Viera - Universidade Federal de Campina Grande

\section{Ciências Exatas e da Terra e Engenharias}

Prof. Dr. Adélio Alcino Sampaio Castro Machado - Universidade do Porto 
Prof. Dr. Alexandre Leite dos Santos Silva - Universidade Federal do Piauí

Prof. Dr. Carlos Eduardo Sanches de Andrade - Universidade Federal de Goiás

Prof $^{a}$ Dr $^{a}$ Carmen Lúcia Voigt - Universidade Norte do Paraná

Prof. Dr. Eloi Rufato Junior - Universidade Tecnológica Federal do Paraná

Prof. Dr. Fabrício Menezes Ramos - Instituto Federal do Pará

Prof. Dr. Juliano Carlo Rufino de Freitas - Universidade Federal de Campina Grande

Prof $^{\mathrm{a}} \mathrm{Dr}^{\mathrm{a}}$ Luciana do Nascimento Mendes - Instituto Federal de Educação, Ciência e Tecnologia do Rio Grande do Norte

Prof. Dr. Marcelo Marques - Universidade Estadual de Maringá

Prof ${ }^{a}$ Dr $^{a}$ Neiva Maria de Almeida - Universidade Federal da Paraíba

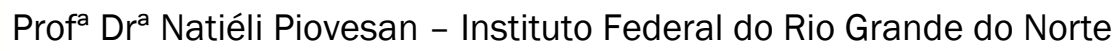

Prof. Dr. Takeshy Tachizawa - Faculdade de Campo Limpo Paulista

\section{Conselho Técnico Científico}

Prof. Me. Abrãao Carvalho Nogueira - Universidade Federal do Espírito Santo

Prof. Me. Adalberto Zorzo - Centro Estadual de Educação Tecnológica Paula Souza

Prof. Me. Adalto Moreira Braz - Universidade Federal de Goiás

Prof. Dr. Adaylson Wagner Sousa de Vasconcelos - Ordem dos Advogados do Brasil/Seccional Paraíba

Prof. Me. André Flávio Gonçalves Silva - Universidade Federal do Maranhão

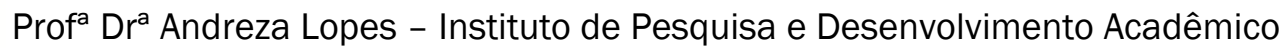

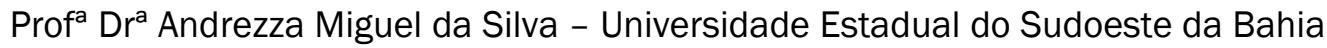

Prof. Dr. Antonio Hot Pereira de Faria - Polícia Militar de Minas Gerais

Prof $^{a}$ Ma. Bianca Camargo Martins - UniCesumar

Prof $^{a}$ Ma. Carolina Shimomura Nanya - Universidade Federal de São Carlos

Prof. Me. Carlos Antônio dos Santos - Universidade Federal Rural do Rio de Janeiro

Prof. Ma. Cláudia de Araújo Marques - Faculdade de Música do Espírito Santo

Prof $^{a}$ Dr $^{a}$ Cláudia Taís Siqueira Cagliari - Centro Universitário Dinâmica das Cataratas

Prof. Me. Daniel da Silva Miranda - Universidade Federal do Pará

Prof ${ }^{a}$ Ma. Daniela da Silva Rodrigues - Universidade de Brasília

Prof ${ }^{\mathrm{a}}$ Ma. Dayane de Melo Barros - Universidade Federal de Pernambuco

Prof. Me. Douglas Santos Mezacas - Universidade Estadual de Goiás

Prof. Dr. Edwaldo Costa - Marinha do Brasil

Prof. Me. Eduardo Gomes de Oliveira - Faculdades Unificadas Doctum de Cataguases

Prof. Me. Eliel Constantino da Silva - Universidade Estadual Paulista Júlio de Mesquita

Prof. Me. Euvaldo de Sousa Costa Junior - Prefeitura Municipal de São João do Piauí

Prof ${ }^{a}$ Ma. Fabiana Coelho Couto Rocha Corrêa - Centro Universitário Estácio Juiz de Fora

Prof. Dr. Fabiano Lemos Pereira - Prefeitura Municipal de Macaé

Prof. Me. Felipe da Costa Negrão - Universidade Federal do Amazonas

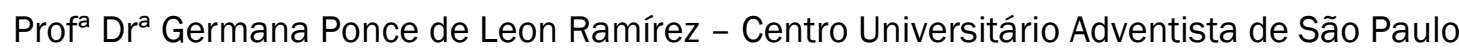

Prof. Me. Gevair Campos - Instituto Mineiro de Agropecuária

Prof. Dr. Guilherme Renato Gomes - Universidade Norte do Paraná

Prof. Me. Gustavo Krahl - Universidade do Oeste de Santa Catarina

Prof. Me. Helton Rangel Coutinho Junior - Tribunal de Justiça do Estado do Rio de Janeiro

Prof $^{a}$ Ma. Jaqueline Oliveira Rezende - Universidade Federal de Uberlândia

Prof. Me. Javier Antonio Albornoz - University of Miami and Miami Dade College

Prof $^{a}$ Ma. Jéssica Verger Nardeli - Universidade Estadual Paulista Júlio de Mesquita Filho

Prof. Me. Jhonatan da Silva Lima - Universidade Federal do Pará

Prof. Me. José Luiz Leonardo de Araujo Pimenta - Instituto Nacional de Investigación Agropecuaria Uruguay

Prof. Me. José Messias Ribeiro Júnior - Instituto Federal de Educação Tecnológica de Pernambuco 
Prof $^{a}$ Ma. Juliana Thaisa Rodrigues Pacheco - Universidade Estadual de Ponta Grossa

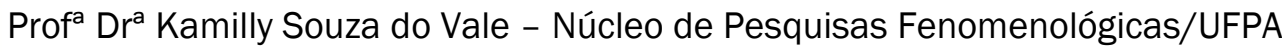

Prof $^{a}$ Dr $^{a}$ Karina de Araújo Dias - Prefeitura Municipal de Florianópolis

Prof. Dr. Lázaro Castro Silva Nascimento - Laboratório de Fenomenologia \& Subjetividade/UFPR

Prof. Me. Leonardo Tullio - Universidade Estadual de Ponta Grossa

Prof $^{a}$ Ma. Lilian Coelho de Freitas - Instituto Federal do Pará

Prof ${ }^{a}$ Ma. Liliani Aparecida Sereno Fontes de Medeiros - Consórcio CEDERJ

Prof $^{a}$ Dr $^{a}$ Lívia do Carmo Silva - Universidade Federal de Goiás

Prof. Me. Lucio Marques Vieira Souza - Secretaria de Estado da Educação, do Esporte e da Cultura de Sergipe Prof. Me. Luis Henrique Almeida Castro - Universidade Federal da Grande Dourados

Prof. Dr. Luan Vinicius Bernardelli - Universidade Estadual do Paraná

Prof. Dr. Michel da Costa - Universidade Metropolitana de Santos

Prof. Dr. Marcelo Máximo Purificação - Fundação Integrada Municipal de Ensino Superior

Prof. Me. Marcos Aurelio Alves e Silva - Instituto Federal de Educação, Ciência e Tecnologia de São Paulo

Prof $^{a}$ Ma. Marileila Marques Toledo - Universidade Federal dos Vales do Jequitinhonha e Mucuri

Prof. Me. Ricardo Sérgio da Silva - Universidade Federal de Pernambuco

Prof. Me. Rafael Henrique Silva - Hospital Universitário da Universidade Federal da Grande Dourados

Prof ${ }^{a}$ Ma. Renata Luciane Polsaque Young Blood - UniSecal

Prof $^{a}$ Ma. Solange Aparecida de Souza Monteiro - Instituto Federal de São Paulo

Prof. Me. Tallys Newton Fernandes de Matos - Faculdade Regional Jaguaribana

Prof. Dr. Welleson Feitosa Gazel - Universidade Paulista

\begin{tabular}{|c|c|}
\hline & $\begin{array}{c}\text { Dados Internacionais de Catalogação na Publicação (CIP) } \\
\text { (eDOC BRASIL, Belo Horizonte/MG) }\end{array}$ \\
\hline \multirow[t]{4}{*}{ E57 } & $\begin{array}{l}\text { Engenharia de materiais e metalúrgica [recurso eletrônico] : tudo à } \\
\text { sua volta / Organizadores Henrique Ajuz Holzmann, Ricardo } \\
\text { Vinicius Bubna Biscaia, João Dallamuta. - Ponta Grossa, PR: } \\
\text { Atena, } 2020 .\end{array}$ \\
\hline & $\begin{array}{l}\text { Formato: PDF } \\
\text { Requisitos de sistema: Adobe Acrobat Reader. } \\
\text { Modo de acesso: World Wide Web. } \\
\text { Inclui bibliografia } \\
\text { ISBN 978-65-5706-108-4 } \\
\text { DOI 10.22533/at.ed.084201506 }\end{array}$ \\
\hline & $\begin{array}{l}\text { 1. Engenharia - Tecnologia. 2. Metalurgia. I. Holzmann, Ajuz. } \\
\text { II. Biscaia, Ricardo Vinicius Bubna. III. Dallamuta, João. } \\
\text { CDD } 620.002854\end{array}$ \\
\hline & Elaborado por Maurício Amormino Júnior - CRB6/2422 \\
\hline
\end{tabular}

Atena Editora

Ponta Grossa - Paraná - Brasil

www.atenaeditora.com.br

contato@atenaeditora.com.br 


\section{APRESENTAÇÃO}

Nos dias atuais, com uma escassez cada vez maior de matéria prima e energia, buscar novas formas de produção ecologicamente corretas é um diferencial ao setor industrial. Neste contexto as pesquisas nesta área veem crescendo e se tornando uma das grandes vertentes da engenharia de materiais, buscando-se a melhoria de materiais, aliando-se novos componentes e reutilizando materiais de descarte.

Neste e-book são explorados trabalhos teóricos e práticos, relacionados ao desenvolvimento de materiais, bem como a reutilização de subprodutos da construção civil, vislumbrando a uma melhoria tanto de novos materiais, como a um descarte inteligente e eficiente de resíduos. De abordagem objetiva, a obra se mostra de grande relevância para graduandos, alunos de pós-graduação, docentes e profissionais, apresentando temáticas e metodologias diversificadas.

Boa leitura!

Henrique Ajuz Holzmann João Dallamuta

Ricardo Vinicius Bubna Biscaia 


\section{SUMÁRIO}

CAPÍTULO 1 1

UM ESTUDO DOS MATERIAIS UTILIZADOS NA CONSTRUÇÃO DAS TURBINAS GERADORAS DE ENERGIA EÓLICA, NOS PARQUES EM PERNAMBUCO

Kaio Moab de Oliveira Silva

Joaci Galindo

Veronica Alves Teixeira

Vitor Bismark Ferreira de Macedo

DOI 10.22533/at.ed.0842015061

CAPÍTULO 2

8

INFLUÊNCIA DA TEMPERATURA DURANTE O PROCESSO DE LAMINAÇÃO TESTADA ATRAVÉS DE ENSAIO DE DUREZA E ENSAIO METALOGRÁFICO

Gabrielle Schultz Braz

Gabriel Inácio Pontin

DOI 10.22533/at.ed.0842015062

CAPÍTULO 3

ANÁLISE DAS JUNTAS SOLDADAS NA UNIÃO DA ESTRUTURA DO VEÍCULO BAJA SAE

Henrique Ajuz Holzmann

Victor Henrique Javara

DOI 10.22533/at.ed.0842015063

CAPÍTULO 4 33

ANÁLISE EXPERIMENTAL E ANALÍTICA DA INFLUÊNCIA DA RAZÃO W/D EM COMPÓSITO POLIMÉRICO DE POLIÉSTER REFORÇADO POR FIBRAS DE VIDRO/JUTA

Raphael Siqueira Fontes

Sérgio Renan Lopes Tinô

Ana Claudia de Melo Caldas Batista

Eve Maria Freire de Aquino

DOI 10.22533/at.ed.0842015064

CAPÍTULO 5 48

EFEITOS DE PÓS CERÂMICOS ATIVOS NAS PROPRIEDADES DE COMPÓSITOS POLIMÉRICOS À BASE DE PVDF

Eriton Rodrigo Botero

Jaldair de Araújo e Nóbrega

DOI 10.22533/at.ed.0842015065

CAPÍTULO 6 62

SÍNTESE DE NANOPARTÍCULAS DE PRATA OBTIDAS VIA ROTAS QUÍMICA E ELETROQUÍMICA E SUA OTIMIZAÇÃO

Arthur da Rocha Albertini

Guilherme Frederico Bernardo Lenz e Silva

Rodrigo Labat Marcos

DOI 10.22533/at.ed.0842015066

CAPÍTULO 7 80

TRANSFORMAÇÃO DE REJEITOS DE LAVAGEM DE BAUXITA DA AMAZÔNIA EM MATERIAL TIPO HIDROGROSSULAR (KATOITA) DE Ca ${ }_{3} \mathrm{Fe} / \mathrm{Al}_{2}\left(\mathrm{OH}_{4}\right)_{3}$

Renata de Sousa Nascimento

Bruno Apolo Miranda Figueira 
DOI 10.22533/at.ed.0842015067

CAPÍTULO 8 87

AVALIAÇÃO DAS PROPRIEDADES DO CONCRETO ATRAVÉS DA ADIÇÃO DE FIBRAS DO COCO BABAÇU

Márcio do Nascimento Silva

Deuzuíta dos Santos Freitas Viana

Lívia Racquel de Macêdo Reis

Wendel Melo Prudêncio de Araújo

DOI 10.22533/at.ed.0842015068

CAPÍTULO 9 94

COMPARAÇÃO DA RESISTÊNCIA À COMPRESSÃO AXIAL DE CONCRETOS DE ALTA RESISTÊNCIA (CAR) COM INSERÇÃO DE NANOTUBOS DE CARBONO (NTC) E CINZAS DE CASCA DE ARROZ (CCA)

Christa Korzenowski

Rosangel Rojas Aguero

Ronaldo Beraldin da Silva

Priscila Marques Correa

Luiz Carlos Pinto Silva Filho

DOI 10.22533/at.ed.0842015069

SOBRE OS ORGANIZADORES. 


\section{UM ESTUDO DOS MATERIAIS UTILIZADOS NA CONSTRUÇÃO DAS TURBINAS GERADORAS DE ENERGIA EÓLICA, NOS PARQUES EM PERNAMBUCO}

Data de aceite: 05/06/2020

Kaio Moab de Oliveira Silva Licenciando em Física IFPE/Campus Pesqueira moabk@hotmail.com

Joaci Galindo

Docente IFPE Campus/Pesqueira joaci@pesqueira.ifpe.edu.br Veronica Alves Teixeira Licenciando em Física IFPE/Campus Pesqueira veronicaalvesteixeira@gmail.com Vitor Bismark Ferreira de Macedo Bacharelando em Engenharia Elétrica IFPE/

Campus Pesqueira vitor.bismark@hotmail.com

RESUMO: O presente estudo verificou o funcionamento e instalação de aerogeradores, com ênfase no Complexo Ventos de São Clemente, em atividade na região agreste do estado de Pernambuco, e trata de tornar evidente as vantagens e benefícios na implantação destes parques eólicos, que agregam mudanças ambientais significativas no processo de geração e uso da energia elétrica em condições sustentáveis. A região nordeste do Brasil reúne inúmeras condições favoráveis para instalação de parques eólicos e o estado de Pernambuco é detentor de um percentual significativo deste potencial. Em síntese, o estudo trata de mostrar o funcionamento de uma turbina (gerador), que transforma a energia mecânica dos ventos em energia elétrica. $O$ incremento da oferta de energia a partir dos parques eólicos tem contribuído na diminuição dos impactos ambientais relativos ao uso energético, e garantido maior sustentabilidade às matrizes energéticas dos países. Os dados e escritos publicados através da Casa dos Ventos, responsável pela construção do complexo Ventos de São Clemente foram tratados como importantes dentro desta temática. O estudo em tela, certamente contribuirá para o aumento do conhecimento sobre geradores eólicos, parques eólicos e energia eólica, por exemplo; entendendo que esta já constitui uma das principais fontes de energia de muitos países, inclusive do Brasil.

PALAVRAS-CHAVE: energia eólica, parques eólicos, ventos, aerogeradores.

ABSTRACT: This study verified the operation and installation of wind turbines, with emphasis on the Ventos de São Clemente Complex, active in the region called as Agreste in the state of Pernambuco, and seeks to highlight the advantages and benefits in the implementation 
of these wind farms, which add significant environmental changes in the process of generating and using electricity under sustainable conditions. The northeast region of Brazil has many favorable conditions for the installation of wind farms and the state of Pernambuco holds a significant percentage of this potential. In summary, the study aims to show the functioning of a turbine (generator), which transforms the mechanical energy of the winds into electrical energy. The increase in the supply of energy from wind farms has contributed to the reduction of environmental impacts related to energy use, and guaranteed greater sustainability to the countries' energy matrices. The data and writings published through the Casa dos Ventos, responsible for the construction of the Ventos de São Clemente complex were treated as important within this theme. The study will certainly contribute to increasing knowledge about wind generators, wind farms and wind energy, for example, understanding that this is already one of the main sources of energy in many countries, including Brazil.

KEYWORDS: wind energy, wind farms, winds, wind turbines.

\section{I INTRODUÇÃO}

O desenvolvimento energético no estado de Pernambuco tem crescido exponencialmente quanto à oferta de energia elétrica a partir da geração eólica. Em um período de quase uma década, o estado assumiu posição de destaque quanto à geração de energia elétrica envolvendo parques eólicos, em função de seu relevo e do aporte de investimentos oriundos do Brasil e de outros países, principalmente europeus.

Agarantia de bons ventos no território do estado de Pernambuco, tem contribuído para o uso cada vez mais abrangente deste recurso natural, o que tem permitindo o acesso sustentável da ordem de centenas de megawatts de energia elétrica por parque em funcionamento. A utilização em escala gigantesca dos recursos naturais em todo o planeta, principalmente os fósseis, tem levado os países a reverem suas matrizes energéticas em função das altas concentrações de gases impactantes na atmosfera, como nos casos do dióxido de carbono $\left(\mathrm{CO}_{2}\right)$, monóxido de carbono (CO), metano $\left(\mathrm{CH}_{4}\right)$, entre outros.

Sabendo que os ventos constituem matéria prima quase inesgotável, entendese que a energia elétrica proveniente de parques eólicos pode ser considerada inteiramente renovável e de baixo impacto ambiental, se comparada à geração proveniente das termelétricas e hidrelétricas, ainda dominantes na matriz energética brasileira.

O complexo Ventos de São Clemente, localizado na região Agreste do estado de Pernambuco é composto por parques eólicos instalados nos municípios de Caetés, Pedra, Venturosa e Capoeiras. O referido complexo foi projetado e construído pela 
empresa Casa dos Ventos, pioneira na área tecnológica envolvendo energia eólica, mesmo tendo iniciado os seus maiores projetos a partir de 2007 na região nordeste do Brasil.

Segundo M. Araripe (2016), também empreendedor da Casa dos Ventos, o complexo de São Clemente entrou em operação em 2016, sendo classificado como o maior em operação no estado de Pernambuco. Em conformidade com Casa dos Ventos (2019), o parque possui ao todo 126 aerogeradores e capacidade de potência máxima de 216,1 MW, suficiente para fornecer energia elétrica a aproximadamente 551 mil residências, considerando a média de uso em kWh da maioria das residências brasileiras.

Os aerogeradores ou turbinas, são responsáveis por transformar, com o uso de dispositivos eletromagnéticos, a energia cinética dos ventos em energia elétrica. Para F.R. Martins et al (2019), a aceleração dos ventos é diretamente proporcional a força resultante dos ventos, assim quanto maior for a aceleração maior será a força ou quanto maior a força maior será a aceleração dos ventos, com base nos princípios elementares da aerodinâmica.

\section{I DISPOSITIVOS ELETROMAGNÉTICOS E MECÂNICOS UTILIZADOS NOS PARQUES EÓLICOS}

Cada dispositivo da estrutura da torre (Figura 01) é responsável por uma função específica na transformação da energia eólica em elétrica. As pás são, em geral, fabricadas de fibra de vidro ou de carbono e responsáveis por interceptar os ventos, enviando a sua energia mecânica para o rotor, responsável pelo movimento circular e com um sistema capaz de controlar sua rotação ou até mesmo parar o movimento das pás.

Em relação às torres, estas são responsáveis pela sustentação de toda a estrutura física, fabricadas em aço muito resistente e montadas em base de concreto, já que as naceles que ficam suspensas pelas torres, podem atingir uma massa de 72 toneladas e são feitas de fibra de vidro. Na parte interna das naceles temos as caixas de transmissão com componentes elétricos que tem como principal função o controle das variações da velocidade dos ventos, assim os geradores transformam a energia cinética dos ventos em energia elétrica.

Todo esse processo de transformação de energia eólica em elétrica inicia com a movimentação dos ventos, quando os raios solares atingem o solo; o calor emanado desses raios é absorvido por parte do ar, assim o ar mais quente tende a se elevar,com base no princípio da convecção - porque o ar quente é mais leve que o ar frio, e por sua vez o ar frio ocupa o espaço deixado pelo ar aquecido, essa movimentação 
do ar mais frio é o vento. O transporte de grande parte dos componentes de um aerogerador é feito por caminhões, em rodovias ou via marítima.

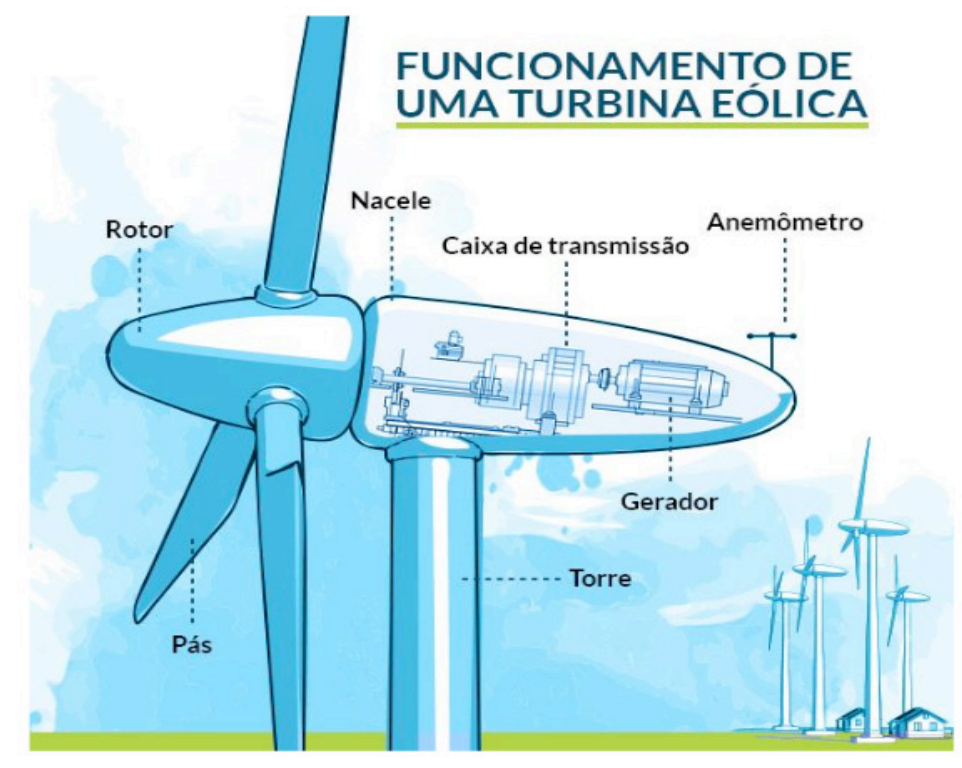

Figura 01: Subdivisões de uma turbina geradora de energia eólica.

Fonte:http://atlanticenergias.com.br/saiba-como-funciona-o-aerogerador-que-transforma-vento-em-eletricidade

\section{I COMPLEXO VENTOS DE SÃO CLEMENTE}

O Complexo Ventos de São Clemente foi inaugurado em 30 de maio de 2016, mas apenas em junho do mesmo ano iniciou suas operações comerciais. Suas instalações contempla os municípios de Caetés, Pedra, Venturosa e Capoeiras, situados no agreste pernambucano. Ao todo conta com uma extensão territorial de 3700 hectares, composto por 126 aerogeradores, e capacidade de 216,1 MW, capaz de alimentar energeticamente 551 mil casas e investimento estimado em 1,2 bilhões de reais. Os parques eólicos vêm mudando a paisagem do estado de Pernambuco, com a implementações destes parques. Além de Pernambuco figurar com bons ventos, a importação de componentes é feita através do Porto de Suape, e a fabricação das pás e torres são feitas no próprio Complexo Portuário de Suape, especificamente envolvendo os municípios do Cabo de Santo Agostinho e Ipojuca. 


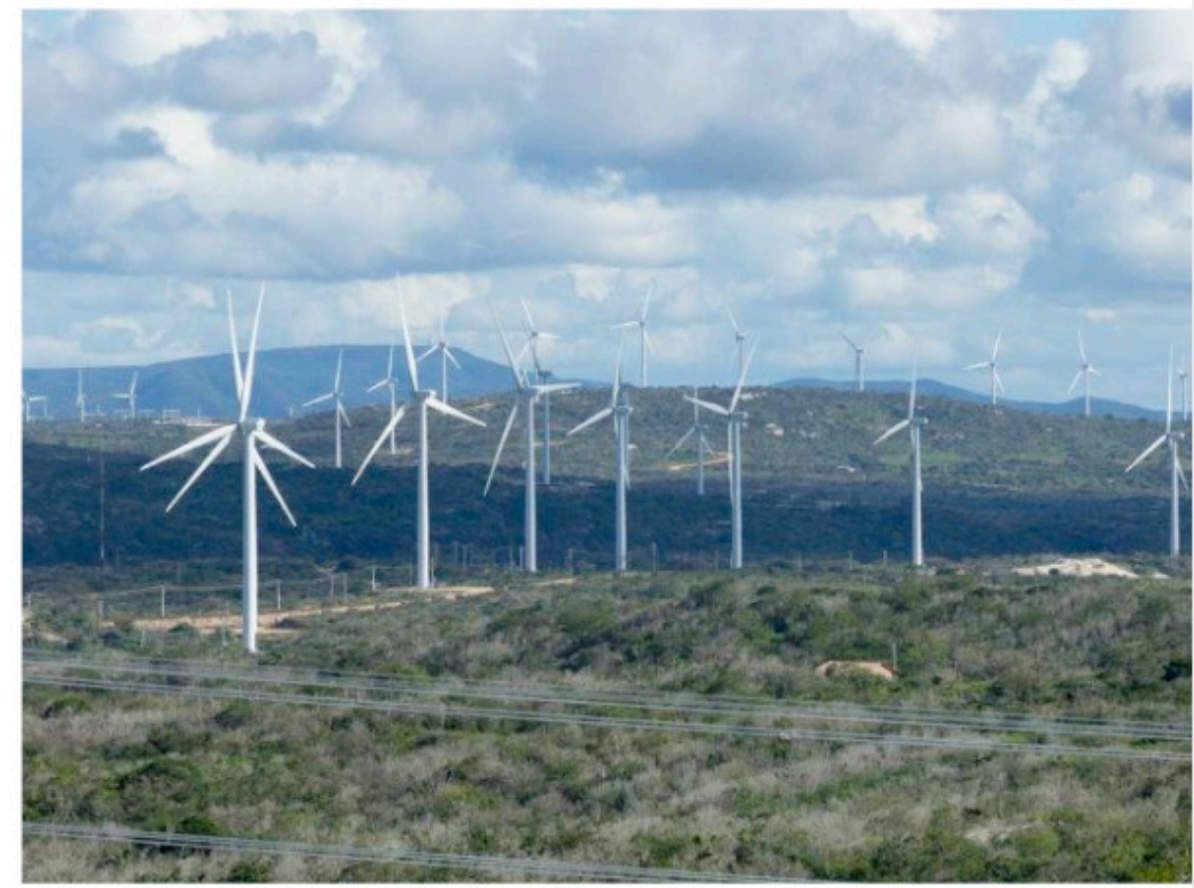

Figura 02:Complexo Ventos de São clemente.

Fonte:https://www.echoenergia.com.br/o-que-fazemos/energia-eolica/complexo-eolico-sao-clemente/

Segundo estudos e dados relacionados com o Banco do Nordeste do Brasil, as fontes de energias eólicas são responsáveis por $37,2 \%$ da matriz energética do nordeste, contribuindo para que as fontes hidroelétricas tenham reduzido o seu percentual e registrem apenas 31,5\%. Considerem-se estes dados como referentes ao ano de 2016, disponibilizados pela Casa dos Ventos, empresa responsável pela construção dos parques eólicos aqui tratados.

\section{I CONCLUSÃo}

A implantação de um parque eólico engloba, em geral, um projeto bastante dispendioso, pois os materiais e componentes utilizados nas turbinas (geradores), assim como a construção de enormes torres, que precisam de uma logística de transporte, incluindo as enormes pás devido as medidas quase incompatíveis com as rodovias, transformam-se em verdadeiros desafios quanto a chegada ao destino final, que são os futuros parques eólicos.

A instalação de um parque eólico em geral envolve uma série de outros investimentos, como o arrendamento do espaço onde vão ficar as torres e uma área mais abrangente, de segurança e de outras aplicações, como as de instalação de pequenas subestações elétricas, entre outros.

Sendo assim, ressalte-se que todo o conjunto uma vez instalado, apresenta longa durabilidade, podendo realizar a transformação eólica-elétrica por décadas, apenas sendo necessário a manutenção dos equipamentos que geralmente segue 
um protocolo ou ocorre por questões de imprevisibilidade. Assim, os parques eólicos apresentam elevada viabilidade econômica e já competem economicamente com todas as outras formas de geração elétrica das matrizes, inclusive as térmicas.

Os parques eólicos são indispensáveis na busca pelo uso da energia de baixo impacto ambiental e de baixo carbono, e minimizam o acesso sem controle dos recursos naturais do planeta. Os ventos como força motora e a exclusão de qualquer outro combustível, torna um parque eólico como algo bastante competitivo, se considerarmos que atualmente os aerogeradores já atingem potência de até 10 MW por unidade, não sendo este o caso do Brasil ainda.

Constatou-se que para suportar as estruturas dos parques eólicos os materiais utilizados em seus equipamentos devem ser resistentes, e em sua grande maioria são usados metais que garantem durabilidade e qualidade, quando considerado o longo tempo envolvido e a busca por maior resistência.

A garantia de níveis de sustentabilidade elevados em relação à outras fontes, têm deixado a geração elétrica através de parques eólicos na dianteira de outros projetos inteiramente impactantes, como são os casos das usinas termelétricas, hidroelétricas e nucleares, por exemplo. A futuras gerações certamente que não irão conhecer os combustíveis fósseis, especificamente petróleo, gás natural e carvão mineral se os principais países não mudarem radicalmente as suas matrizes energéticas.

Os parques eólicos garantem certa sustentabilidade, porque a eles estão associados apenas emissões mínimas no processo que envolve a produção das estruturas, considerando que no funcionamento diário utilizam apenas a forças dos ventos como elemento energético motor.

O uso de fontes energéticas renováveis e de baixo impacto ambiental contribui na diminuição das emissões de gases que surgem como vilões das mudanças climáticas e que tem sido objeto de intenso debate global, juntamente com outras emissões associadas à queima das florestas, inclusive no Brasil.

Portanto, torna-se evidente a importância do uso de fontes energéticas de baixíssimo impacto, como as eólicas e solares, que comprovadamente estarão ainda sendo usadas por inúmeras gerações e, certamente, passando por transformações tecnológicas que garantam maior eficiência e maior potência, por exemplo, garantindo o uso da energia às futuras gerações que ainda estão por vir ao planeta.

\section{REFERÊNCIAS}

Atlantic Energia Renováveis S.A. Disponível em http://atlanticenergias.com.br/saiba-como-funciona-oaerogerador-que-transforma-vento-em-eletricidade/ acesso em 30 de abril de 2019, às 9h15min; 
Casa dos ventos energia para um novo mundo, conheça os componentes da Energia Eólica. Disponível em http://casadosventos.com.br/pt/12-cdv-na-midia/228-conheca-os-componentes-daenergia-eolica, acesso em 29 de abril de 2019 às 14h00min.

Casa dos ventos energia para um novo mundo, projetos desenvolvidos. Disponível em http:// casadosventos.com.br/pt/projetos/parques-eolicos, acesso em 29 de abril de 2019 às 10h00min;

Casa dos ventos energia para um novo mundo, casa dos ventos inaugura maior complexo eólico de Pernambuco. Disponível em http://casadosventos.com.br/pt/nosso-compromisso/missao-evalores/139-casa-dos-ventos-inaugura-maior-complexo-eolico-de-pernambuco, acesso em 30 de abril de 2019 às 17 h00min;

Casa dos ventos energia para um novo mundo, a caminho da geração de energia limpa. Disponível em http://casadosventos.com.br/pt/12-cdv-na-midia/207-a-caminho-da-geracao-de-energia-limpa, acesso em 29 de abril de 2019 às 14h23min;

Echoenergia energia eólica ventos de São Clemente. Disponível em https://www.echoenergia.com. br/o-que-fazemos/energia-eolica/complexo-eolico-sao-clemente/, acesso 01 de maio de 2019 às 9h42min;

F. R. Martins, R. A. Guarnieri e E. B. Pereira. O aproveitamento da energia eólica. Disponível em http://www.sbfisica.org.br/rbrf/pdf/301304.pdf, acesso em 01 de maio de 2019 às 14h21min; 


\section{INFLUÊNCIA DA TEMPERATURA DURANTE O PROCESSO DE LAMINAÇÃO TESTADA ATRAVÉS DE ENSAIO DE DUREZA E ENSAIO METALOGRÁFICO}

Data de aceite: 05/06/2020

Data de Submissão: 12/03/2020

Gabrielle Schultz Braz Centro Universitário da Fundação Educacional de Barretos Barretos - São Paulo

Gabriel Inácio Pontin Centro Universitário da Fundação Educacional de Barretos Barretos - São Paulo

RESUMO: O aço é um componente importante, pois atualmente tem se destacado por ser um material $100 \%$ reciclável, devido a isso o presente trabalho buscou verificar através de ensaios, tanto de dureza quanto metalográfico, o quanto a temperatura durante o processo de laminação das chapas de aço AISI 1020 influenciaria nas características desse metal. Com essas características, poderá definir para onde e como deverá ser aplicado esse material.

PLAVARAS-CHAVE: Propriedades. Aço. Chapas. Ensaios.
INFLUENCE OF TEMPERATURE DURING

THE LAMINATION PROCESS TESTED BY

HARDNESS TEST AND METALLOGRAPHIC

\section{TEST}

ABSTRACT: Steel is an important component, because it is currently a $100 \%$ recyclable material, because of this the present work sought to verify through tests, both hardness and metallographic, as the temperature during the process of lamination of AISI 1020 steel plates would influence the characteristics of this metal. With these characteristics, you can define where and how this material should be applied. KEYWORDS: Properties. Steel. Plates. Tests.

\section{I INTRODUÇÃO}

O aço por causa das suas características é reaproveitado para a transformação de outros produtos tornando o processo produtivo mais sustentável, deixando claro sua importância para a indústria, comercio e meio ambiente.

O processo de laminação, que é quando após termos os lingotes e através da força de atrito entre rolos, formam-se chapas. Essas chapas vão se deformando, normalmente diminuindo sua espessura e assim aumentando 
seu comprimento. Esse processo pode ser realizado tanto a quente, que é quando necessitamos de uma grande deformação nas chapas, tanto a frio, que é quando necessitamos de acabamento superficial.

Mediante essa diferença de temperatura de trabalho as propriedades do aço podem ser modificadas, o que nos leva a pensar o grau dessa mudança. Através desse questionamento realiza-se ensaios para determinar quantitativamente e qualitativamente as propriedades afetam. Tais ensaios são de Dureza e Metalografia.

Como objetivo geral, esta pesquisa foi desenvolvida para determinar a influência da temperatura durante a laminação das chapas, nesse caso diferenciando processo a quente e a frio, nas propriedades mecânicas do aço AISI 1020. Onde pretende verificar tal influencia, a partir da utilização dos ensaios dureza e de metalografia, quais os parâmetros que foram alterados e analisar seus comportamentos.

\section{I REFERENCIAL TEÓRICO}

\subsection{Propriedades dos Aços 1020}

O aço é uma liga ferro-carbono, onde nas indústrias seu uso é em grande quantidade e diversidade, sendo que o aço AISI 1020 se considera um aço macio, possuindo algumas características descritas na Tabela 1.

\begin{tabular}{c|cccccc} 
Densidade & $\begin{array}{c}\text { Teor de } \\
\text { Carbono }\end{array}$ & $\begin{array}{c}\text { Resistencia } \\
\text { a Ruptura }\end{array}$ & $\begin{array}{c}\text { Limite de } \\
\text { Escoamento }\end{array}$ & $\begin{array}{c}\text { Resistencia a } \\
\text { Tração }\end{array}$ & $\begin{array}{c}\text { Modulo de } \\
\text { Elasticidade }\end{array}$ & $\begin{array}{c}\text { Condutividade } \\
\text { Térmica }\end{array}$ \\
\hline $7,87 \mathrm{~g} / \mathrm{cm}^{3}$ & $\begin{array}{c}0,15 \% \text { a } \\
0,30 \%\end{array}$ & $\begin{array}{c}440 \text { a } 540 \\
\mathrm{MPa}\end{array}$ & $350 \mathrm{MPa}$ & $420 \mathrm{MPa}$ & $205 \mathrm{GPa}$ & $51,9 \mathrm{~W} / \mathrm{mK}$ \\
\hline
\end{tabular}

Tabela 1: Características do aço SAE 1020.

Fonte: Adaptada de Luz, 2017.

Além das características descritas acima, o aço AISI 1020 possui baixa temperabilidade, pode ser maleável, soldável, ter uma boa usinabilidade, fácil manipulação usando qualquer método convencional por ser dúctil.

Além de, poder ser endurecido pelo aquecimento entre 815 a $871^{\circ} \mathrm{C}$ seguido de resfriamento a água, poder passar por revenimento, se forjado deve ser entre $1260^{\circ} \mathrm{C}$ e $982^{\circ} \mathrm{C}$, pode ser conformado mais facilmente se mantido entre 482 e $649^{\circ} \mathrm{C}$. Onde também é possível realizar trabalho a frio usando qualquer método tradicional, recozer totalmente este material usando temperaturas entre 871 a $982^{\circ} \mathrm{C}$ seguindo-se a um resfriamento bem lento (LUZ, 2017).

Seus usos são bem variados, tendo como exemplo barras laminadas e perfiladas, peças comuns de mecânica, parafusos, trefilados duros, chassis, discos 
de roda, peças em geral para máquinas e veículos submetidos a esforços pequenos e médios, entre outros.

Com base em dados da ETPC (2012), as chapas para a laminação a quente ficam no forno durante um intervalo de temperatura de $1100^{\circ} \mathrm{C}$ a $1200^{\circ} \mathrm{C}$, com isso percebe-se através da Figura 1 que está na fase austenita ( $\mathrm{Y}$ ), marcada em vermelho, podendo ser confirmado através do ensaio de metalografia.
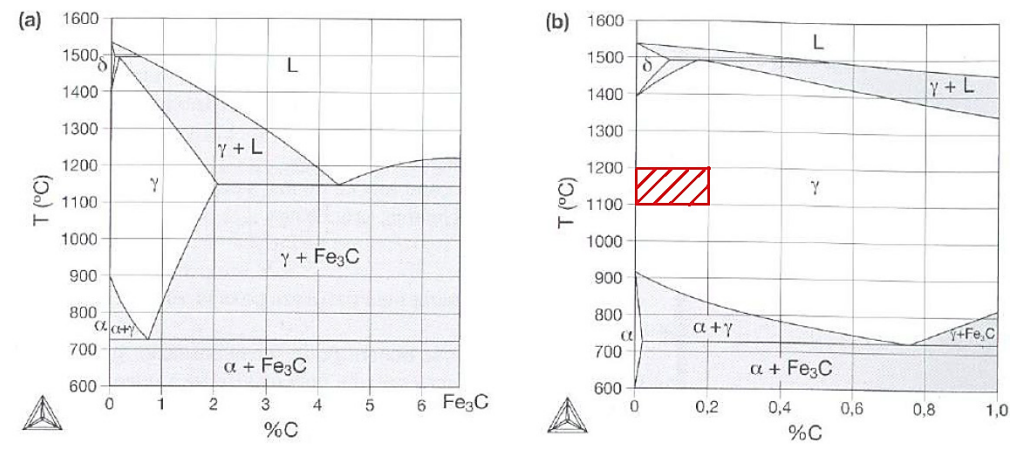

Figura 1: Diagrama de fases: (a) variando d $0 \%$ a $6 \%$; (b) variando de $0 \%$ a $1 \%$. Fonte: Colpaert, 2008.

\subsection{Processo De Fabriação Das Chapas}

O processo de fabricação das chapas se dá através da retirada de matéria prima de seus devidos locais até a fabricação do aço, que consiste em 5 etapas principais, sendo elas: preWparação da matéria prima, local onde o carvão se transforma em coque e o minério de ferro se transforma em minério processado, redução do minério de ferro, ocorre a transformação do coque, cal junto com o minério processado em ferro gusa, refino, lingotamento e laminação.

A produção do aço propriamente dita é realizada nas chamadas aciarias, ou seja, o refino, que é onde o ferro-gusa terá seu teor de carbono diminuído a níveis desejáveis (<2\%). Depois de completado todo o trabalho de refino, o aço já possui a composição química desejada e é em seguida submetido a um processo de conformação mecânica, antes de passar para a fase de laminação, que é lingotamento, seja ela convencional ou contínuo.

A última fase do processo siderúrgico, é a laminação, onde o aço é submetido a tratamentos físicos e químicos com o intuito de conformá-lo mecanicamente de acordo com a realidade de suas aplicações. Nessa fase serão produzidos os produtos siderúrgicos como bobinas, tarugos, arames, vergalhões, perfilados, barras, fios, entre outros.

Os laminadores, em relação às condições operacionais, podem funcionar a frio ou a quente. De acordo com a forma dos produtos produzidos, eles podem ser classificados como planos ou longos, que podem incluir trilhos, perfis, arames, 
entre outros (EMPRESA DE PESQUISA ENERGÉTICA, 2009).

\subsection{Ensaio De Dureza Rockwell}

Segundo Garcia (2012), a dureza Rockwell que recebeu esse nome pelo fato de a sua proposta ter sido feita pela indústria Rockwell, dos Estados Unidos, por volta de 1922, sendo o método mais utilizado internacionalmente, onde utiliza-se da profundidade da impressão causada por um penetrador sob a ação de uma carga aplicada em dois estágios (pré-carga e carga suplementar) como indicador da medida de dureza, e não há relação com a área da impressão, como no caso da dureza Brinell.

A dureza Rockwell pode ser classificada como comum ou superficial, dependendo da pré-carga e carga aplicadas. A Figura 3 apresenta uma representação do princípio de medição de dureza pelo método Rockwell, destacando as deformações causadas pelas aplicações da pré-carga e carga principal. Originalmente o método foi proposto em kgf e polegadas, mas, devido à adoção do Sistema Internacional (SI) de unidades, os valores foram convertidos para $\mathrm{N}$ e $\mathrm{mm}$, sendo prática comum se referir às unidades inicialmente propostas.

O penetrador tanto pode ser um diamante esferocôníco com ângulo de $120^{\circ} \mathrm{e}$ ponta ligeiramente arredondada $(r=0,2 \mathrm{~mm}$ ) como uma esfera de aço endurecido ou carboneto de tungstênio, geralmente com diâmetro de 1,59 mm (1/16"), existindo também nos diâmetros de 3,17 mm (1/8"), 6,35 mm ( 1/4") e 12,70 mm (1/2"). Atualmente a norma ASTM EI 8:2007 só admite a utilização de esferas de carboneto de tungstênio, recomendando as esferas de aço somente no caso de medições em filmes finos e materiais extremamente moles.

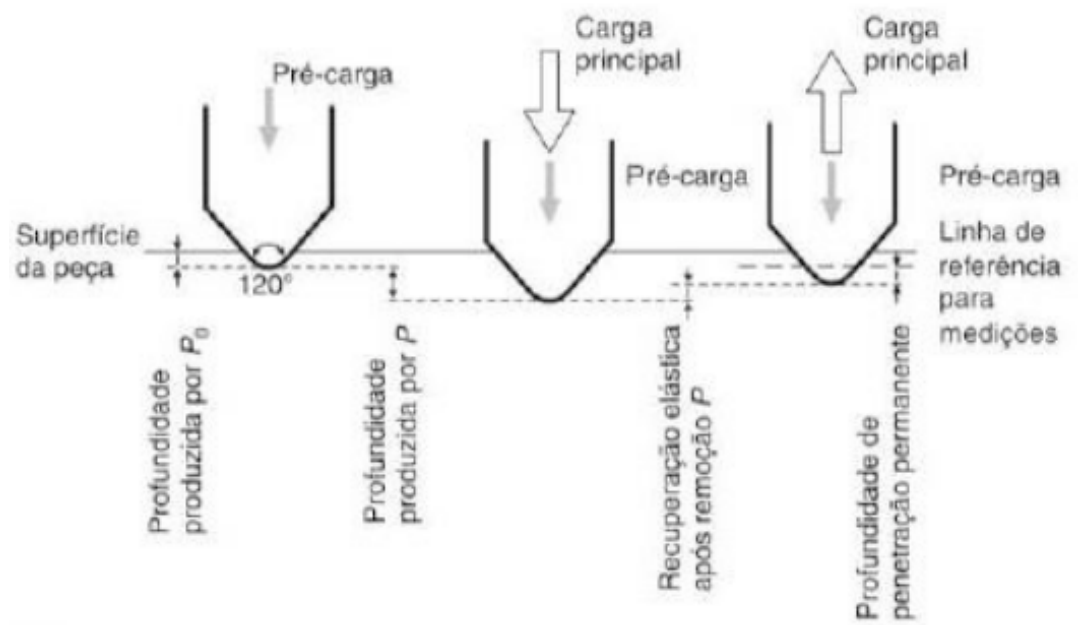

Figura 3: Representação esquemática do ensaio Rockwell.

Fonte: Garcia, 2012.

No caso de ensaios de dureza Rockwell comum, utilizam-se pré-carga de 98 $\mathrm{N}(10 \mathrm{kgf})$ e carga ou força total de $589 \mathrm{~N}$ (60 kgf); $981 \mathrm{~N}$ (100 kgf) e $1471 \mathrm{~N}$ (150 
kgf); e, para dureza superficial, pré-carga de $29 \mathrm{~N}$ (3 kgf) e forças totais de $147 \mathrm{~N}$ (15 kgf), $294 \mathrm{~N}$ (30 kgf) e $441 \mathrm{~N}$ (45 kgf).

A profundidade de penetração ( $p)$ é correlacionada, pela máquina de ensaio, a um número arbitrário, cuja leitura é feita diretamente na escala do equipamento, após a retirada da carga principal, mantendo-se, entretanto, a carga inicial ou précarga.

Como o método utiliza vários penetradores e cargas, este é dividido em escalas dependendo das combinações. O número de dureza Rockwell é sempre designado pelo símbolo HR seguido da escala utilizada, precedidos do valor numérico.

\subsection{Ensaio Metalográfico}

Segundo Fernandes (2013), metalografia é o estudo da morfologia e estrutura dos metais. Para a realização da análise, o plano de interesse da amostra é cortado, lixado, polido e atacada com reagente químico, de modo a revelar as interfaces entre os diferentes constituintes que compõe o metal.

(a) Quanto ao tipo de observação, está subdividida, basicamente em duas classes:

- Microscopia, análise feita em um microscópio com aumentos que normalmente são 50X, 100X, 200X, 500X, 1000X, 1500X e 2500X. Este tipo de análise é realizado em microscópios específicos, conhecidos como "microscópios metalográficos" ou "microscópios metalúrgicos". Este tipo de microscópio possui baixo campo focal, permitindo apenas a observação de superfícies perfeitamente planas e polidas. Em razão disto, a preparação metalográfica tem grande importância na qualidade de uma análise. Estes microscópios, em geral, possuem sistemas de fotografia integrados, que permitem o registro das análises realizadas.

- Macroscopia, análise feita a olho nu, lupa ou com utilização de microscópios estéreos (que favorecem a profundidade de foco e dão, portanto, visão tridimensional da área observada) com aumentos que podem variar de 5x a 64X. Ainda segundo Fernandes (2013), através das análises macrográficas e das análises micrográficas é possível a determinação de diversas características do material, inclusive a determinação das causas de fraturas, desgastes prematuros e outros tipos de falhas. 


\section{I METODOLOGIA}

\subsection{Ensaio Metalográfico}

\subsubsection{Ensaio Macroscópico}

Para realizar a análise metalográfica macrográfica, seguiu-se as seguintes etapas, realizou-se o corte do corpo de prova do aço AISI 1020. Em seguida, adicionou-se a amostra no molde com resina, onde ficou durante 72 horas para secar. Após, a secagem a peça foi lixada a mão com lixas d'agua respectivamente nas seguintes granulometrias: 120, 220, 320, 600, 1200 e 1500 mesh, lixando até restar somente os riscos da última lixa utilizada, como mostra as Figuras 4 e 5.

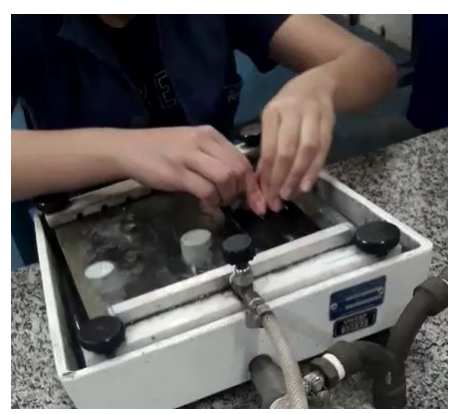

Figura 4: Processo para tirar impurezas através de lixas.

Fonte: Autora, 2018.

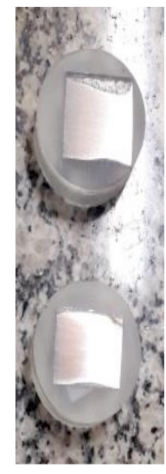

Figura 5: Amostras após lixadas.

Fonte: Autora, 2018.

Usando a máquina Politriz, modelo DP-10 - marca Struers, fez-se o polimento da amostra. E para isto, ajustou-se a vazão da água, adicionou-se o abrasivo alumina; e com as duas mãos foi segurado levemente a peça sobre o pano de polimento até que a superfície ficasse sem nenhum tipo de ranhura, mostrado na Figura 6. Para que a amostra, pudesse ser analisada microscopicamente, fez-se o ataque químico da mesma, utilizando Nital a 2\% (2\% de ácido Nítrico e $98 \%$ de álcool etílico), como mostra a Figura 7. Após o ataque químico limpou-se a amostra para remover os resíduos do processo, através da lavagem com água e álcool, sendo em seguida, a mesma seca através do jato de ar quente, proveniente de um secador. 


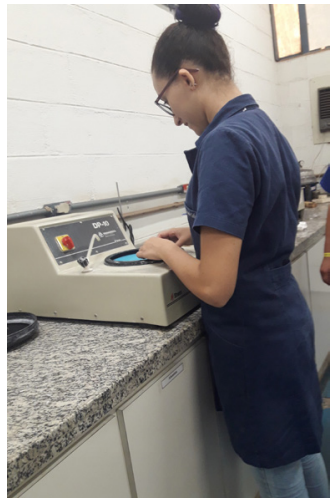

Figura 6: Polimento das amostras Fonte: Autora, 2018.

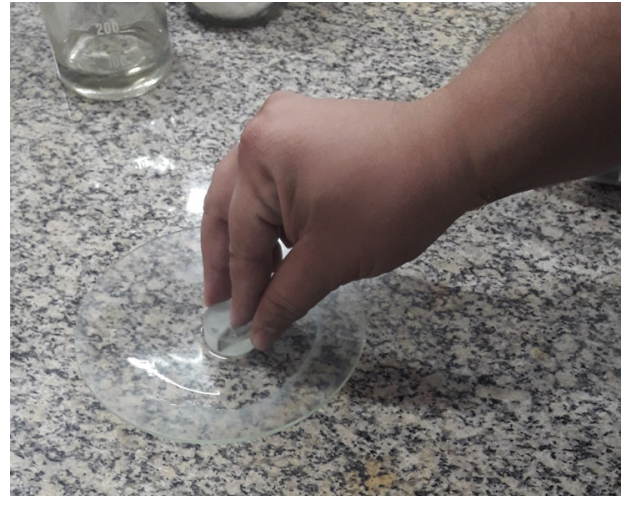

Figura 7: Realização do ataque químico. Fonte: Autora, 2018.

Com a amostra devidamente preparada, pode-se realizar a análise macroscópica, por meio do microscópio modelo Stereo Discovery.V8 - marca ZEISS com resolução da lente de 20x, mostrado na Figura 8.

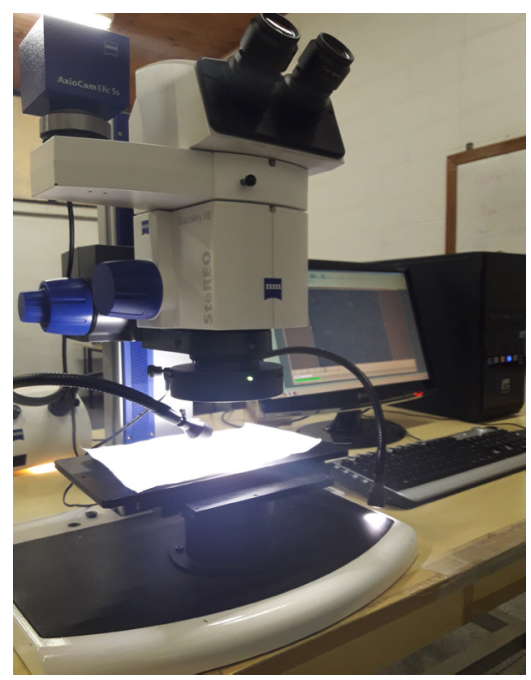

Figura 8: Análise macroscópica.

Fonte: Autora, 2018.

\subsubsection{Ensaio Microscópico}

Para realizar a análise metalográfica micrográfica, seguiu-se as etapas do processo de análise metalográfica macrográfica, descritos no tópico 2.3.1, diferenciando-se no microscópio utilizado modelo TNM 07T PL - marca OPTON, como mostra a Figura 9. 


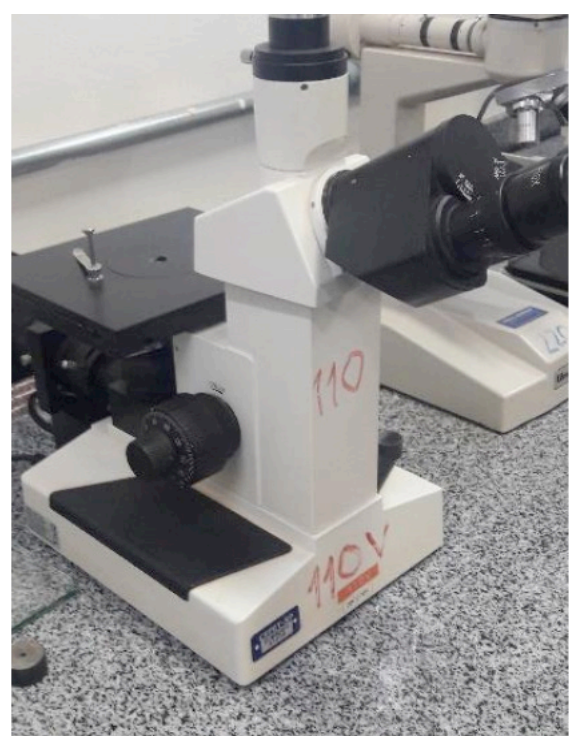

Figura 9: Análise Microscópica.

Fonte: Autora, 2019.

\subsection{Ensaio De Dureza}

Para determinar as propriedades através do ensaio de dureza, foram utilizadas 2 chapas finas aço AISI 1020 após ensaio de tração, sendo que para atingir um bom resultado foram realizadas 15 coletas de dados por amostra, totalizando 30 ensaios. Sendo que os mesmos foram divididos pelo tipo de processo de laminação.

Para a efetuação do ensaio utilizou-se um durômetro da marca Pantec, como mostra a Figura 10, de precisão e escolhida a modalidade Rockwell para interpretação das medidas convencionadas a norma NBR NM 461-1. De acordo com as características e aplicações do material em estudo seleciona-se a escala $B$ com um penetrador do tipo esfera de $1,59 \mathrm{~mm}(1 / 16$ ") e uma carga para aplicação de 100 kgf; sendo que esta configuração é utilizada para aços não temperados, ferros fundidos e algumas ligas não ferrosas.

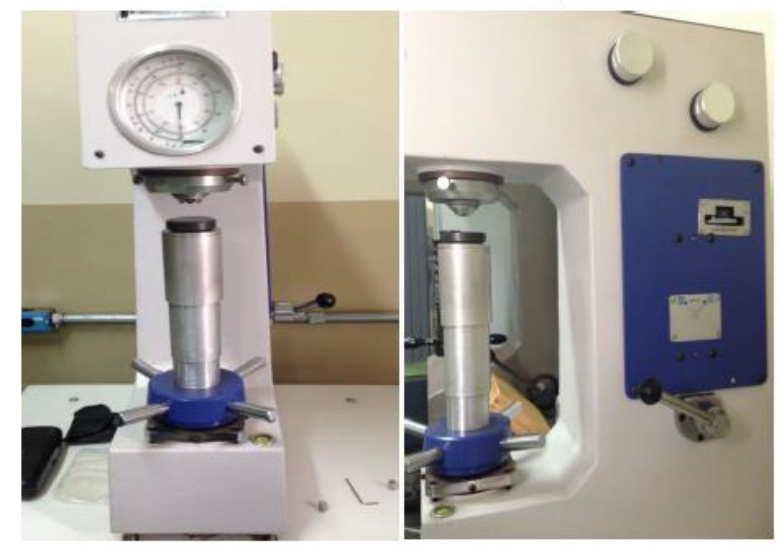

Figura 10: Durômetro para realização do ensaio.

Fonte: Autora, 2019. 


\section{I RESULTADOS E DISCUSSÃO}

Buscou se analisar a diferença do tipo de laminação na chapa, onde essa diferença acontece na microestrutura do material que pode ser comparada com os números obtidos, já que a diferença numérica do processo de laminação é o que se deseja obter nesse ensaio.

\subsection{Ensaio Metalográfico}

No ensaio metalográfico, percebe-se que dependendo da forma como se faz as etapas da micrografia, obtém-se um resultado diferente.

No resultado da macroscopia, percebe-se que as fases de cor escura (carbono) aparecem em menor tamanho, onde na Figura 12, consegue-se visualizar os contornos de grão, com linhas finas formando figuras disformes. Já na Figura 11 tais linhas não podem ser vistas com clareza, demonstrando que esta não foi atacada de forma correta. Para resolver este problema a amostra deveria ser atacada quimicamente por um tempo superior.

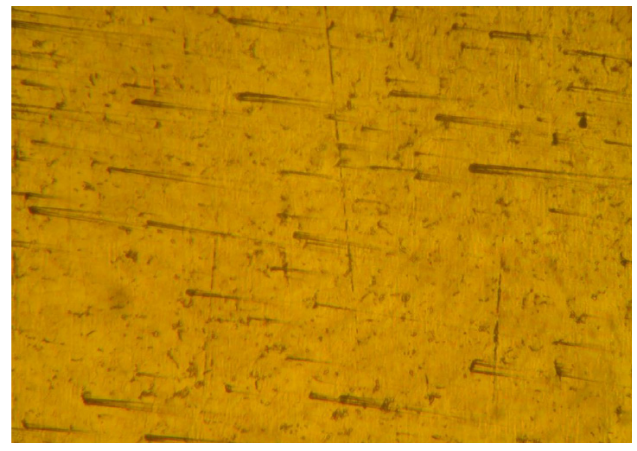

Figura 11: Chapa Laminada a Frio após ataque com zoom de 20x.

Fonte: Autora, 2019.

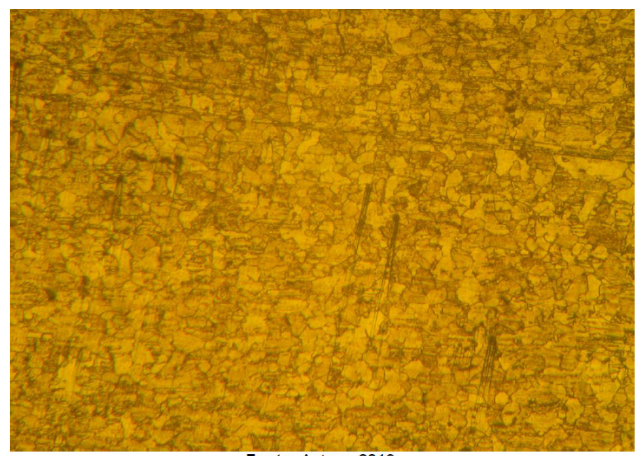

Figura 12: Chapa Laminada a Quente após ataque com zoom de 20x.

Fonte: Autora, 2019.

$\mathrm{Na}$ microscopia, visualizou-se a diferença da distribuição dos grãos entre a chapa fria e a chapa quente, como mostra as Figura 13 e 14, sendo possível perceber que na chapa laminada a quente os grãos por terem um crescimento acarreta numa concentração dos componentes (ferro e carbono). 


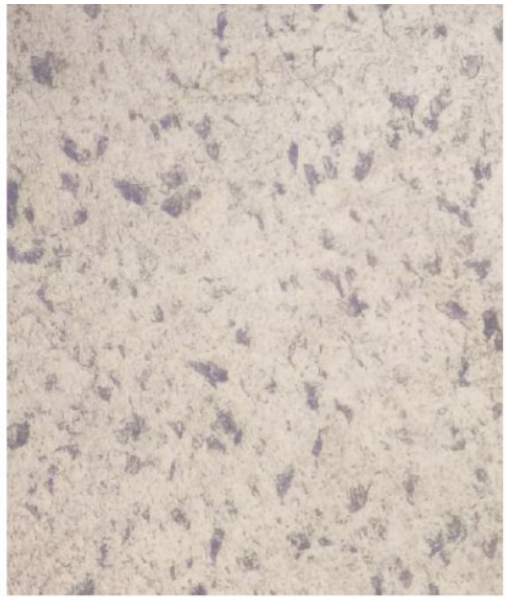

Figura 13: Microscopia da Chapa laminada a Quente, zoom 100x.

Fonte: Autora, 2019

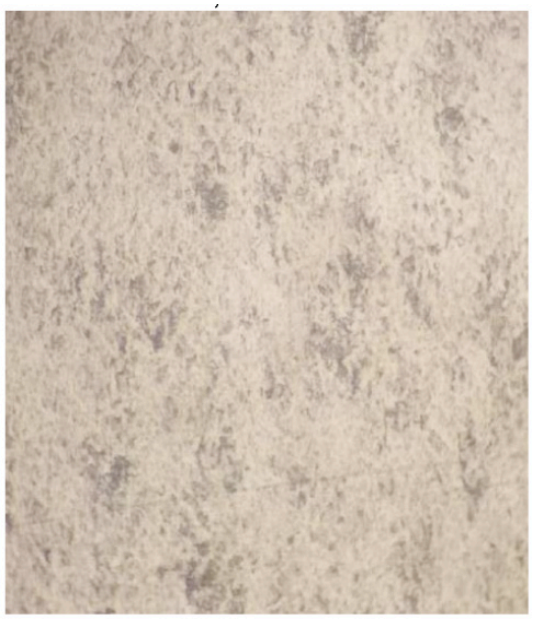

Figura 14: Microscopia da Chapa laminada a Frio, zoom 100x.

Fonte: Autora, 2019.

Na Figura 15, visualiza-se pouco os contornos de grãos, devido ao processo de preparação das amostras. Mas se relacionarmos as Figuras 11, 12, 13 e 14, percebese que nas chapas que foram laminadas a quente consegue-se ver claramente as linhas dos contornos de grão, devido a temperatura que a chapa estava e pelo fato da chapa quando laminadas a frio tenderem ao encruamento, ou seja, ficam mais duras e resistentes à medida que sofre a deformação durante a laminação.

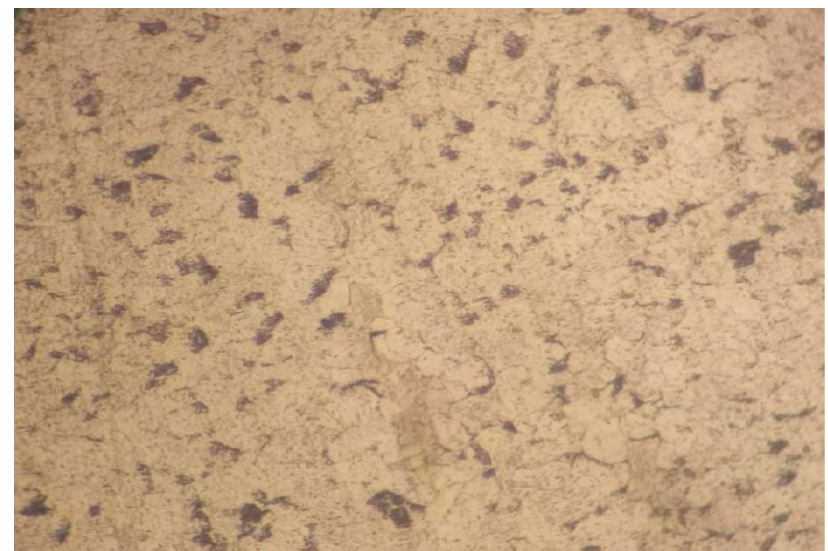

Figura 15: Microscopia da Chapa laminada a Quente, zoom 100x (diminuição da luz). Fonte: Autora, 2019.

\subsection{Ensaio De Dureza}

Após realização do ensaio nas partes da chapa que não houve deformação ou ter sido afetada pela garra da máquina de tração, como mostra as Figuras $16 \mathrm{e}$ 17, buscou-se verificar a diferença da maleabilidade do aço através do ensaio de dureza, onde chegou-se aos valores descritos na Tabela 2. 


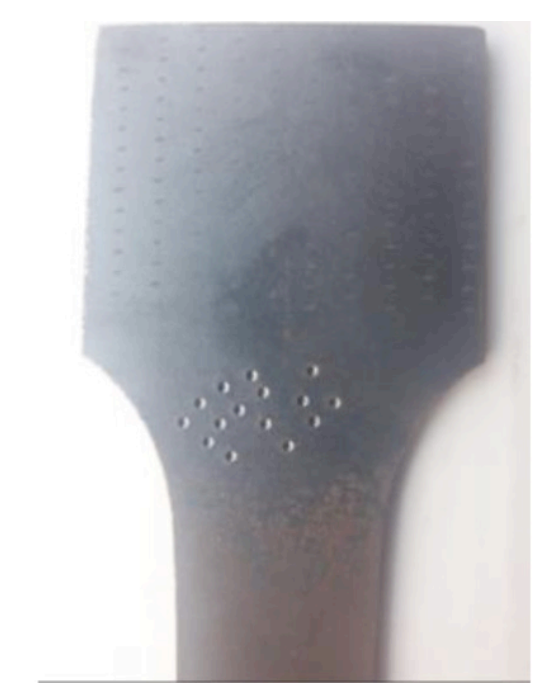

Figura 16: Ensaio feito na Chapa Laminada a Quente.

Fonte: Autora, 2019.

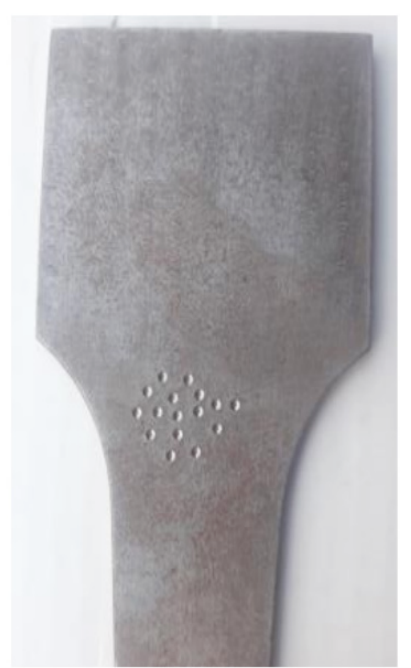

Figura 17: Ensaio feito na Chapa Laminada a Frio. Fonte: Autora, 2019.

Pontos nas
Amostras
1
2
3
4
5
6
7
8
9
10
11
12
13
14
15
Média
Desvio Padrão

Chapa Laminada a Quente

Chapa Laminada a Frio

Dureza (HRB)

33

29

28

23

23

24,5

25,5

26

28

25,5

25

24,5

33

27

30,5

27,03

3,21
Dureza (HRB)

45,5

41

47

43,5

44

48,5

39,5

39,5

36,5

38

38,5

37

39

33

31

40,1

4,93

Tabela 2: Resultados Ensaio de Dureza.

Fonte: Autora, 2019.

Com o resultado da média, chega-se ao fato de que ambas as chapas ficaram entre o range de 20 - 80 HBR descrito pela norma, como mostra a Tabela 2 e Figura 18. Percebe-se que o processo de laminação a frio além de dar acabamento superficial também aumenta a dureza do material, totalmente inverso do processo de laminação a quente. Onde percebemos claramente que a variação de uma chapa para outra é pequena, sendo que o último ponto é bem próximo. Mas se compararmos em relação à média percebemos que essa variação se torna alta, causados devido a forma como foi realizado o processo de conformação, a microestrutura do material, entre outras variações relacionadas ao processo de fabricação das chapas. 


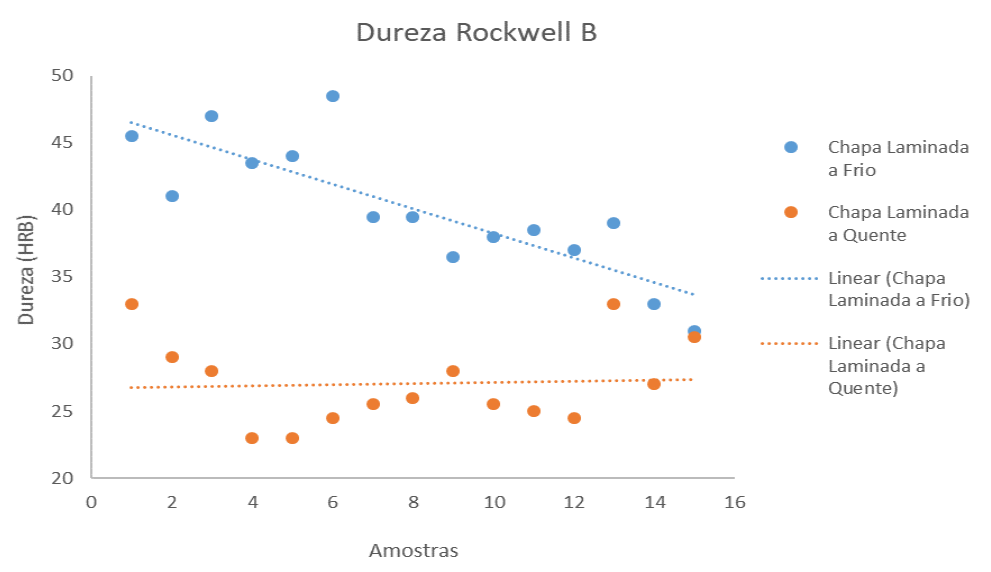

Figura 18:Gráfico comparativo das Durezas.

Fonte: Autora, 2019.

Portanto, mesmo com essas variações cada produto que utilizará essas chapas dependerá da escolha do processo de fabricação das mesmas, sendo as chapas laminadas a quente destinadas a produtos como tubos metálicos, rodas, autopeças, entre outros; já as chapas laminadas a frio destinadas para eletrodomésticos, automóveis, esquadrias, entre outros.

\section{I CONSIDERAÇÕES FINAIS}

A partir do ensaio de dureza percebe-se que seu valor não se altera além do limite de tolerância descrito na norma, mas sim com o processo de laminação. Desse modo, a variação de dureza das chapas laminadas a frio tende-se a ser superior do que as laminadas a quente, o que ajuda a definir qual melhor processo pra determinado produto, pois de acordo com o destino desse produto saberá se 0 mesmo terá que ter baixa ou alta resistência.

Com o ensaio metalográfico, percebe-se que a microestrutura do aço se altera mediante a temperatura do processo e de acordo com o sentido da laminação, afetando propriedades como resistência mecânica, dureza, entre outros, validando a concentração das fases descritas na teoria.

Mediante análise dos resultados atingidos a partir da realização dos ensaios mecânicos e macroestrutural, conclui-se que a temperatura durante o processo de laminação das chapas altera algumas propriedades mecânicas do material, tais como: o limite de escoamento, a tensão de resistência, dureza, ainda que outras variáveis possam ser utilizadas para se obter um melhor resultado referente aos ensaios, como a utilização de tratamentos térmicos, outros ensaios, entre outros aspectos. 


\section{REFERENCIAS}

ASSOCIAÇÃO BRASILEIRA DE NORMAS TÉCNICAS. NBR NM 146 -1: Materiais Metálicos - Dureza Rockwell. Rio de Janeiro, 1998 1- 13 p.

COLPAERT, H. Metalografia dos produtos comuns. 4. ed. revista e atualizada por COSTA E SILVA, André Luiz V. São Paulo: Editora Blucher, 2008.

EMPRESA DE PESQUISA ENERGÉTICA. Energia no Setor Siderúrgico Brasileiro 2009 - Ano base: 2008. Rio de Janeiro, RJ: EPE, 2009. (Estudos Setoriais). Disponível em:

<http://www.epe.gov.br/mercado/Documents/S\%C3\%A9rie\%20Estudos\%20de\%20

Energia/20090430_2.pdf >. Acesso em: 9 ago. 2019.

ETPC (Escola Técnica Pandiá Calógeras). Materiais, Processos de Fabricação e Ensaios, 2012. Apostila do Curso Técnico em Eletromecânica. Volta Redonda.

FERNANDES, R. O que é Metalografia (com Referencias Normativas), 2013. Disponível em: < http://qualitecr.blogspot.com/2013/03/o-que-e-metalografia.html>. Acesso em: 7 ago. 2019.

GARCIA, A.; SPIM, J.A.; SANTOS, C.A. Ensaio dos Materiais, Rio de Janeiro: LTC, 2012. 2 ed.

LUZ, G. Aço SAE 1020 Propriedades Mecânicas e Composição Química. Blog Materiais, [s. I], 2017. Disponível em: https://www.materiais.gelsonluz.com/2017/10/aco-sae-1020-propriedadesmecanicas.html. Acesso em: 09 ago. 2019. 


\section{ANÁLISE DAS JUNTAS SOLDADAS NA UNIÃO DA ESTRUTURA DO VEÍCULO BAJA SAE}

Data de aceite: 05/06/2020

Data de submissão: 02/06/2020

Henrique Ajuz Holzmann Professor na Universidade Tecnológica Federal do Paraná - Campus Guarapuava

Victor Henrique Javara Aluno da Universidade Tecnológica Federal do Paraná - Campus Guarapuava

RESUMO: O campeonato Baja SAE está em crescente visibilidade mundial, com isso a importância das modificações e aprimoramentos torna-se crucial para diferenciar-se. Diversos estudos são realizados em torno do veículo Baja SAE, desses destacam-se estudos de melhorias de projeto, estudos de projeto em si e estudos que comprovam a segurança e qualidade do projeto. A gaiola do veículo Baja é de estrita importância para a segurança do piloto em casos de choques mecânicos do veículo durante as competições. Para a sua fabricação é utilizado o processo de soldagem na união dos tubos, este ocasiona a perda local das propriedades mecânicas do material, fenômeno denominado de Zona Termicamente Afetada (ZTA), tornando de grande importância as análises mecânicas exercidas sobre esta.
Visando comprovar a qualidade da fabricação da gaiola, este trabalho tem como objeto de estudo corpos de prova simulando pontos de união da gaiola a serem verificados através de ensaios mecânicos destrutivos e não destrutivos.

PALAVRAS-CHAVE: Baja. SAE. Soldagem. Ensaios Mecânicos. Gaiola. ZTA.

\section{WELDED JOIN UNION ANALYSIS OF BAJA}

\section{SAE VEHICLE STRUCTURE}

ABSTRACT: The Baja SAE championship is growing day by day all over the world, thus, studies are necessary for modification and upgrading as a differential at engineering. Several improvement studies about Baja SAE vehicle are performed for example studies about design, design improvements and studies that prove safety and quality of the project. The roll cage is extremely important for the safety of the pilot in case of mechanical shocks during competitions. It is used a welding process at the tube joints for the cage manufacturing. This process causes damage of mechanical properties of the material, this phenomenon is called Heat Affected Zone (HAZ). Trying to prove the roll cage manufacturing quality, this term paper has as study object proof bodies for simulation of roll cage joints to be checked 
through destructive and nondestructive mechanical testing.

KEYWORDS: Baja. SAE. Welding. Mechanical Testing. Roll Cage. HAZ.

\section{I INTRODUÇÃO}

A competição Baja SAE teve início em 1976 na Universidade da Carolina do Sul, Estados Unidos, sob a direção do Dr. J.F Stevens. No Brasil as atividades deram início em 1991, sendo que em 1994 o Projeto Baja SAE Brasil foi lançado. No ano seguinte se realizou a primeira competição nacional, em São Paulo. Atualmente a competição é realizada em Piracicaba, interior de São Paulo, no ECPA - Esporte Clube Piracicabano de Automobilismo (BAJA SAE BRASIL, 2020).

O projeto dos Bajas vêm sendo aprimorado não somente para as competições, mas também na área de inovações tecnológicas, trazendo um impacto a sociedade. Exemplos disto são as estratégias desenvolvidas por algumas equipes que ao estudar, identificaram a possibilidade de substituição de materiais buscando uma diminuição de peso, e com isso ganhando aceleração, velocidade e dirigibilidade (PORTAL FATOR BRASIL, 2016).

A estrutura do veículo Baja, Figura 1, é constituída basicamente por tubulação de aço SAE 1018, dobrados e ligados por meio de juntas soldadas (conforme regulamentação da competição Baja SAE Brasil). O chassi do veículo Baja tem o intuito de proporcionar segurança ao piloto, sendo restrita a presença de cantos vivos ou falhas nítidas, os quais serão avaliados pelos juízes da competição. 0 veículo deverá ser capaz de receber todos seus subsistemas, como pedais, volante, suspensão e eixos. Antes da fabricação, realiza-se um projeto da estrutura, obedecendo as normas vigentes na competição.
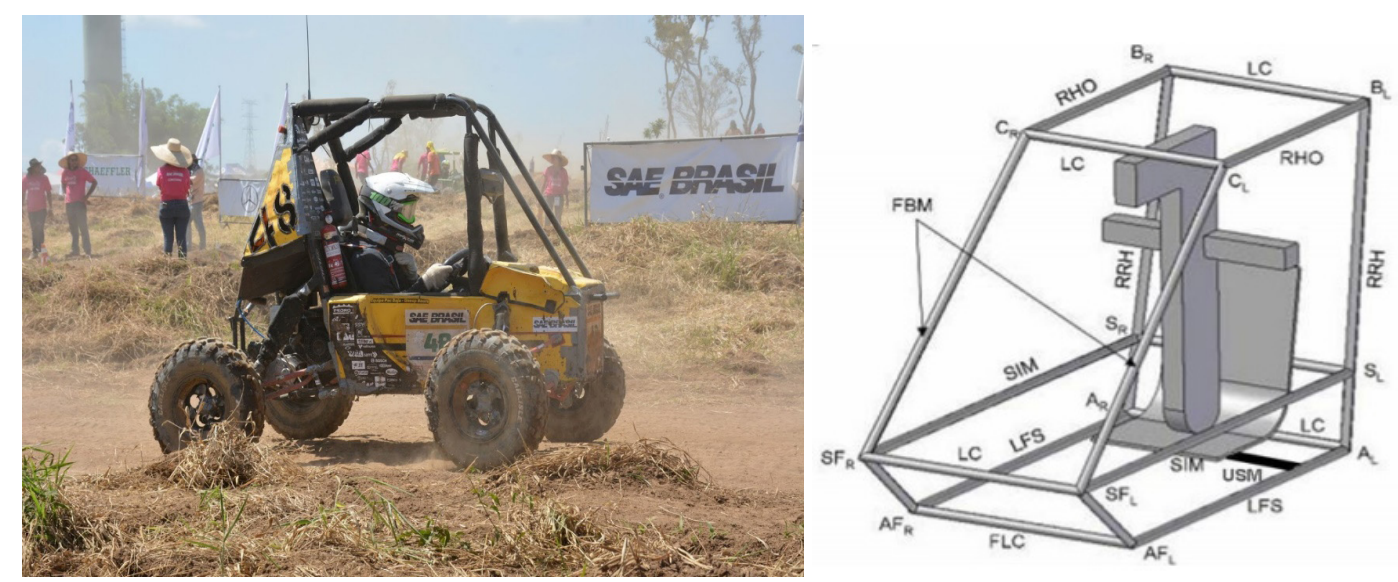

Figura 3 - Baja SAE e gaiola do regulamento.

Fonte: Regulamento Baja SAE Brasil (2020). 
Como o método de soldagem da estrutura do veículo não é especificado na norma, abre-se espaço para que seja trabalhado com intuito de buscar uma otimização do mesmo, tanto na parte econômica, quanto na parte estrutural. $O$ processo de soldagem comumente empregado na estrutura BAJA, gira em torno da solda através de eletrodo revestido, MIG/MAG (Metal Inert Gas, Metal Active Gas) ou TIG (Tungsten Inert Gas). Estudar a junta gerada se torna de grande importância, visto que nesta região ocorre um acumulo de tensões e se torna pontos propícios ao início de falhas.

Esse estudo é essencial para que possa comprovar a eficiência das soluções empregadas no projeto, e através da realização de ensaios e caracterizações mecânicas obter os resultados e gerar laudos a fim de comprovação. Assim o trabalho apresentado visa analisar a junta soldada empregada na união de tubos de Aço SAE 1020 e verificar a viabilidade de uso na fabricação da estrutura do veículo Baja.

\section{I METODOLOGIA}

De acordo com o regulamento Baja SAE Brasil (2020), existe a necessidade de especificação dos materiais e processo utilizados na fabricação da estrutura "gaiola" do veículo Baja. Dentro deste contexto, o material a ser utilizado possui equivalência mecânica ao Aço SAE 1018. Para a fabricação deste veículo Baja, foram selecionadas barras de Aço SAE 1020 trefilado com diâmetros de uma polegada.

Os tubos de aço foram devidamente cortados angularmente em $60^{\circ}, 90^{\circ}$ e $180^{\circ}$ de defasagem em relação ao eixo paralelo ao tubo, a fim de se produzir as situações reais utilizadas na fabricação da estrutura. Foram fabricados 3 corpos de prova em cada uma das angulações, a fim de verificar a repetitividade dos resultados.

A união dos materiais foi realizada através do processo de solda MAG, no laboratório da Universidade Tecnológica Federal do Paraná, Câmpus Guarapuava. Para o processo de soldagem foi utilizada a máquina de solda modelo Hank 335 da marca SUMIG. O gás de proteção utilizado foi a mistura 75\% Argônio e 25\% de Oxigênio e o arame foi AWS A5.18 ER70S-6, composto por C (0,07-0,15 \%); Mn $(1,40-1,80 \%)$; Si $(0,80-1,15 \%)$; S $(\leq 0,035 \%)$ e P $(\leq 0,025 \%)$ segundo a literatura ESAB.

Os parâmetros de processo utilizado foram: corrente de soldagem 160 Ampere, tensão de soldagem 20 Volts, velocidade de soldagem 1,5 m/min, velocidade de alimentação do arame de solda 6,5 m/min e vazão do gás de proteção $20 \mathrm{~L} / \mathrm{min}$.

Após a realização do processo de soldagem as amostras foram limpas e 
inspecionadas, inicialmente através de ensaios mecânicos não destrutivos (inspeção visual e líquidos penetrantes) seguidos pelo ensaio de dureza e metalografia.

A inspeção visual foi realizada para identificação de defeitos nítidos nos corpos de prova, sendo os mesmos imediatamente descartado caso positivo de descontinuidades. Já o ensaio por líquidos penetrantes foi realizado de acordo com a norma ABNT NBR 16450:2016.

Para realização do ensaio de dureza foram realizadas demarcações com intervalos de 2 milímetros, a partir da linha de união, essas demarcações percorreram de - 6 à 6 (range da demarcação), varrendo em torno de 25 milímetros. Na realização do ensaio de dureza foi utilizado um durômetro de bancada Digimess Rockwell B Normal, utilizando o edentador esférico de 1/16" (polegadas) com carga inicial de $10 \mathrm{kgf}$ e carga principal de $100 \mathrm{kgf}$.

$\mathrm{Na}$ sequência as amostras foram cortadas (cortadora metalográfica CM40/60) e embutidas (prensa embutidora metalográfica manual EM30D) a fim de realizar o ensaio metalografico, buscou-se evidenciar a região do cordão de solda (união), bem como da ZTA e metal base.

As amostras embutidas forma preparada conforme ABNT NBR 13284:1995, para o lixamento e polimento foi utilizada a politriz lixadeira metalográfica PL02, na sequência a superfície das amostras foi atacada com o reagente Nital a $3 \%$, pelo período de 10 segundos.

Com o processo de preparação da amostra concluído, as amostras foram encaminhadas ao microscópio óptico da marca Olympus e modelo BX521 para a análise metalografica e em seguida realizado a análise dos resultados obtidos.

\section{I RESULTADOS E DISCUSSÕES}

Para validação do material, norma vigente da competição Baja SAE Brasil, é exigida a utilização de aços com teor de carbono de pelo menos $0,18 \%$, com diâmetros externo de tubo de 25,4 milímetros com espessura de parede de 3,05 milímetros. Para fabricação utilizando materiais diferentes deste, a norma exige cálculos comprovando valores proporcionais de resistência e rigidez à flexão aos do aço $1018\left(\mathrm{~S}_{\mathrm{y}}=370 \mathrm{MPa}\right.$ e $\left.\mathrm{E}=205 \mathrm{GPa}\right)$.

De acordo com o fabricante o material selecionado para fabricação da estrutura, Aço SAE 1020 trefilado, possui as propriedades apresentadas na Tabela 1. 


\begin{tabular}{lcccccc}
\hline SAE & $\begin{array}{c}\text { Limite de } \\
\text { Escoamento } \\
(\mathbf{M P a})\end{array}$ & $\begin{array}{c}\mathrm{E} \\
\mathbf{( D e f o r m a c ̧ a ̃ o )} \\
\left(\mathbf{2}^{\star}\right) \%\end{array}$ & $\begin{array}{c}\text { Dureza } \\
\text { Brinell } \\
\mathbf{( H B )}\end{array}$ & $\begin{array}{c}\text { Limite de } \\
\text { Resistência } \\
\text { à Tração }\end{array}$ & $\begin{array}{c}\text { Carbono (\%) } \\
\text { Manganês } \\
\mathbf{( \% )}\end{array}$ \\
\hline 1018 & 370 & 15 & 126 & 435 & $0,15-0,20$ & $0,60-0,90$ \\
1020 & 350 & 15 & 121 & 417,5 & $0,18-0,23$ & $0,30-0,60$ \\
\hline
\end{tabular}

Tabela 1 - Propriedades Mecânicas Estimadas de barras de Aço Trefiladas.

Fonte: <brasil.arcelormittal.com.br>, adaptado.

Para a validação dos tubos utilizados, partiu-se da equação de momento fletor que supostamente deve ser suportado de modo equivalente ou superior pelo aço utilizado em comparação ao exigido pela norma. O momento fletor $\left(M_{t}\right)$ é apresentado na Equação 1, onde $S_{y}$ simboliza o limite de escoamento (MPa), $I_{x}$ o momento de área em relação ao eixo $x$ e $c$ é a distância do eixo à parte mais externa do tubo, onde sofre maiores tensões (NORTON, 2013).

$$
M_{f}=\frac{S_{y} I_{x}}{c}
$$

O momento de área em relação ao eixo x é encontrado a partir da Equação 2, onde o diâmetro externo é representado por $D$ e o diâmetro interno por $d$ (NORTON, 2013).

$$
I_{x}=\frac{\pi}{64}\left(D^{4}-d^{4}\right)
$$

Partindo das equações e dos dados tabelados, encontra-se a espessura mínima para que o Aço SAE 1020 trefilado utilizado no projeto seja valido. Para encontrar a espessura mínima utiliza-se a Equação 3.

$$
d_{\text {máx }} \leq\left(D^{4}-\frac{64}{\pi} \times \frac{1}{\left(S_{y}\right)_{1020}} \times\left(S_{y} \times I_{x}\right)_{1018} \times \frac{c_{1020}}{C_{1018}}\right)^{1 / 4}
$$

Os resultados de $d_{\text {máx }}$ e espessura encontrados são para o aço SAE 1018 (diâmetro mínimo de 19,3 mm e espessura mínima de parede de 3,05 mm) já para o aço SAE 1020 (diâmetro mínimo de 18,74 mm e espessura mínima de parede de $3,33 \mathrm{~mm})$.

A análise feita é fundamental para a validação do material utilizado na fabricação da estrutura, e possibilita a utilização do material da estrutura na competição Baja SAE conforme dita a norma de segurança exigida. 


\subsection{Análise geométrica do cordão de solda}

Segundo Pessoa et. al. (2010), a geometria do cordão de solda visa analisar a qualidade da junta soldada, permitindo que a junta seja preenchida com o mínimo de defeitos, a Figura 2 apresenta a as principais medidas necessárias a avaliação.

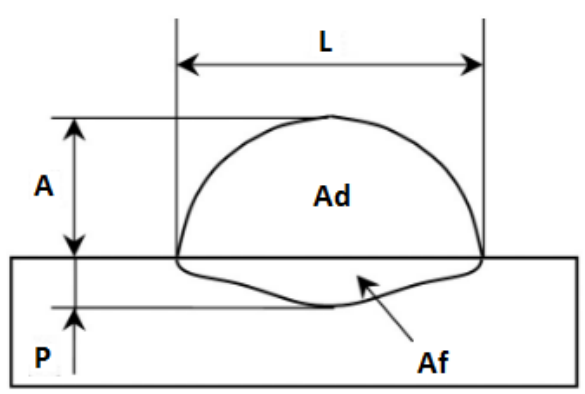

L - Largura

A - Altura

P - Penetração

Ad - Área depositada do cordão

Af - Área fundida do metal de base

Figura 2 - Perfil geométrico de um cordão de solda Fonte: Pessoa et al (2010), adaptado.

A partir da análise das amostras, pode-se obter os valore apresentados na Tabela 2, comprova o alto valor resultante da diluição encontrado por meio de cálculos, visto que à área de reforço é pequena e a penetração da solda atingiu toda a espessura comprovando uma qualidade na união soldada e atendendo aos requisitos exigidos na norma.

\begin{tabular}{ccccccc}
\hline Amostra & $\mathbf{L}(\mathbf{m m})$ & $\mathbf{A}(\mathbf{m m})$ & $\mathbf{P}(\mathbf{m m})$ & $\mathbf{A d}\left(\mathbf{m m}^{2}\right)$ & $\mathbf{A f}\left(\mathbf{m m}^{2}\right)$ & $\mathbf{D}(\%)$ \\
\hline $60^{\circ}$ & 7,3 & 0,8 & 2,8 & 6,2 & 7,3 & 54,07 \\
$90^{\circ}$ & 6,9 & 1,1 & 3,1 & 6,8 & 7,5 & 52,04 \\
$180^{\circ}$ & 8,5 & 0,6 & 3,3 & 5,0 & 8,8 & 63,79 \\
\hline
\end{tabular}

Tabela 2 - Morfologia doa cordões de solda

\subsection{Ensaio por Líquidos Penetrantes}

Com os ensaios por líquidos penetrantes foi possível verificar a presença de respingos, poros e mordeduras nos diferentes corpos de prova.

Enquanto na união linear dos tubos observou a presença de pouca porosidade e nenhuma mordedura evidenciada, os corpos unidos com angulações apresentaram mordeduras, respingos e porosidades, principalmente nos tubos unidos em $90^{\circ}$, ilustrados na Figura 3. Nesses ocorreram maiores imperfeições pela dificuldade da aplicação do processo de soldagem, por exigir maior área de preenchimentos e por eventuais tolerâncias mal dimensionadas no corte "boca de lobo". 


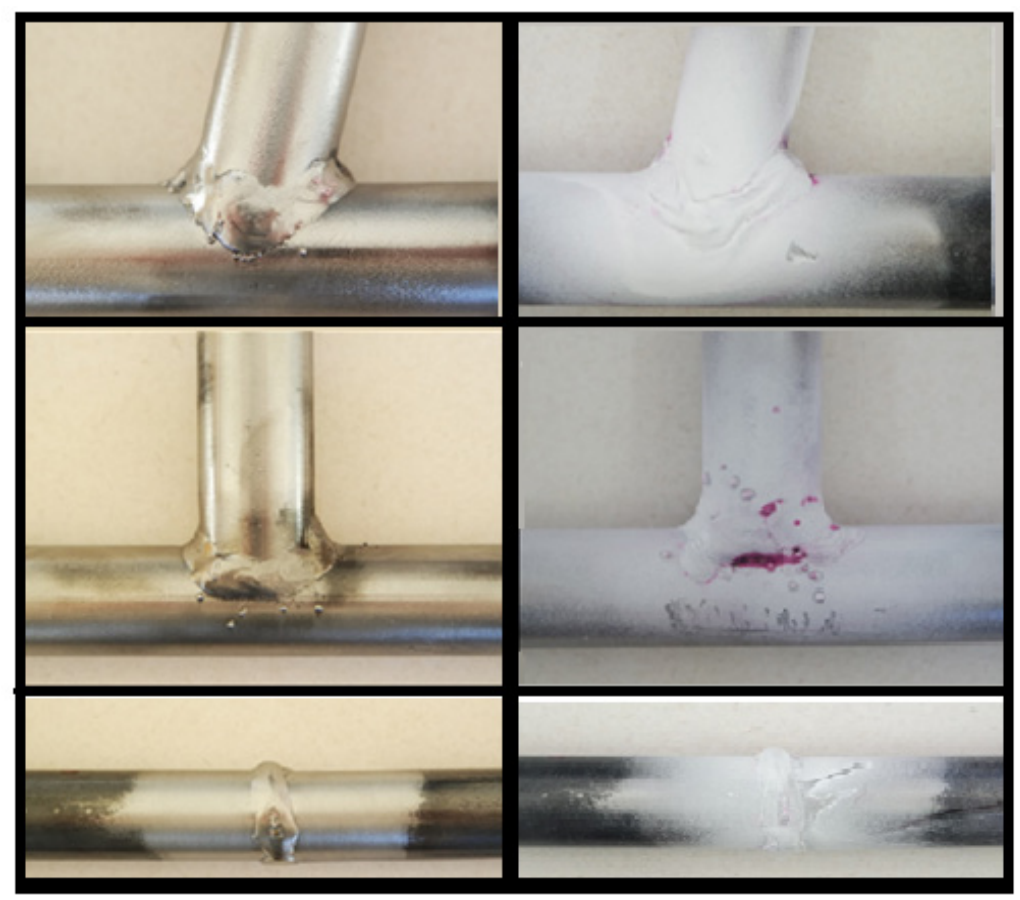

Figura 3 - Análise com líquidos penetrantes após aplicação do revelador.

\subsubsection{Ensaio de Dureza}

Os valores obtidos a partir do ensaio de dureza Rockwell foram inseridos no Gráfico 1 contrastando com a faixa de dureza comum do aço SAE 1020 encontrado nas literaturas da Arcelor Mittal. A faixa de dureza comum do aço SAE 1020 foi encontrada em forma de dureza Brinell (HB) e então convertida para os valores em dureza Rockwell B (HRB) a partir da tabela que pode ser encontrada no endereço virtual da Steel Express. Os valores encontrados com base nos ensaios práticos em contraste com a os valores de dureza padrão do aço SAE 1020 trefilado são ilustrados pela Gráfico 1.

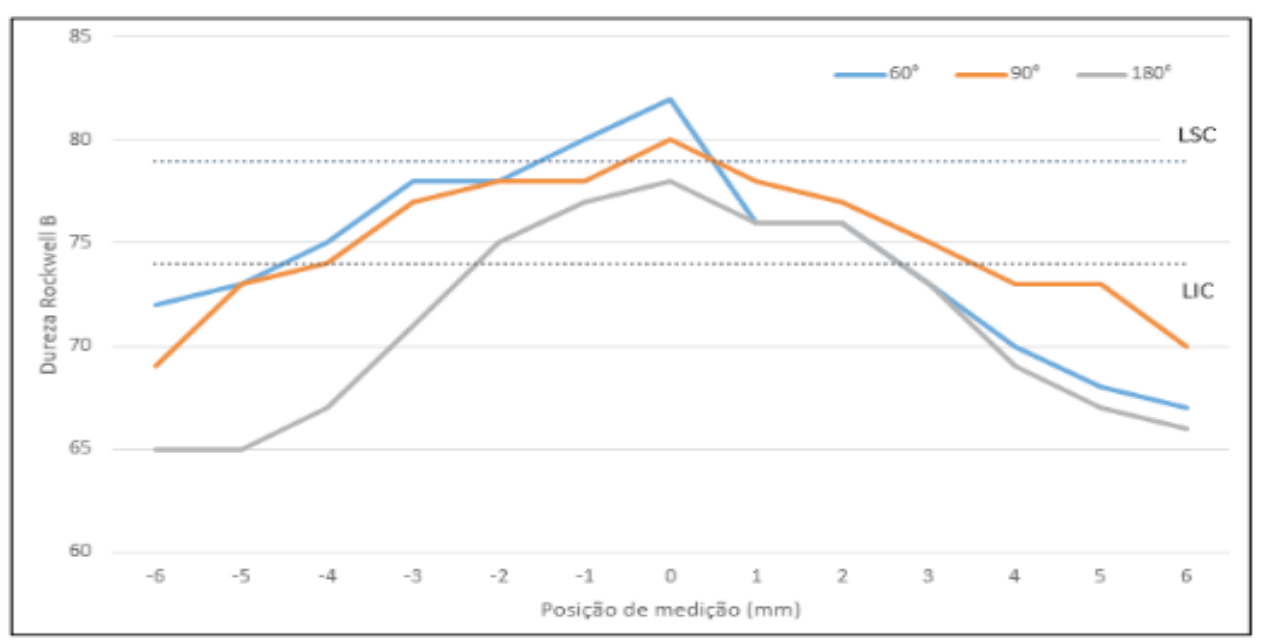

Gráfico 1 - Ensaio de dureza realizado no corpos de prova unidos em $60^{\circ}, 90^{\circ}$ e $180^{\circ} \mathrm{em}$ contraste à faixa dureza padrão do Aço SAE 1020 trefilado. 
Nota-se que na posição zero é evidenciada uma dureza elevada em relação a outras posições. De acordo com Modenesi (2012), o processo de soldagem MAG apresenta temperatura de processo mais baixa em relação a outros processos, logo o metal de solda apresenta uma densidade de deslocação elevada, ocasionando um aumento no limite de escoamento, caracterizando a zona fundida como mais resistente que o metal base.

Em contrapartida a baixa dureza na zona termicamente afetada é notada, resultado do aumento dos grãos causados pelo recozimento. O recozimento resulta no alivio das tensões locais causando a perda de resistência mecânica.

\subsubsection{Ensaio Metalográfico}

Do ensaio metalográfico realizado na amostra retirada do metal base $(\mathrm{MB})$ do corpo de prova de aço SAE 1020 foi obtido fotografias com a ampliação de $20 \mathrm{X}$. Através da análise microscópica da amostra, observou-se presente a fases ferrita e perlita, identificados na Figura 4.

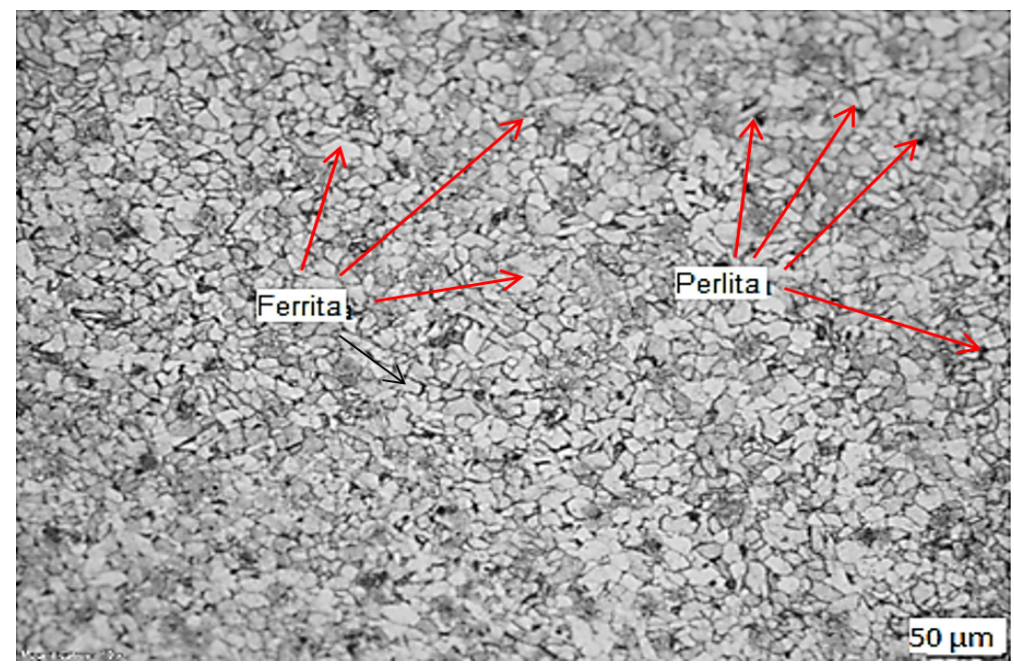

Figura 4 - Micrografia com ampliação de $20 \mathrm{X}$ do Metal Base.

Segundo Callister (2007), Colpaert (2008), a ferrita é definida como a solução sólida do carbono em ferro alfa enquanto a perlita se caracteriza pela presença de grãos chamados de colônias, e com camadas internas orientadas, sendo as camadas claras e mais grossas representadas pela ferrita e as lamelas finas pela cementita.

Da Figura 5, pode-se observar a amostra retirada do cordão de solda com ampliação de $5 \mathrm{X}$, sendo essas fotografias concentradas inteiramente no cordão de solda não contemplando a ZTA. 


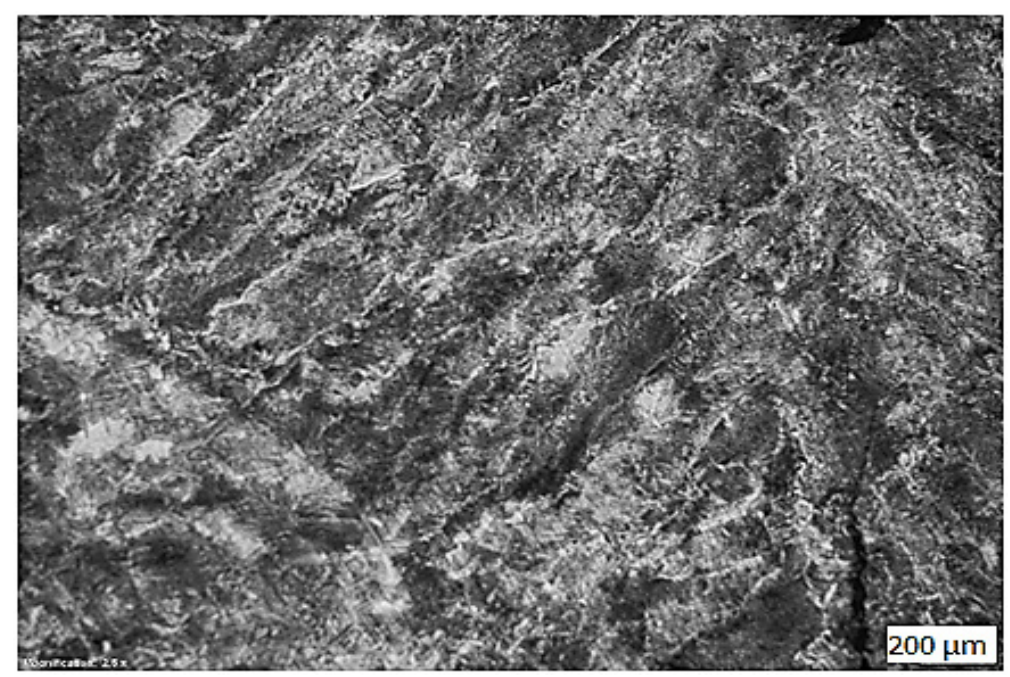

Figura 5 - Micrografia com ampliação de $5 \mathrm{X}$ do cordão de solda.

Para uma análise mais precisa temos a Figura 6 mostra o cordão de solda com ampliação de $20 \mathrm{X}$.

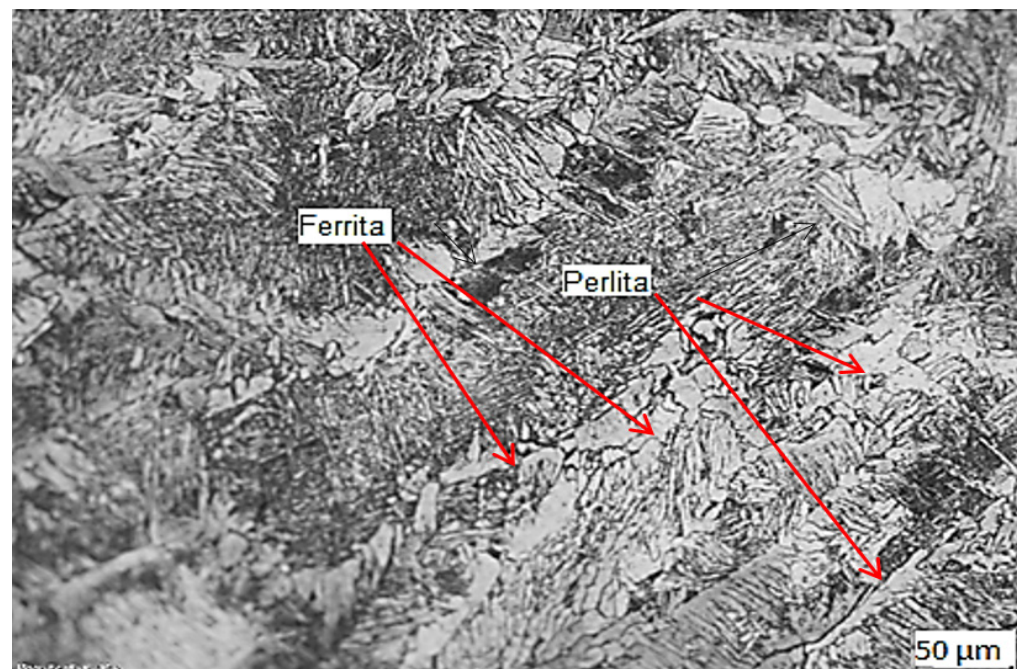

Figura 6 - Micrografia com ampliação de 20 X do cordão de solda.

Como cordão de solda de material AWS A5 18 ER70S-6 forma uma microestrutura basicamente de ferrita e perlita quando fundido, se equivale ao Aço SAE 1020, diferenciando-se apenas por apresentar uma granulometria grosseira resultante da elevada energia térmica aplicada durante o processo de soldagem.

A Figura 7 ilustra a micrografia da ZTA (zona termicamente afetada) com ampliação de $5 \mathrm{X}$. 


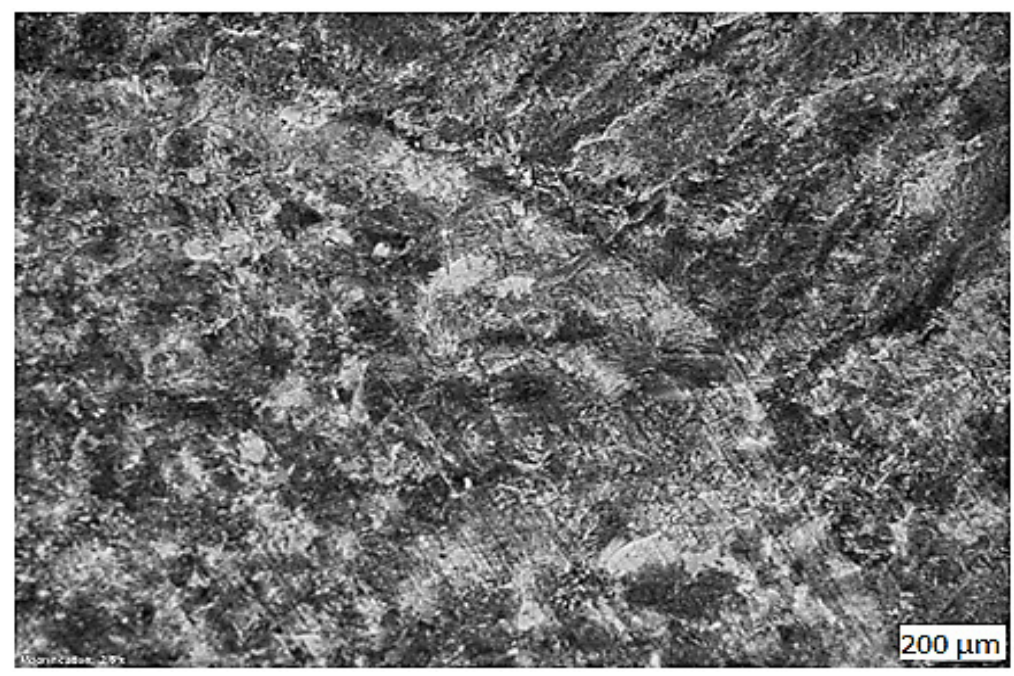

Figura 7 - Micrografia com ampliação de $5 \mathrm{X}$ da Zona Termicamente Afetada.

Para obter uma análise mais precisa sobre o tamanho de grãos comparado com os grãos obtidos da amostra do metal base temos a análise metalográfica da ZTA (zona termicamente afetada) com aumento $20 \mathrm{X}$, ilustrado pela Figura 8 .

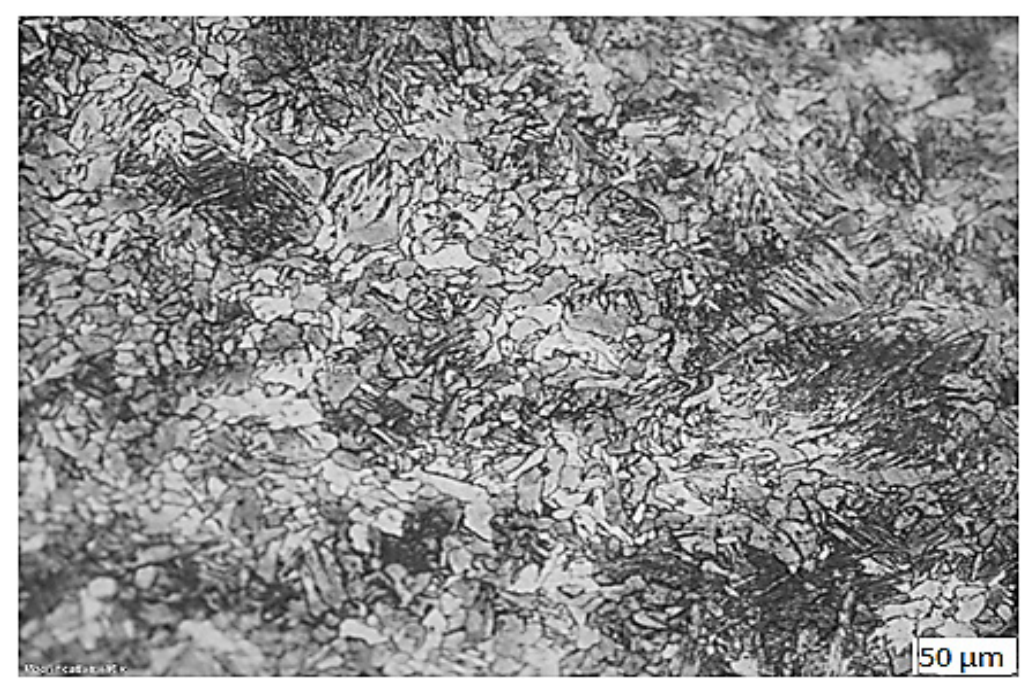

Figura 8 - Micrografia com ampliação de $20 \mathrm{X}$ da Zona Termicamente Afetada.

Em comparação da Figura 28 (ZTA 20 X) com a Figura 24 (MB 20 X), nota-se o crescimento dos grãos na ZTA (zona termicamente afetada), ocorrente devido ao fenômeno de recozimento dos grãos (ESAB, 2005).

\section{I CONCLUSÕES}

A proposta em realizar a união entre tubos com diferentes angulações foi abrangente, visto que representa situações reais. Os corpos de prova devidamente trabalhados foram expostos a ensaios e análises mecânicas garantindo e quantificando suas propriedades mecânicas pós processos de soldagens, 
comprovando a segurança da estrutura em esforços submetidos em competições.

Analisou-se a partir dos ensaios não destrutivos a qualidade da solda, por se ter utilizado a soldagem MAG obteve uma solda limpa possuindo em apenas alguns corpos de prova a presença de respingos que puderam ser observados no ensaio visual. O corpo de prova que obteve maior incidência de porosidade e mordeduras se deu pela dificuldade do processo de soldagem, por se tratar de uma angulação inclinada e podendo ser resultado de um corte "boca de lobo" dimensionado com tolerâncias flexíveis. Em contra partida na união dos tubos pela extremidade houve a presença quase insignificante de porosidade analisada somente a partir do ensaio com líquidos penetrantes, reiterando a qualidade do processo de soldagem.

O ensaio destrutivo de metalografia demonstrou o aumento dos grãos na zona termicamente afetada, o que já era esperado, causando a perca de propriedades mecânicas comprovadas pelo ensaio de dureza. Da metalografia observou que o arame de solda (AWS A5 18 ER70S-6) utilizado favoreceu a formação de ferrita e perlita, semelhante ao encontrado no metal base (Aço SAE 1020).

A geometria do cordão de solda auxiliou a obtenção de valores de diluição, esses os quais foram notavelmente positivos comparados aos valores médios aproximados desse processo de soldagem, reintegrando a boa qualidade e boa aceitação ao processo de soldagem MAG com arame AWS A5 18 ER70S-6.

Do ensaio destrutivo de dureza obteve os valores quantitativos de elevado grau de importância do trabalho, este teve por função encontrar a alteração das propriedades mecânicas resultantes do processo de soldagem.

O estudo realizado sobre as propriedades mecânicas do Aço SAE 1020 antes do processo de soldagem obteve resultados com divergências de aproximadamente 4\% em relação ao Aço SAE 1018, e pós processo de soldagem de aproximadamente 9,6\% em relação ao Aço SAE 1018 isento de cordões de solda. Os valores obtidos foram relativamente pequenos, o que torna viável a utilização do Aço SAE 1020 para a fabricação da estrutura do veículo Baja, além disso, deve ser levado em conta o preço mais razoável e a acessibilidade em cidades interioranas quando comparado ao Aço SAE 1018.

\section{REFERÊNCIAS}

ARCELORMITTAL. Guia do aço. Disponível em: <brasil.arcelormittal.com.br> Acesso em: 23 de abril 2020.

BAJA SAE BRASIL. Histórico do Projeto Baja SAE. Disponível em:

<http://portal.saebrasil.org.br/programas-estudantis/baja-sae-brasil> Acesso em: 03 de maio de 2020.

CALLISTER, Jr., W.D. Materials Science and Engineering. 7 ed. New York: John Wiley \& Sons, Inc., 2007. 
COLPAERT, HUBERTUS. Metalografia dos produtos comuns. 4. ed. revista e atualizada. São Paulo: Editora Blucher, 2008.

ESAB. Apostila de Soldagem MIG/MAG. Disponível em: <http://www.esab.com.br/>. Acesso em: 25 de abril 2020.

ESAB. Apostila Metalurgia da Soldagem. Disponível em: <http://www.esab.com.br/>. Acesso em: 20 de abril 2020.

MODENESI, Paulo J.; MARQUES, Paulo V.; SANTOS, Dagoberto B. Introdução à metalurgia da soldagem. Belo Horizonte: UFMG, 2012.

NORTON, Robert L. Projeto de máquinas. Bookman Editora, 2013

PESSOA, A. R. P. et al. Seleção de parâmetros através do método Taguchi para soldagem de revestimento com ligas de níquel pelo processo MIG/MAG. Soldag. insp. (Impr.) 2010, vol.15, n.4, pp. 317-324. ISSN 0104-9224.

PORTAL FATOR BRASIL. Estudantes cariocas e capixabas constroem nove carros para a Competição Baja SAE BRASIL- Petrobras. Disponível em: <http://www.revistafator.com.br>. Acesso em: 21 de abril 2020. 


\section{CAPÍTULO 4}

\section{ANÁLISE EXPERIMENTAL E ANALÍTICA DA INFLUÊNCIA DA RAZÃO W/D EM COMPÓSITO POLIMÉRICO DE POLIÉSTER REFORÇADO POR FIBRAS DE VIDRO/JUTA}

Data de aceite: 05/06/2020

Raphael Siqueira Fontes UFRN - Programa de Pós-graduação em

Engenharia mecânica/PPGEM, Natal - RN/ Brasil e Instituto Federal de Educação, Ciência

e Tecnologia do Rio Grande do Norte (IFRN), Parnamirim, RN, Brasil.

Sérgio Renan Lopes Tinô UFRN Centro de Tecnologia, Campus Universitário, Lagoa Nova, Natal - RN/Brasil, CEP: 59072-970 - PPGEM, PPGCEM e Instituto Federal de Educação Ciências e Tecnologia de Goiás/IFG

Ana Claudia de Melo Caldas Batista UFRN - Programa de Pós-graduação em Engenharia mecânica/PPGEM, Natal - RN/Brasil e UFERSA- Universidade Federal do Semi-Árido,

Caraúbas -RN, Brazil.

Eve Maria Freire de Aquino UFRN - Programa de Pós-graduação em Engenharia mecânica/PPGEM, Natal - RN/Brasil

RESUMO: A proposta deste trabalho é um estudo envolvendo a resposta mecânica, os modos da fratura, Resistência Residual e a aplicação de modelos de critérios de falha, em um laminado compósito híbrido de matriz polimérica utilizados corpos de provas com e sem a presença de descontinuidade geométrica em sua seção longitudinal (com redução da seção transversal), sob a ação de tração uniaxial. Essa descontinuidade geométrica é caracterizada por furos centrais de diferentes diâmetros. O laminado compósito híbrido foi confeccionado pelo processo hand Lay-up, na forma de placa e composto por matriz poliéster orto-tereftálica reforçada com tecidos bidirecionais de fibras de juta e de fibras de vidro-E. A presença do furo central, independente do diâmetro, influiu de forma danosa, principalmente na resistência última à tração. Quanto ao módulo de elasticidade, por outro lado, a diferença encontrada entre os corpos de prova apresentou-se dentro da faixa da dispersão dos ensaios, mostrando estabilidade com relação à rigidez do laminado. Em relação à variação da razão $w / D$, as resistências residuais diminuíram a medida a mesma foi diminuindo, indicando a maior influência da concentração de tensão w/D igual a quatro, já para as distâncias características $a_{0}$ e $d_{0}$, ambos os critérios PSC e ASC mostraram boa aproximação.

PALAVRAS-CHAVE: Compósitos Poliméricos Híbridos; Furo Central; Resistência Residual; Fratura; Critérios de falha. 
ABSTRACT: The purpose of this work is a study involving the mechanical response, the fracture modes, Residual Strength and the application of failure criteria models, in a hybrid composite laminate of polymeric matrix used specimens with and without the presence of geometric discontinuity in its longitudinal section (with reduction of the cross section), under the action of uniaxial traction. This geometric discontinuity is characterized by central holes of different diameters. The hybrid composite laminate was made by the Hand Lay-up process, in the form of a plate and composed of an ortho-terephthalic polyester matrix reinforced with bidirectional fabrics of jute and E-glass fibers. The presence of the central hole, regardless of the diameter, had a damaging effect, especially on the ultimate tensile strength. As for the modulus of elasticity, on the other hand, the difference found between the specimens was within the dispersion range of the tests, showing stability in relation to the laminate stiffness. Regarding the variation of the w/D ratio, the residual resistances decreased as the measure decreased, indicating the greater influence of the $w / D$ voltage concentration equal to four, for the characteristic distances $a_{0}$ and $d_{0}$, both the PSC and ASC criteria showed good approaching.

KEYWORDS: Hybrid Polymeric Composites; Central Hole; Residual Resistance; Fracture; Failure criteria.

\section{I INTRODUÇÃO}

Os materiais compósitos vêm aumentando sua gama de aplicações devido à utilização do processo de hibridização, que consiste em, segundo Batista et al. (2016), em um processo utilizado para compensar a desvantagem de um constituinte indispensável, podendo adicionar um reforço adicional que forneça melhores propriedades mecânicas ou uma propriedade específica ao compósito a ser fabricado.

Aliado ao processo de hibridização destacam-se os problemas ambientais, que propõem o desenvolvimento de novos materiais compósitos com adição de um reforço biodegradável como, por exemplo, tais como fibras naturais como de baixo custo, sendo uma alternativa compatível com o ambiente quando comparado com as fibras sintéticas (Shahzad, 2011) e vem se tornando popular dia a dia devido à falta de recursos e crescente poluição ambiental (Rahman et al., 2008). Rahmana et al. (2008) e Jawaid e Abdul Khalil (2011), em seus reviews, destacam a publicação de trabalhos de vários autores com fibra natural como reforço em compósitos híbridos utilizando resina termofixa.

As Fibras Naturais são encontradas na natureza e dividem-se em fibras de origem animal, vegetal e mineral. Dentre estas a Juta é uma fibra de caule e se destaca como a principal área de investigação, por apresentar a maior concentração 
de celulose (Sabell Ahmed et al., 2006) e, de acordo com Khan et al., (2009) devido a algumas de suas propriedades como, por exemplo, baixa densidade, alto módulo de tração e baixo alongamento na ruptura, rigidez e resistência específicas comparáveis às da fibra de vidro.

Embora a fibra de Juta seja tradicionalmente utilizada na fabricação de embalagens e outros produtos diversificados, encontra-se disponível em abundância, pois esse seu uso artesanal consome apenas uma pequena parcela de sua produção. Vários trabalhos buscam melhorar a superfície da juta por meio de tratamento, exemplificando pode-se citar o trabalho de Rahman et al., (2008), que utilizou a fibra de Juta como Reforço para estudar a influência de tratamentos na fibra de Juta nas propriedades mecânicas (ensaios de tração, flexão, impacto superficial, dureza e absorção de água); Khan et al., (2009) realizou um estudo do tratamento da fibra de Juta, porém em um compósito híbrido, para as propriedades mecânicas tais como resistência à tração e flexão, módulo de tração e flexão, resistência ao impacto Charpy e temperatura de distorção de calor. Porém, a mesma também é utilizada in natura (Tinô et al., 2014).

Além disso, muitas estruturas necessitam de mudanças ao longo de suas seções: eixos de rotação devem ter ressaltos projetados sobre eles para que os rolamentos possam ser encaixados corretamente e assim suportar as cargas axiais; devem também ter rasgos de chaveta usinados para encaixar polias e engrenagens. Outros elementos necessitam de furos, ranhuras e entalhes de vários tipos.

Assim sendo, como nos materiais convencionais, nos materiais compósitos, a alteração brusca da seção de área de um elemento estrutural leva a um fenômeno denominado de concentração de tensão (Awerbuch e Madhukar, 1985, Shigley e Mischke, 2002; Aquino e Tinô, 2014).

Nesse sentido, a proposta desse trabalho é um estudo investigativo envolvendo a resposta mecânica (Resistência Última à Tração, Módulo de Elasticidade Longitudinal e Deformação de Ruptura), os modos (características) da fratura, a Resistência Residual e aplicações dos modelos de critérios de falha (PSC e ASC) em um Laminado Híbrido de matriz polimérica com presença de descontinuidades geométricas, furos centrais de diferentes diâmetros $(6 \mathrm{~mm}, 7,5 \mathrm{~mm}$ e $9 \mathrm{~mm})$, em sua seção longitudinal, com largura constante, ou seja, variando a relação $w / D$, sob a ação do ensaio de tração uniaxial.

\section{I MATERIAIS E MÉTODOS}

\section{Laminado e corpos de prova:}

Na elaboração do material proposto para estudo foram utilizados como matriz 
a resina de poliéster insaturada orto-tereftálica NOVAPOL L120, como agente do sistema catalítico (cura a temperatura ambiente) foi usado o MEKP (metil-etilcetona) catalisador utilizado em vasta escala na indústria de plásticos reforçados, e como reforço foram utilizados quatro camadas do tecido têxtil bidirecional de fibras de Juta "in natura" (gramatura: $306 \mathrm{~g} / \mathrm{m}^{2}$, obtido no comércio local e utilizado comumente em artesanato e sacarias) e uma camada do tecido têxtil bidirecional de fibras de vidro-E (gramatura: $600 \mathrm{~g} / \mathrm{m}^{2}$, fornecido pela Tecniplas Indústria e Comércio Ltda), a Fig. 1 mostra uma esquematização do laminado híbrido proposto, que teve sua fabricação pelo processo hand lay-up e apresentou uma espessura de $6,0 \mathrm{~mm}$. A densidade volumétrica do laminado, obtida pela norma ASTM D792 (2008), $1.26 \pm 0.88 \mathrm{~g} / \mathrm{cm}^{3}$, comprovando que o mesmo pode ter sua aplicação em estruturas leves.

Para confeccionar os corpos de provas (CP's) para realização do estudo a influência da variação do diâmetro de um furo central (relação $w / D$ ), nas propriedades mecânicas à tração do laminado híbrido foram utilizados as normas ASTM D3039 (2008) e ASTM D5766 (2011), os corpos de provas (CP's) estudados são: WH - CP's híbridos sem furo; H6 - CP's com furo de 6.0 mm e diâmetro; H7.5 - CP's com furo de 7.5 mm e diâmetro; e H9 - CP's com furo de 9,0 mm e diâmetro. Todos os CP's propostos apresentam o comprimento de $250 \mathrm{~mm}$ e espessura de aproximadamente $6 \mathrm{~mm}$, porém a largura do WH é de $25 \mathrm{~mm}$, enquanto que as das demais amostras são de 36mm, seguindo as normas. Logo, apresentando as relações $w / D$ de 6,0, 4,8 e 4,0, para os CP's H6, H7.5 e H9, respectivamente. 


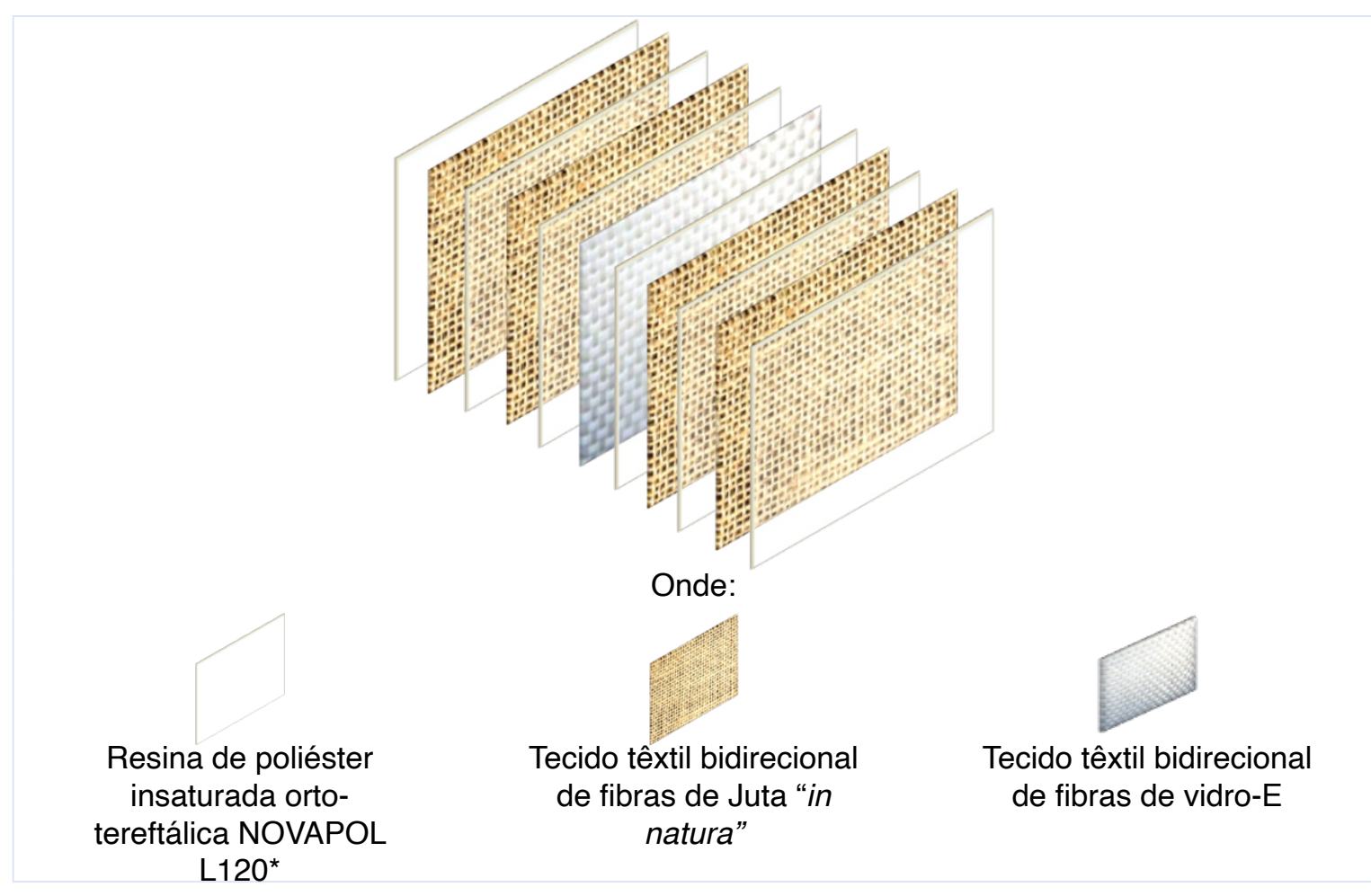

Figura 1. Configuração do Laminado Híbrido (LH).

* As camadas transparentes de resina são apenas para ilustração já que as mesmas são impregnadas diretamente nas camadas de reforço do laminado.

Para obter as dimensões, após o corte dos corpos de prova, foram realizados os procedimentos de lixamento e polimento nas faces cortadas pelo disco de corte. Para tanto, foram utilizadas lixas d'água de números 150, 220, 320, 400, 600 e 1200 , e o polimento foi feito em uma politriz motorizada, utilizando como abrasivo a alumina de $0,01 \mu \mathrm{m}$. Para realização dos furos foram utilizadas brocas helicoidais de aço rápido com os diâmetros de $6 \mathrm{~mm}, 7,5 \mathrm{~mm}$ e $9 \mathrm{~mm}$. Destaca-se que como a largura dos CP's é constante, ao variar o furo, estamos variando a relação $w / D$.

\section{Ensaio de tração uniaxial:}

Para a determinação das propriedades mecânicas de resistência última, módulo de elasticidade longitudinal (determinado na direção de aplicação da carga) e deformação na ruptura, para os corpos de prova com e sem presença de descontinuidade geométrica, foram realizados os ensaios de tração uniaxial utilizando as normas ASTM D3039 (2008) e ASTM D5766 (2011).

Os ensaios foram realizados utilizando uma máquina de Ensaios Universal Mecânica (Shimadzu Autograph AGI-250 KN) com capacidade máxima de $250 \mathrm{kN}$, a uma velocidade de deslocamento de $1,0 \mathrm{~mm} / \mathrm{min}$,e foram realizados à temperatura ambiente $\left(25{ }^{\circ} \mathrm{C} \pm 2^{\circ}\right)$. Os testes foram conduzidos a uma velocidade de deslocamento de $1,0 \mathrm{~mm} / \mathrm{min}$ à temperatura ambiente. 


\section{Análise da Fratura:}

A caracterização da fratura macroscópica foi realizada e fundamentada de acordo com as normas ASTM D3039 (2008) e ASTM D5766 (2011), na qual descreve e caracteriza todos os tipos de fraturas válidas. As imagens são obtidas por meio do sistema de scanner digital.

\section{Propriedades Residuais: Critérios de Falha PSC e ASC:}

A influência das perdas na resistência à tração e no módulo de Young nos laminados compósitos, devido à presença da descontinuidade geométrica, foi estudada através dos cálculos da Resistência Residual (RS) (Santos, 2012 e Tinô et al., 2014) dos laminados compósitos, segundo a Eq. (1):

$$
R S=\frac{\sigma_{\text {Notched }}}{\sigma_{\text {Unnotched }}}
$$

Onde: $\sigma_{\text {Notched }}$ é definida como a resistência última à tração dos corpos de prova com furo (calculada na área de maior seção transversal, segundo a norma ASTM D5766, 2011); $\sigma_{\text {Unnotched }}$ corresponde à resistência última à tração dos corpos de prova sem o furo; $E_{\text {Notched }}$ e $E_{\text {Unnotched }}$ correspondem aos módulos de Young longitudinais (medidos na direção de aplicação da carga) dos corpos de prova com e sem furo, respectivamente.

Ao longo dos anos, alguns critérios vêm tentando predizer a Resistência residual de compósitos com presença de furos circulares ou outra descontinuidade geométrica, dentre alguns critérios, destacam-se o Critério da Tensão Pontual (PointStress Criterion - PSC) e o Critério da Tensão Média (Average-Stress Criterion ASC). Nesse estudo, o desafio se caracteriza na viabilidade do uso dessas teorias de falha nos laminados compósitos a base de tecidos híbridos.

O critério PSC assume que a falha deve ocorrer quando a tensão $\left(\sigma_{N}\right)$ a uma certa distância pequena e próxima à vizinhança do furo $d_{0}$ iguala ou ultrapassa o valor da resistência à tração do material $\sigma_{f}$ (ou a resistência à tração da placa sem o furo, $\left.\sigma_{U N}\right)$. De acordo com Nuismer e Whitney (1975), a resistência residual pode ser expressa por:

$$
R S_{P S C}=\frac{\sigma_{N}}{\sigma_{U N}}=\frac{2}{2+\xi_{I}^{2}+3 \xi_{I}^{4}-(K-3)\left(5 \xi_{I}^{6}-7 \xi_{I}^{8}\right)}
$$


Onde:

$$
\xi_{1}=R /\left(R+d_{0}\right)
$$

$R$ é definido como raio do furo e $K$ o fator de concentração de tensão.

O critério ASC assume que a falha deve ocorrer quando a média da tensão $\left(\sigma_{N}\right)$ ao longo de uma pequena distância fixa $a_{0}$ à frente do limite do furo atinge primeiro a resistência à tração do material $\sigma_{f}$ (ou a resistência à tração da placa sem o furo, $\sigma_{U N}$ ). De acordo com Nuismer e Whitney (1975), a resistência residual pode ser expressa por:

$$
R S_{A S C}=\frac{\sigma_{N}}{\sigma_{U N}}=\frac{2\left(1-\xi_{2}\right)}{2-\xi_{2}{ }^{2}-\xi_{2}{ }^{4}+(K-3)\left(\xi_{2}{ }^{6}-\xi_{2}{ }^{8}\right)}
$$

Onde:

$$
\xi_{2}=R /\left(R+a_{0}\right)
$$

Aqui, $R$ e $K$ possuem as mesmas definições citadas no critério PSC.

Para um melhor entendimento das distâncias características $d_{0}$ e $a_{0}$, um percentual de referência destas distâncias em relação à largura líquida da placa $\eta$ (região onde ocorre a concentração de tensão) foi determinada. A largura líquida da placa $\eta$ é definida pela Eq. (6) (Aquino e Tinô, 2012; Tinô et al., 2014), onde $W$ é a largura da maior seção da área dos CP's (36 mm) e $R$ o raio do furo:

$$
\eta=\frac{W}{2}-R
$$

\section{I RESULTADOS E DISCUSSÃO}

\section{Propriedades Mecânicas - Tração Uniaxial:}

A caracterização mecânica do laminado híbrido, para as condições sem furo (WH) e com furo central de $6 \mathrm{~mm}, 7,5 \mathrm{~mm}$ e $9 \mathrm{~mm}$ (H6, H7,5 e H9, respectivamente), está representada na Fig. 2, pelo diagrama tensão $x$ deformação, onde são expostas as cinco curvas válidas obtidas no ensaio de tração uniaxial e requeridas pela norma ASTM D3039 (2008), para cada condição proposta. Destaca-se que foi observado durante o ensaio que 
todos os CP's apresentaram um comportamento "frágil" até a fratura.

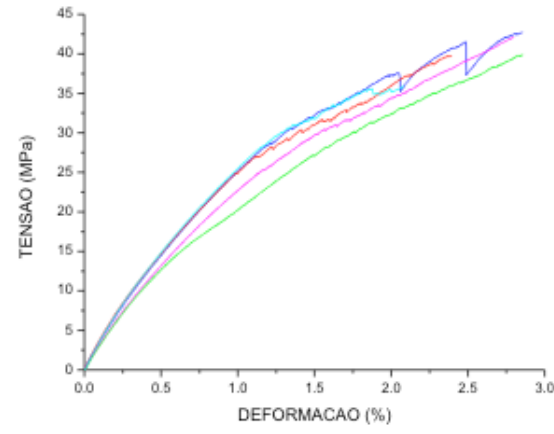

(a)

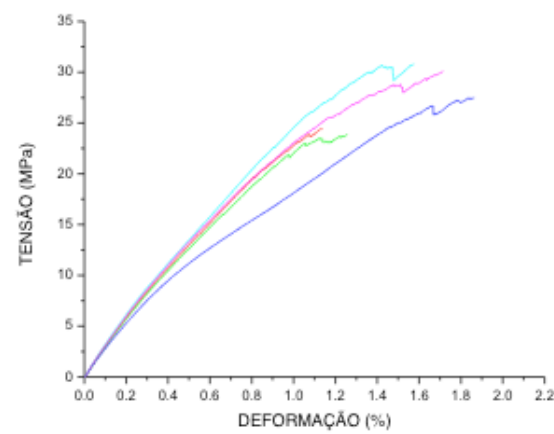

(c)

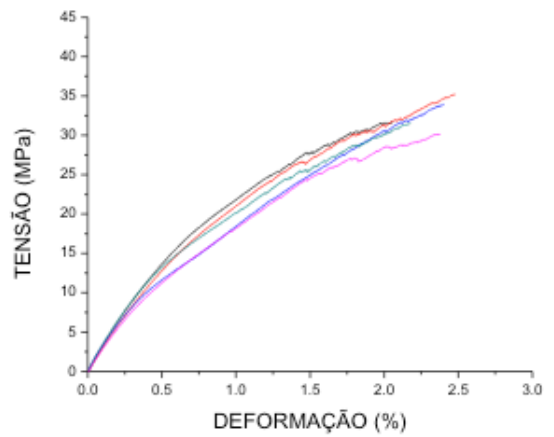

(b)

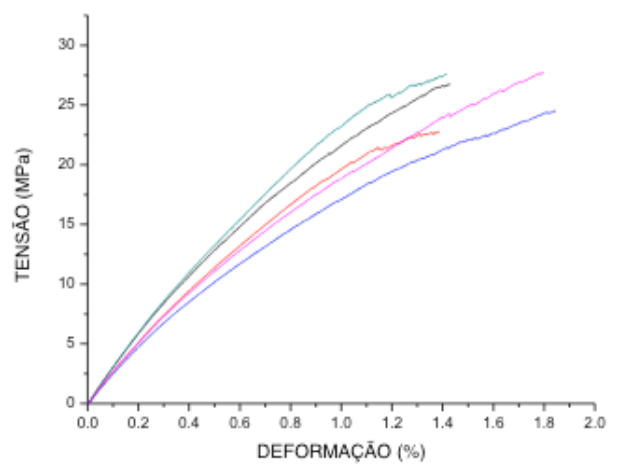

(d)

Figura 2: Diagrama tensão x deformação - Ensaio de tração uniaxial: (a) WH, (b) H6, (c)CH7,5 e (d) $\mathrm{H} 9$.

OWH, Fig. 2 (a), apresentou um comportamento que pode ser considerado linear entre a tensão e a deformação para uma faixa que se estende até aproximadamente $50 \%$ da tensão de ruptura. Essa característica é comum aos laminados compósitos à base de resina poliéster (termofixas) (Aquino et al., 2007). Para os CP's com o furo central, Fig. 2 (b), (c) e (d), esse valor percentual é de aproximadamente de $30 \%$ da carga máxima. Fazendo uma análise do comportamento mecânico, percebe-se que para todas as condições, devido o início o processo de dano, gráfico alterou um pouco o comportamento, tendo o seu módulo diminuído.

A Tab. 1 mostra os valores médios obtidos para a Resistência Última à Tração, para o Módulo de Elasticidade Longitudinal e para a Deformação de Ruptura, bem como seus respectivos desvios padrão para todos os CP's em análise. 


\begin{tabular}{|c|c|c|c|c|c|c|c|c|}
\hline \multirow{2}{*}{ PROPRIEDADES MECÂNICAS } & \multicolumn{2}{|c|}{ WH } & \multicolumn{2}{|c|}{ H6 } & \multicolumn{2}{|c|}{ H7.5 } & \multicolumn{2}{|c|}{ H9 } \\
\hline & Média & DP & Média & DP & Média & $\mathbf{D P}$ & Média & DP \\
\hline $\begin{array}{l}\text { Resistência Última à Tração } \\
(\mathrm{MPa})\end{array}$ & 40,1 & $\pm 2,7$ & 32,5 & $\pm 2,0$ & 27,3 & $\pm 3,2$ & 25,9 & $\pm 2,1$ \\
\hline Módulo de Young (GPa) & 2,9 & $\pm 0,2$ & 2,7 & $\pm 0,3$ & 2,8 & $\pm 0,2$ & 2,5 & $\pm 0,3$ \\
\hline Deformação (\%) & 2,6 & $\pm 0,3$ & 2,3 & $\pm 0,2$ & 1,5 & $\pm 0,3$ & 1,6 & $\pm 0,2$ \\
\hline
\end{tabular}

Tabela1: Propriedades mecânicas - WH, H6, H7.5 e H9 - Tração uniaxial.

* DP significa desvio padrão.

\section{Comparação da Influência do Furo:}

Buscando realizar uma avaliação da influência da variação do tamanho do furo (consequentemente também da variação $w / D$ ) para todos os corpos de prova, resultados estes relacionados com a resposta do laminado compósito frente ao carregamento de tração uniaxial (Fig. 3), percebe-se que, apesar de apresentarem diferentes valores de resistência última e deformação na fratura, o comportamento deles, em termos de módulo de elasticidade (determinado antes do início do dano), independentemente da presença e da dimensão do furo, praticamente não sofreu alteração. Já que, realizando uma análise dos valores de módulo de elasticidade longitudinal encontrados para todos os CP's encontram-se na mesma faixa de desvio padrão, podendo-se descartar as diferenças entre eles (observe a Tab. 1).

Ressalta-se ainda que as grandes perdas registradas nas resistências (principalmente para os furos de maior diâmetro) foram proporcionais as menores taxas de deformações na ruptura, fato este que, também, contribuiu para a manutenção da rigidez do laminado. A Fig. 4 mostra a influência de perda da resistência mecânica de acordo com a variação do tamanho do furo e a relação $w / D$.

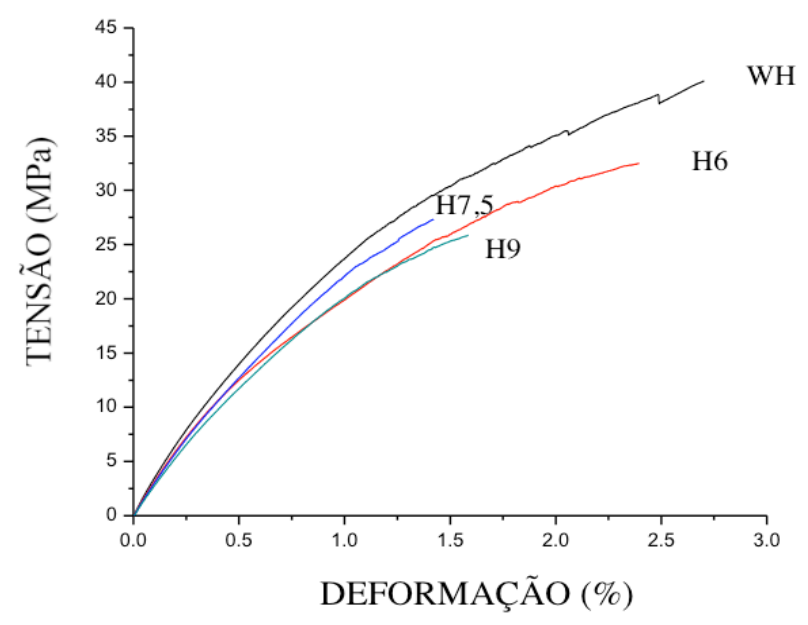

Figura 3: Gráfico tensão x deformação (curvas médias): WH, H6, H7,5 e H9. 


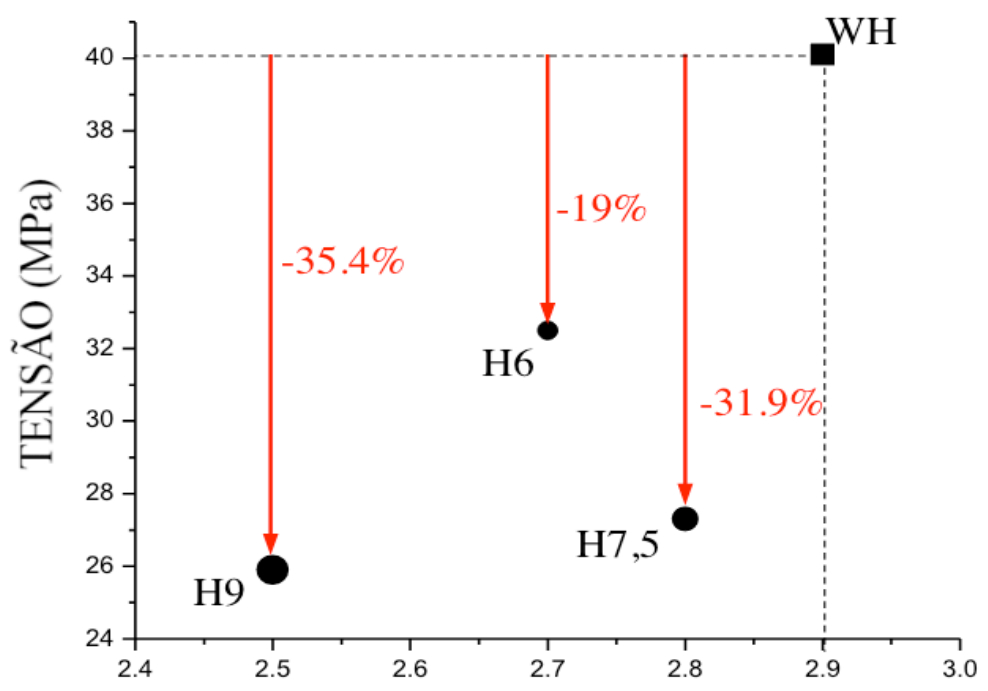

Figura 4: Comparativo da resistência Mecânica.

Para a resistência última à tração, ao se comparar o resultado obtido para os CP's H6 (Razão $w / D=6$, razão normativa), percebe-se que a presença do furo, nesse caso, resultou em uma perda (-) de , aproximadamente, 19\%. Esse valor é semelhante ao encontrado por Tinô et al., 2014 ao analisar a influência de um furo idêntico em um laminado compósito de resina poliéster reforçado por tecidos bidirecionais de fibras de vidro-E. Nesse estudo, a perda na resistência apresentada por um furo central de 6,0 mm de diâmetro foi de $18 \%$, aproximadamente.

Fazendo uma avaliação geral, comparando o resultado obtido para o $\mathrm{H} 9$ com os demais resultados obtidos, percebe-se, em termos de resistência última à tração, que os CP's H9 apresentaram perdas de $35.4 \%, 20.3 \%$ e $5.1 \%$, com relação aos $\mathrm{CP}^{\prime}$ 's $\mathrm{WH}, \mathrm{H} 6$ e H7.5. A diferença entre $\mathrm{H} 9$ e $\mathrm{H} 7.5$ é somente de $5,1 \%$ e apresentou-se dentro da faixa de dispersão dos ensaios, podendo ser negligenciada. Pode-se concluir que à medida que o diâmetro do furo aumenta a resistência do material diminui, porém de forma menos intensa, mostrando que à medida que o furo aumenta, para o material proposto, existiu um alívio no efeito de concentração de tensão.

\section{Análise da Fratura:}

Procedendo à avaliação da análise macroscópica da fratura para os WH (Fig. 5), percebe-se a ocorrência de uma fratura, segundo a Norma ASTM D3039 (2008) do tipo LGM. Observa-se, também, a ocorrência de microfissuração transversal da matriz, bem como o rasgamento do tecido de fibras de vidro, dano característico em materiais compósitos poliméricos reforçados por tecidos de fibras sintéticas (Freire JR. e Aquino, 2002). Esse fenômeno é proveniente da desaderência fibra/matriz provocada pela propagação da microfissuração na interface. É importante lembrar 
que esse rasgamento torna-se perceptível após a retirada dos corpos de prova das garras da máquina.

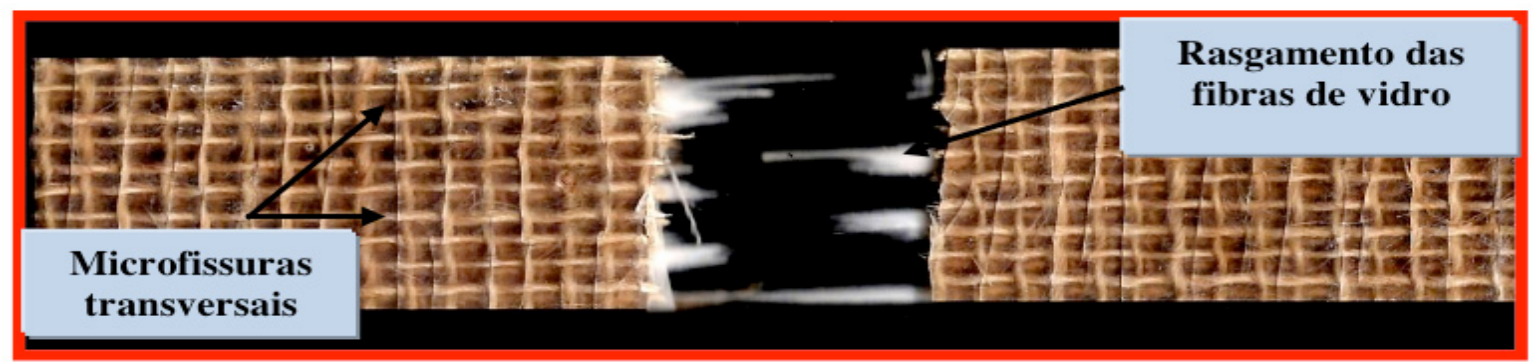

Figura 5: Característica de fratura final para os Corpos de prova WH - Detalhe da região de fratura final.

A Fig. 6, mostra a fratura macroscópica para os CP's com descontinuidade geométrica, para os $\mathrm{H} 6, \mathrm{CH} 7.5$ e $\mathrm{H} 9$ o modo de fratura normalizada do tipo LGM e a ruptura total das fibras de juta e o fenômeno do rasgamento na camada de fibras de vidro.

Os CP's apresentaram pouca fissuração na matriz e com uma fratura final extremamente localizada, a presença do furo desviou algumas microfissuras para sua direção, distorcendo-as da forma apresentada em regiões distantes do furo, onde as fissuras apresentam-se em linha reta, perpendiculares à carga aplicada.
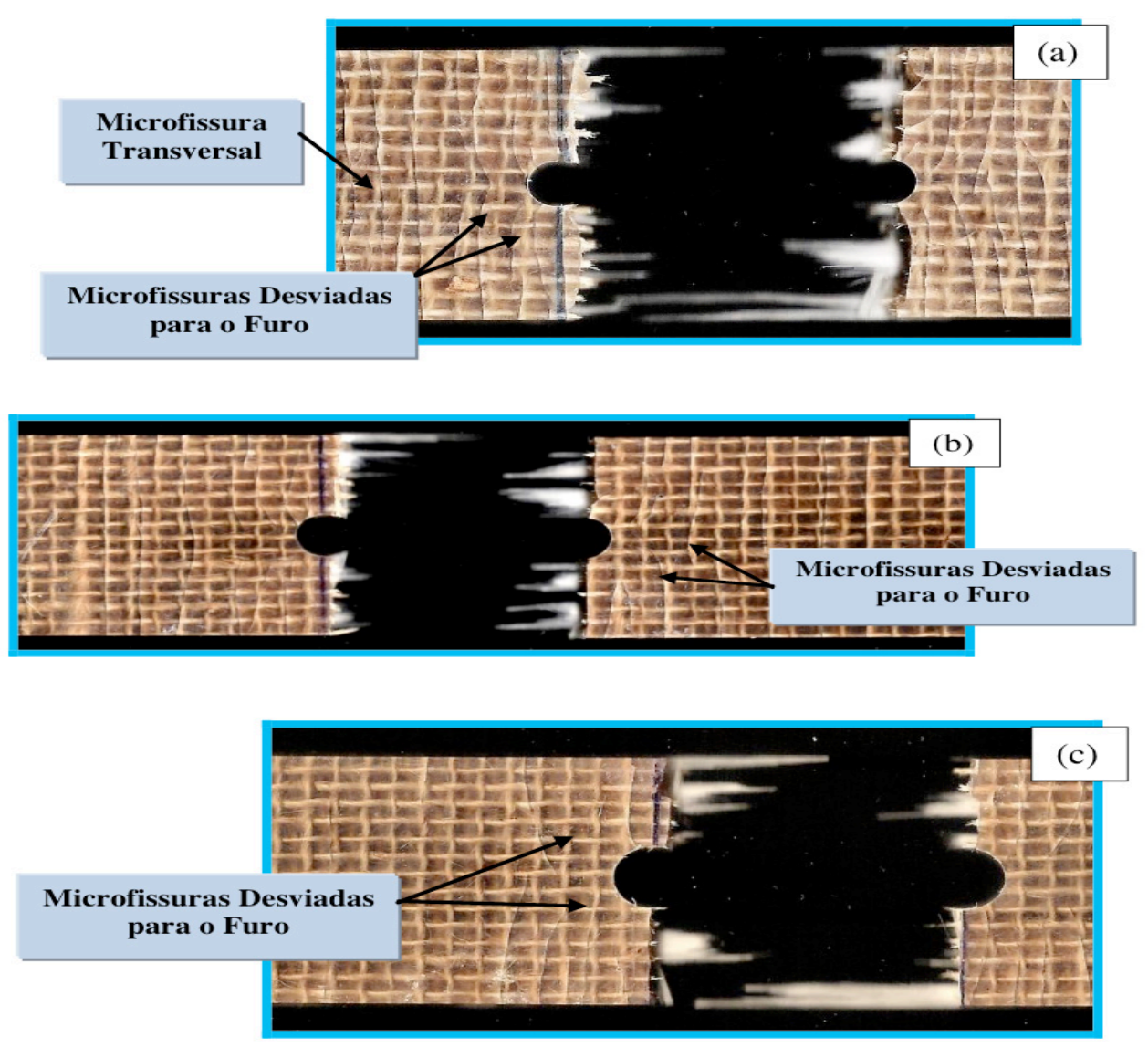

Figura 6: Característica de fratura final para os Corpos de prova: (a) H6, (b) H7,5 e (c) H9. 


\section{Propriedades Residuais - Teorias de Falha PSC e ASC:}

Para a realização do estudo da influência da variação $w / D$ no que diz respeito as distâncias características $a_{0}$ e $d_{0}$ é inicialmente calculado as Resistências residuais (RS) utilizando a equação (1) e o fator de concentração de tensão geométrico $(K)$ (Shigley, 2012) e em seguida calculado as distâncias $a_{0}$ e $d_{0}$ utilizando as teorias ASC (Eq. (2)) e PSC (Eq. (3)). Para melhor entendimento dessas distâncias é colocado o $\eta(\%)$ que mostra o quanto do espaço está distância ocupa da região da concentração de tensão.

\begin{tabular}{|c|c|c|c|c|c|c|}
\hline \multirow{2}{*}{ Configuracão } & \multirow{2}{*}{$\begin{array}{c}\text { Fator de } \\
\text { Concentração de } \\
\text { Tensão } \\
\text { K }\end{array}$} & \multirow{2}{*}{ RS } & \multicolumn{2}{|c|}{ PSC } & \multicolumn{2}{|c|}{ ASC } \\
\hline & & & $\begin{array}{c}\mathrm{d}_{0} \\
(\mathrm{~mm})\end{array}$ & $\begin{array}{c}n \\
(\%)\end{array}$ & $\underset{(\mathrm{mm})}{a_{0}}$ & $\begin{array}{c}n \\
(\%)\end{array}$ \\
\hline H6/WH* & 2,58 & 0,81 & 2,90 & 19,33 & 11,5 & 76,67 \\
\hline H7,5/WH & 2,50 & 0,68 & 2,25 & 15,79 & 4,40 & 30,87 \\
\hline H9/WH & 2,43 & 0,65 & 2,38 & 17,62 & 5,25 & 39,18 \\
\hline
\end{tabular}

Tabela 2: Valores de $d_{0}$ e $a_{0}$.

* Valores retirados da referência 8 em Tinô et al., 2014 para o furo 6 mm.

Com esse resultado, pode-se afirmar que os CP's $\mathrm{H} 6$ retiveram 81,0\% da resistência mecânica apresentada pelos CP's WH. Do mesmo modo, o resultado obtido encontra-se coerente com o encontrado por Tinô et al., (2014). Nesse caso, para um laminado compósito de matriz poliéster reforçado por tecidos bidirecionais de fibras de vidro-E, com a presença de um furo de 6,0 mm de diâmetro, a Resistência Residual foi de 0,820 .

Os CP's $\mathrm{H} 7,5$ retiveram $68 \%$ da resistência mecânica apresentada pelos $\mathrm{WH}$. Ao se comparar os resultados obtidos pelos CP's $\mathrm{H} 7,5$ e H6, percebe-se que, com o aumento do diâmetro do furo, uma redução, em termos de Resistência Residual, de $15,9 \%$.

Já os H9 retiveram $65 \%$ da resistência mecânica apresentada pelos CP's WH. Em comparação aos resultados obtidos por H6, observa-se uma redução na Resistência Residual por parte dos H9 de 20,2 \%. Ao se analisar a RS dos H9 em comparação com $H 7,5$, nota-se que a redução apresentada $(5,1 \%)$ encontra-se na margem de dispersão experimental.

No que diz respeito ao módulo residual, percebe-se valores entre 86 \% e $96 \%$ de retenção do módulo obtido nos WH. Como já citado em anteriormente a diferença obtidas nos módulos elásticos são inferiores estão dentro dos desvios padrões, logo os 
mesmos podem-se considerar que não houve uma diferença significativa entre eles.

Diferentemente do que ocorreu em Tinô et al., 2014, onde somente os valores das distancias características segundo o critério PSC tiveram boa aproximação quando usado o fator de concentração de tensão geométrico, aqui, o uso do fator de concentração apenas geométrico levou a uma boa aproximação das distâncias características (ver Tab. 2) para ambos os critérios PSC e ASC, relevando a influência direta da razão $w / D$ nos mesmos.

\section{I CONCLUSÕES}

- De modo geral, o comportamento de todas as condições em estudo se apresentou de modo "frágil" até a fratura, ou seja, sem a presença do fenômeno do escoamento o qual é característico dos materiais de comportamento dúctil;

- Os desvios padrões apresentadas nos ensaios encontram-se numa faixa dentro da aceitável para os materiais compósitos, em especial, para os compósitos híbridos reforçados por fibras naturais e sintéticas;

- A presença do furo central, de qualquer dimensão, alterou negativamente a Resistência Última à Tração (19, 31,9 e 35,4 \%, respectivamente para H6, H7,5 e H9);

- Quanto ao Módulo de Elasticidade, por outro lado, a diferença encontrada entre os corpos de prova apresentou-se dentro da faixa do desvio padrão dos ensaios;

- Na análise da Resistência Residual, foi comprovada a influência negativa do furo, porém, a diferença entre os corpos de prova H7,5 e H9 apresentou-se dentro da margem de dispersão dos ensaios;

- Quanto ao comportamento à fratura dos laminados, todos, de uma forma geral, apresentaram fratura final normatizada do tipo LGM. Além disso, apresentaram a presença do "rasgamento" e pouca fissuração na matriz. Nos corpos de prova com furo central, as microfissuras transversais foram distorcidas para a vizinhança do furo. Esse fenômeno ficou mais evidente conforme a dimensão do furo foi aumentada.

- Com relação à aplicação do fator geométrico $k$ para a determinação das distâncias características $a_{0}$ e $d_{0}$, tanto o critério PSC como o ASC apresentaram boa aproximação, exceto para o $\mathrm{H} 6$ no qual apenas o critério PSC mostrou-se coerente, ratificando assim, a influência direta da razão w/D no comportamento do compósito híbrido em presença de concentração de tensão. 
Agradecimentos ao suporte financeiro (bolsas) proveniente do CNPq.

\section{REFERÊNCIAS}

Aquino, EMF; Sarmento, LPS.; Oliveira, W; Silva, RV. Moisture effect on Degradation of Jute/Glass Hybrid Composites. Journal of Reinforced Plastics and Composites, Thousand Oaks, v. 26, n. 2, p. 219-233, 2007.

Aquino EMF, Tinô SRL. Notched GFRP: anisotropy, residual strength, and fracture characteristics. J Reinf Plast Compos 2012; 31: 29-40.

ASTM D3039. Standard Test Methods for Tensile Properties of Polymer Matrix Composites. 2008.

ASTM D5766. Standard Test Method for Open-Hole Tensile Strength of Polymer Matrix Composite Laminates. 2011.

ASTM D 792. Standard Test Methods for Density and Specific Gravity (Relative Density) of Plastics by Displacement. 2008.

Awerbuch J, Madhukar MS. Notched strength of composite laminates: Predictions and experiments - A review, J Reinfor Plast Compos 1985; 159.

Batista, ACM, Oliveira JFS, Aquino EMF. Structural Degradation and Mechanical Fracture of Hybrid Fabric Reinforced Composites. Polym Eng Sci 2016: 56:657-668.

Jawaid M, Abdul Khalil HPS. Cellulosic/synthetic fibre reinforced polymer hybrid composites: A review. Carbohydrate Polymers 2011: 86:1-18.

Khan MA; Ganster J; Fink H-P. Hybrid composites of jute and man-made cellulose fibers with polypropylene by injection moulding. Compos Part A 2009: 40: 846-851.

Nuismer RJ, Whitney JM. Uniaxial Failure of Composite Laminates Containing Stress Concentration. In: Fracture Mechanics of Composites, ASTM STP 593 - American Society of testing and materials, 1975: 117-142.

Rahman Md. R; Huque Md. M; Islam Md.N, Hasan M. Improvement of physico-mechanical properties of jute fiber reinforced polypropylene composites by post-treatment. Compos Part A 39 2008: 1739-1747.

Rezaur Rahmana MD, Monimul Huque MD, Nazrul Islam MD, Mahbub Hasan. Improvement of physico-mechanical properties of jute fiber reinforced polypropylene composites by post-treatment. Compos Part A 2008: 39: 1739-1747.

Shahzad A. Hemp fiber and its composites - a review. J Compos Mater 2011: 46(8) 973-986.

Sabell Ahmed K, Vijayarangan S, Chhaya Rajput. Mechanical Behavior of Isothalic Polyesterbased Untreated Woven Jute and Glass Fabric Hybrid Composites. J Reinfor Plast Compos 2006:25(15):1549-1569.

Santos CC. Propriedades Mecânicas Residuais após Incêndio de Betões Normais. doctoral thesis, Faculdade de Ciências e Tecnologia-Universidade de Coimbra, Coimbra-Portugal, 235p, 2012. 
Shigley JE, Mischke CR. Mechanical Engineering Design, In: McGraw-Hill Inc, editor. 5th ed, USA, 2002.

Tinô SRL, Fontes RS, Aquino EMF. Theories of failure average stress criterion and point stress criterion in notched fiber-reinforced plastic. J Compos Mater 2014: 48(21) 2669-2676. 


\section{CAPÍTULO 5}

\section{EFEITOS DE PÓS CERÂMICOS ATIVOS NAS PROPRIEDADES DE COMPÓSITOS POLIMÉRICOS À BASE DE PVDF}

Data de aceite: 05/06/2020

Data de submissão: 04/04/2020

\section{Eriton Rodrigo Botero} Universidade Federal da Grande Dourados, Faculdade de Ciências Exatas e Tecnologia, Dourados- MS http://lattes.cnpq.br/8529549983857097 Jaldair de Araújo e Nóbrega Universidade Federal da Grande Dourados, Faculdade de Ciências Exatas e Tecnologia, Dourados- MS http://lattes.cnpq.br/1566935477819559

RESUMO: Este trabalho traz uma síntese dos resultados sobre as influências de matrizes cerâmicas na formação de fases eletricamente ativas em polímeros de compósitos baseados em PVDF. Através da rota de síntese por via química foram produzidos compósitos eletricamente ativos, cuja concentração de fase ferroelétrica é superior a $90 \%$ das fases cristalinas, o que abre caminho para a síntese de novos materiais com propriedades piezolétricas, flexibilidade e rigidez mecânica superiores aos que existem atualmente no mercado.

PALAVRAS-CHAVE: Compósitos, PVDF, Ferroelétricos.

\section{EEFECTS OF CERAMIC POWDERS IN}

\section{THE PROPERTIES OF PVDF POLIMERIC}

\section{FERROELCTRIC COMPISITES}

ABSTRACT: This work shows the results about the influences of ceramic matrices in the formation of electrically active phases in the polymeric phase of PVDF based composites. Using the chemical synthesis route, electrically active composites were produced, whose ferroelectric phase concentration is greater than $90 \%$ of the crystalline phases, which opens the doors for the synthesis of new materials with piezoletric properties, flexibility and mechanical rigidity superior to those that currently exists.

KEYWORDS: Composites, PVDF, Ferroelectrics

\section{I INTRODUÇÃO}

O Fluoreto de Poli(Vinilideno), conhecido como PVDF, pode ser tratado como um polímero com propriedades eletroeletrônicas que é estudado desde a década de 60, por apresentar os maiores valores de coeficientes piezo e piroelétrico nessa classe de materiais, por sua flexibilidade, excelente processabilidade, estabilidade à ação de produtos químicos e resistência mecânica [1]. Uma característica 
peculiar deste material é o polimorfismo de sua estrutura cristalina, decorrente das diferentes conformações que suas cadeias podem assumir, sendo quatro fases cristalinas mais importantes, denominadas de $a, \beta, \gamma$, e $\delta$ [2], o que confere ao PVDF propriedades distintas em função de sua conformação, incluindo as propriedades piezolétricas da fase $\beta$. A fase mais comum é a a, obtida geralmente a partir da cristalização do polímero fundido [3], ou a partir da cristalização em solução [4]. Nesse último caso, em geral, se obtém um polímero semicristalino, no qual o grau de cristalinidade é em torno de $40 \%$ a $60 \%$ contudo, quando cristalizado a partir da rota de síntese por fusão [5], este valor pode chegar a 90\% [6].

Diferentemente da fase $a$, a fase $\beta$ é polar [2], pois a conformação all-trans de suas cadeias resulta em um momento de dipolo perpendicular à cadeia polimérica [7]. Este tipo de conformação dipolar favorece o surgimento das propriedades ferroelétricas, pois a orientação dos dipolos elétricos, em consequência da rotação das cadeias, pode ser realizada com aplicação de campo elétrico [8]. Assim, por possuir propriedades ferroelétricas proeminentes, a fase $\beta$ é a mais desejada para aplicações tecnológicas em sensores e atuadores $[9,10]$.

As fases $\mathrm{Y}$ e $\delta$ são bem menos intensas e só apresentam propriedades significativas quando inexistem as fases a e $\beta$. Apresentam características apolares, portanto, não sendo relevantes para uso em dispositivos eletrônicos [2].

Quando sintetizado na fase adequada, este polímero apresenta os maiores coeficientes piezo e piroelétrico dentre os polímeros ferroelétricos [2]. Contudo, se comparado às outras classes de materiais ferroelétricos, os baixos valores de seus coeficientes restringem, em parte, suas aplicações. Em contrapartida, os materiais ferroelétricos convencionais, tanto na forma monocristalina quanto policristalina, mesmo apresentando altos coeficientes piezo e piroelétricos, têm como limitador para aplicações tecnológicas a flexibilidade mecânica. Assim, o desenvolvimento de materiais compósitos ferroelétricos envolvendo cerâmicas e polímeros tem se tornado uma alternativa para contornar essas limitações. Desta forma, se torna um grande interesse aliar as melhores propriedades dos ferroelétricos convencionais com a dos polímeros ferroelétricos, buscando o desenvolvimento de um material ferroelétrico flexível com altos valores de suas constantes de interesse.

Polímeros, como o PVDF, são ótimos candidatos a hospedeiros de materiais ativos na síntese de compósitos. Sob o ponto de vista elétrico, por exemplo, há relatos de uso de materiais condutores ou não condutores que podem ser empregados para sintetizar diferentes nanocompósitos à base de PVDF [11]. $O$ grafeno na forma de nanotubos de carbono, são típicos materiais condutores usados na síntese de compósitos de PVDF. Já os materiais dielétricos cerâmicos, como o titanato de bário $\left(\mathrm{BaTiO}_{3}\right)$ [12-14], titanato de estrôncio $\left(\mathrm{SrTiO}_{3}\right)$ [15], óxidos de $\left(\mathrm{Pb}_{1}\right.$ $\left.\mathrm{La}_{\mathrm{x}}\right)\left(\mathrm{Zr}_{1-\mathrm{y}} \mathrm{Ti}_{\mathrm{y}}\right)_{1-1 / 4 \mathrm{x}} \mathrm{O}_{3}$, titanato e zirconato de chumbo modificado com lantânio (PLZT) 
[16], são exemplos de materiais não condutores que são usados na síntese dos compósitos [17,18]. Neste capítulo será apresentado os conceitos fundamentais de síntese de compósitos eletrônicos de PVDF com diferentes materiais cerâmicos, mostrando as influências desses materiais na cristalização das diferentes estruturas do PVDF. Uma análise quanto ao tipo de relação entre propriedade/cerâmica para os compósitos será traçada, mostrando as infinitas possibilidades de estudo de compósitos eletrônicos à base de PVDF.

\section{I FLUORETO DE POLI(VINILIDENO)- PVDF}

O Fluoreto de Poli(Vinilideno), ou PVDF, é um polímero sólido a temperatura ambiente, altamente estável à agentes químicos e mecânicos. Além disso é um material polimérico termoplástico, utilizado em embalagens de produtos químicos corrosivos e em diafragmas de válvulas [1,2]. A literatura já projetava que o PVDF seria um dos materiais eletricamente ativos, ao relatar uma extraordinária propriedade piezoelétrica para essa classe de materiais [19,20].

O PVDF é um polímero produzido através do fluorocarbono, que resulta da polimerização de monómeros de fluoreto de vinilideno (VDF). A fórmula química é repleta de unidades repetidas de fluoreto de vinilideno $\left(\mathrm{CH}_{2}=\mathrm{CF}_{2}\right)$ possuindo um elevado peso molecular médio ( $\mathrm{Mw} \approx 10^{6} \mathrm{~g} / \mathrm{mol}$ ) [2]. O PVDF possui temperatura de fusão, estimada por DSC (Calorimetria Exploratória Diferencial), entre $170^{\circ} \mathrm{C}$ e $200^{\circ} \mathrm{C}\left(\mathrm{f}_{\mathrm{T}}\right)$ e temperatura de transição vítrea $\left(\mathrm{T}_{\mathrm{g}}\right)$ em torno de $-35^{\circ} \mathrm{C}$ [21]. Estas temperaturas dependem fortemente das condições de processamento e da fase cristalina, já que se trata de um material poliamorfo.

A microestrutura do PVDF é na forma de esferas (tipo esferulita mostrado na Figura 1), cujas lamelas cristalinas do PVDF são paralelas ao eixo do núcleo das esferulitas. Os cristais lamelares estão embutidos numa região amorfa da matriz do polímero. À medida que as lamelas cristalinas crescem radialmente do centro das esferulitas para fora, estas divergem e se ramificam, dando origem a uma forma radialmente simétrica [20].

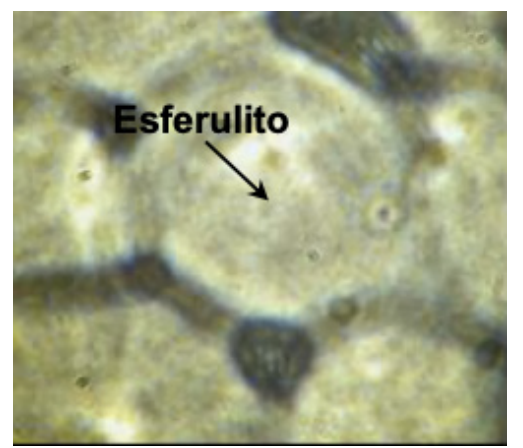

Figura 1: Imagem microestrutural do PVDF evidenciando a formação da estrutura esferulítica. 
O PVDF é um polímero molecularmente linear que apesenta dipolos elétricos permanentes, perpendiculares, bem próximos à direção das cadeias poliméricas. Essa formação de dipolos se dá essencialmente pela diferença de eletronegatividades entre os átomos de flúor e carbono em sua cadeia. Cada forma cristalina é decorrente diretamente das diferentes conformações que a cadeia polimérica pode assumir em função das condições de cristalização. Quando possui uma cadeia em ziguezague planar trans (TTT) compreende a fase $\beta$, quando se tem uma cadeia TGTG' (trans-gauche-trans-gauche) representa as fases a e $\delta$ e

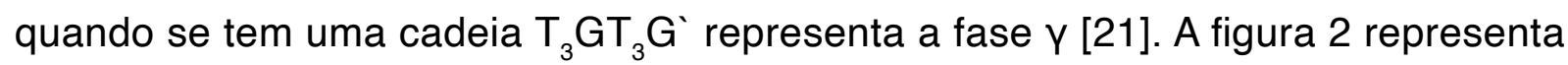
a organização atômica/dipolar do PVDF das fases mais investigadas do PVDF. A cristalinidade do PVDF pode variar entre $40 \%$ a $60 \%$, dependendo do método de preparação, podem chegar ate 90\% [21].

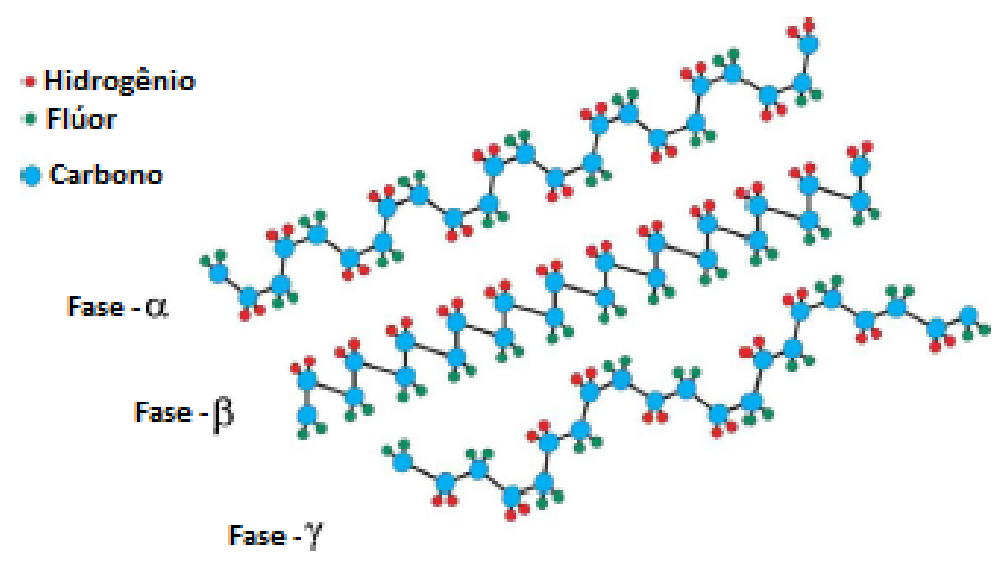

Figura 2: Representação esquemática da conformação da cadeia para as fases a, $\beta$ e $\gamma$ do PVDF. Figura adaptada pela referência [22]

A fase mais comum do PVDF é caracterizada por possuir estrutura apolar, conhecida como fase a, que é obtida a partir da cristalização do material fundido $[20,23]$. A célula unitária da fase a-PVDF é formada por duas macromoléculas e é apolar resultando momentos dipolares dispostos em arranjos antiparalelos [24]. Possui uma estrutura ortorrômbica (grupo P2cm) com dimensões de $\mathbf{a}=4.96 \AA$, $\mathbf{b}$ $=9.64$ Á e c = 4.62 Á, apresentando uma densidade de $1920 \mathrm{Kg} / \mathrm{m}^{3}$ e um valor de entalpia de fusão $(\Delta H f)$ de 93,07 J/g [20].

A fase $\beta$ do PVDF destaca-se entre as outras fases por apresentar momento de dipolo elétrico, com possibilidade de apresentar propriedades piezoelétricas, piroelétricas e ferroelétricas, sendo a mais desejável do ponto de vista tecnológico para aplicação em sensores e atuadores. Esta fase é obtida por estiramento mecânico da fase a a temperaturas inferiores a $100^{\circ} \mathrm{C}$ e com razão de estiramento (relação entre o comprimento final e inicial da mostra) maior ou igual a 4 [2]. A fase também pode ser obtida por solução se a cristalização ocorrer a temperaturas 
inferiores a $70^{\circ} \mathrm{C}$ [25]. A célula unitária na fase é polar, pertencendo ao grupo $\mathrm{Cm} 2 \mathrm{~m}$

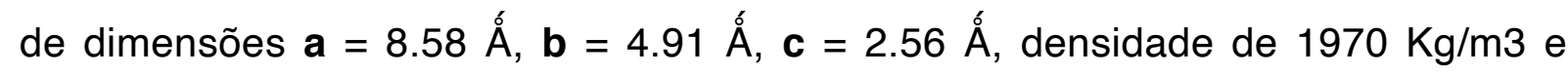
entalpia de fusão $(\Delta H f)$ de 93,07 J/g [23].

Existem dois tipos de fase $\mathrm{Y}$, uma delas cristalizada diretamente do material fundido a temperaturas superiores a $160{ }^{\circ} \mathrm{C}$, formando esferulitas não aneladas, cuja taxa de formação aumenta com o aumento da temperatura de cristalização. $O$ outro tipo de fase $y$ é obtido a partir da transição de fase a em $y$ [26]. A fase $\delta$ é obtida a partir da fase a, através da aplicação de um campo elétrico elevado (>30 $\mathrm{MV} / \mathrm{m})$ [23].

A versatilidade do uso do PVDF em diversas aplicações não se deve somente ao fato de ser um material polimorfo, mas também à interconversão entre essas fases. Ou seja, certos procedimentos experimentais favorecem a conversão de um certo tipo de cristalização para outro. A figura 3 apresenta os procedimentos para a interconversão das fases cristalinas do PVDF para se obter a fase $\beta$ [25].
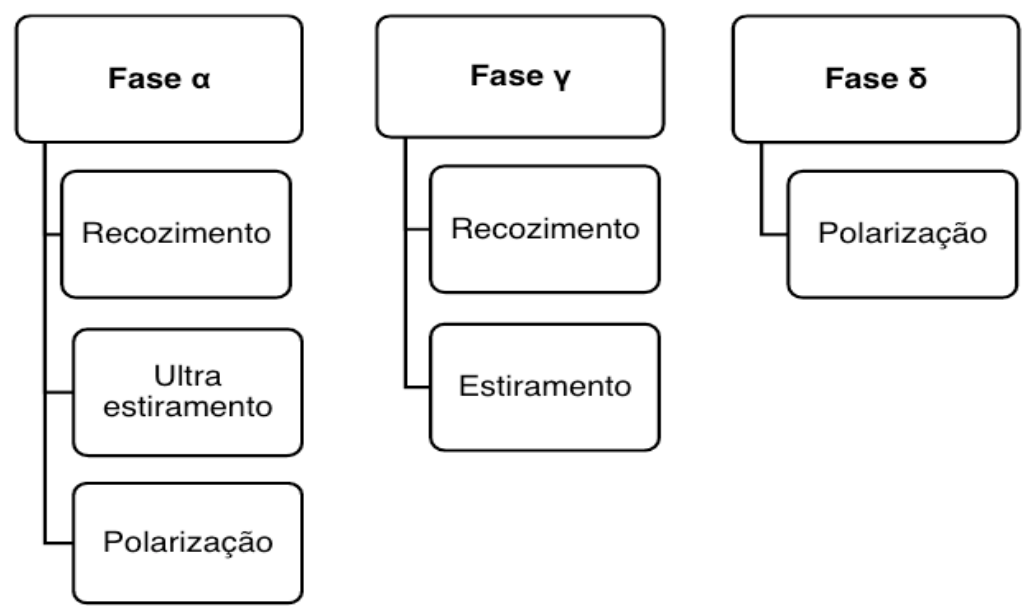

Figura 3: Resumo dos processos de interconversão das diferentes fases cristalinas do PVDF para a fase $\beta$, utilizando pressão, temperatura e campo elétrico.

\section{I CARACTERIZAÇÃO DAS FASES CRISTALINAS DO PVDF POR FTIR}

A identificação das fases cristalinas do PVDF é um problema devido a semelhança da conformação entre suas fases cristalinas e, dependendo das condições de preparação, o mesmo filme pode conter um ou mais fases cristalinas, criando alguns problemas qualitativos e quantitativos na identificação das fases [27]. Uma das técnicas mais utilizadas para identificação dessas fases é a espectroscopia no infravermelho com transformada de Fourier (FTIR), já que as bandas de absorção do PVDF são facilmente detectadas por FTIR. A tabela 1 apresenta as bandas características das fases $a, \beta$ e $y$ do PVDF [28]. 


\begin{tabular}{|c|c|c|}
\hline Banda $\left(\mathrm{cm}^{-1}\right)$ & Fase & Grupo e modo vibracional \\
\hline 408 & $\alpha$ & Balanço $\left(\mathrm{CF}_{2}\right)+$ balanço $\left(\mathrm{CH}_{2}\right)$ \\
\hline 431 & V & Balanço $\left(\mathrm{CF}_{2}\right)$ \\
\hline 444 & $\beta$ & Balanço $\left(\mathrm{CF}_{2}\right)^{3}+$ balanço $\left(\mathrm{CH}_{2}\right)$ \\
\hline 472 & $\beta$ & Vibração ( $\left.\mathrm{CF}_{2}\right)$ (filmes orientados) \\
\hline 488 & Amorfa & \\
\hline 490 & $\beta$ & Vibração $\left(\mathrm{CF}_{2}\right)$ \\
\hline 511 & $\beta$ & Deformação $\mathrm{CF}_{2}$ \\
\hline 512 & $\gamma$ & Deformação $\mathrm{CH}_{2}$ \\
\hline 530 & $\alpha$ & Deformação $\mathrm{CF}_{2}$ \\
\hline 600 & Amorfa & \\
\hline 615 & $\alpha$ & Deformação $\mathrm{CF}_{2}$ \\
\hline 678 & - & $\begin{array}{c}\text { Defeitos na cadeia polimérica devido a ligações } \\
\text { cabeça-cabeça ou cauda-cauda }\end{array}$ \\
\hline 766 & $\alpha$ & Deformação $\mathrm{CF}_{2}$ \\
\hline 778 & $\gamma$ & Balanço $\left(\mathrm{CH}_{2}\right)$ \\
\hline 795 & $\alpha$ & Balanço $\left(\mathrm{CH}_{2}\right)$ \\
\hline 812 & $\beta$ ou $\gamma$ & Deformação $\mathrm{CH}_{2}$ fora do plano \\
\hline 833 & 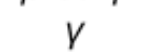 & \\
\hline 840 & $\beta$ ou $y$ & Balanço $\mathrm{CH}_{2}$ \\
\hline 855 & $\alpha$ & Deformação $\mathrm{CH}$ fora do plano \\
\hline 877 & $\beta$ & Balanço $\mathrm{CH}_{2}$ \\
\hline 880 & Amorfa & \\
\hline 976 & $\alpha$ & Deformação $\mathrm{CH}$ fora do plano \\
\hline
\end{tabular}

Tabela 1: Bandas de Absorção do FTIR nas fases $\alpha, \beta$ e y do PVDF, com os respectivos modos vibracionais $[29,30,31]$.

As semelhanças de conformação da cadeia polimérica das fases y e $\beta$, refletem em números próximos das bandas de absorção, como mostra a tabela 1: banda de absorção em $512 \mathrm{~cm}^{-1}$ para a fase $\gamma$, que está próximo da banda em $510 \mathrm{~cm}^{-1}$ para a fase $\beta$. [29]. Da mesma forma ocorre no pico da banda em $840 \mathrm{~cm}^{-1}$, alguns autores consideram somente da fase $\beta[29,30]$ e outros consideram comuns as fases $\gamma e$ $\beta$ [31].

A intensidade dos picos de absorção do espectro de FTIR é diretamente relacionada com a concentração da fase cristalina. Assim, por exemplo, a quantificação do o teor da fase $\beta$ em relação a a em amostras de PVDF pode ser feita através do cálculo da porção entre as fases (considerando que a porção cristalina do polímero se deva apenas a presença das fases $\beta$ e a):

$$
F_{\beta}=\frac{C_{\beta}+C_{\alpha}}{C_{\beta}}
$$

onde $F_{\beta}$ é a fração de fase $\beta$ na porção cristalina, e $C_{\alpha}$ e $C_{\beta}$ são respectivamente as concentrações, em mol $/ \mathrm{cm}^{3}$, da fase $\beta$ e a. Ao escrever a absorbância em termos da concentração molar das fases, temos:

$$
A b s=k \lambda \cdot l \cdot C
$$

onde Abs é a absorbância, $\mathrm{k} \lambda$ é o coeficiente de absorção molar no comprimento de onda $\lambda$, I é a espessura da amostra e $C$ a concentração em mol/cm3. Isolando a 
concentração da equação 2, tem-se:

$$
C=\frac{A b s}{k_{\lambda} \cdot l}
$$

Com os valores do coeficiente de absorção molar dos picos da fase a $(\mathrm{Ka}=$ $6,1 \times 104 \mathrm{~cm} 2 / \mathrm{mol})$ e $\beta(\mathrm{K} \beta=7,7 \times 104 \mathrm{~cm} 2 / \mathrm{mol})$, nos respectivos números de onda de 763 e $840 \mathrm{~cm}-1$, pode-se reescrever a equação 3 substituindo C pela expressão oriunda da Lei de Lambert Berr (equação 2), obtendo:

$$
F_{\beta}=\frac{A b s_{\beta}}{1,26 . A b s_{\alpha}+A b s_{\beta}} \times 100
$$

\section{I COMPÓSITOS POLÍMERO/CERÂMICA}

Compósitos são materiais que possuem pelo menos dois componentes, ou duas fases, com propriedades nitidamente distintas em sua composição. Separadamente os constituintes do compósito mantêm suas características, porém quando suas ações são combinadas eles formam um composto com propriedades impossíveis de se obter com apenas um deles [32]. A criação de modelos para a classificação e organização dos compósitos foi desenvolvida por Newnham e seus colaboradores, os quais foram os primeiros a designarem o termo conectividade, que indica 0 modo como as diferentes fases dos materiais compósitos se interligam [32]. Em compósitos bifásicos, ou sistema de duas fases, essas conectividades possuem dez possibilidades distintas, sendo representada por dois números, o primeiro para o reforço e o segundo para a matriz. Se um material compósito apresentar conectividade numa direção qualquer, diz-se que tem conectividade 1 , se for em duas direções tem conectividade 2 e se for em três direções tem conectividade 3.

Para compósitos com conectividade 0-3, como cerâmica/polímero, a matriz polimérica é auto conectada nas três dimensões, enquanto não há contato algum entre as partículas da cerâmica. Dentre outros padrões de conectividade, os compósitos com conectividade 0-3 apresentam algumas vantagens, como facilidade no preparo e baixo custo [33].

Embora em compósitos não se procure a interação entre as fases constituintes, no caso de compósitos a base de PVDF a mera interação entre as fases na conectividade 0-3 favorece alterações na cristalinidade da matriz polimérica, já que a interconversão entre algumas fases se dá por estiramento, ou seja, uma propriedade mecânica. 


\section{I MATERIAIS}

Para o estudo das influências da rota de síntese, bem como da morfologia das fases cerâmicas usadas na síntese de compósitos ferroelétricos a base de PVDF, foram preparados compósitos ferroelétricos na forma de filmes usando três diferentes matrizes cerâmicas. Para cada matriz cerâmica foram variadas as condições de síntese do material compósito, buscando sempre uma otimização na cristalização e formação da fase $\beta$ do PVDF.

A síntese dos compósitos fez-se inicialmente a dissolução do pó de PVDF (Solef 11010/1001) em dimetilformamida (DMF) Vetec (UV/HPLC) [13], sob agitação mecânica e temperatura ambiente, na proporção de $80 \mathrm{mg}$ de polímero por $\mathrm{mL}$ do solvente. Ao completar a dissolução do polímero foram adicionados, nas devidas proporções em massa, os pós cerâmicos submicrométricos (com tamanho médio na ordem de $70 \mathrm{~nm}$ ) dos três sistemas: um ferroelétrico a base de chumbo (titanato zirconato de chumbo modificado com lantânio); dois ferromagnéticos (ferrita de níquel e ferrita de cobalto); todos com características morfológicas distintas. Após a adição da cerâmica (em distintas proporções), o sistema foi mantido sob agitação por 5 minutos, a temperatura ambiente, para dispersão das partículas de cerâmica na solução polimérica. Após esse período a solução foi transferida para uma placa de Petri, e então foram cristalizadas em estufa, com condições de temperatura e tempo variáveis. Todos os compósitos preparados apresentam espessura em torno de $0,1 \mathrm{~mm}$ e integridade mecânica. Nesse capítulo apresentaremos apenas os resultados mais significativos de cada composição preparada.

\section{I RESULTADOS}

Nos espectros de FTIR dos filmes de PVDF para distintas temperaturas de cristalização, mostrados na Figura 4, verifica-se bandas típicas das fases cristalinas do PVDF, contudo com presença significativa de bandas da fase amorfa (488 e 880 $\mathrm{cm}^{-1}$ ) [11], independente da temperatura de cristalização. A presença expressiva desse pico indica um baixo grau de cristalinidade nos filmes obtidos, para o intervalo de temperatura $\left(50 \mathrm{a} 90^{\circ} \mathrm{C}\right)$. A respeito das absorções referentes às fases cristalinas do PVDF, nota-se que a presença da fase $\beta\left(840\right.$ e $\left.511 \mathrm{~cm}^{-1}\right)$, é mais favorecida à baixas temperaturas de cristalização, enquanto temperaturas superiores a cristalização do polímero é favorecida na fase a (976, 855, 796, 764, 614 e 532 $\mathrm{cm}^{-1}$ ). Pode-se dizer que baixas taxas de evaporação do solvente, favorecem a formação da fase ferroelétrica (fase $\beta$ ) em relação a fase apolar (fase a). 


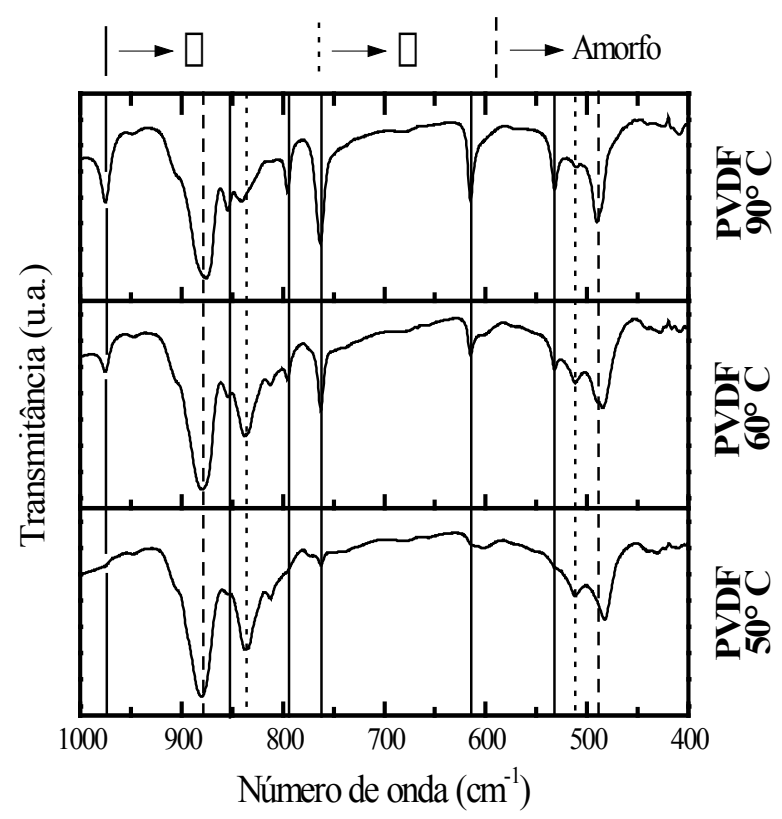

Figura 4: Espectros de infravermelho dos filmes de PVDF cristalizados a (a) 50, (b) 60, e (c) $90^{\circ}$ C.

Na Figura 5 são apresentados os espectros de infravermelho dos compósitos de PVDF/PLZT em forma de filmes, cristalizados a $50^{\circ} \mathrm{C}$. Foram adicionadas nas concentrações de 1,10 e $25 \%$ em massa, cerâmicas de PLZT em matrizes poliméricas de PVDF. A banda alargada na região de $595 \mathrm{~cm}^{-1}$, característica da deformação Ti-O, do PLZT, pode ser observada no espectro de FTIR do PLZT puro e dos compósitos. Para essa temperatura de cristalização, todas as composições apresentaram bandas proeminentes para a fase ferroelétrica (fase $\beta$ ) e amorfa. A fase apolar (fase a) pode ser identificada apenas pela banda de baixa intensidade em $763 \mathrm{~cm}^{-1}$. Comparando os espectros entre as diferentes composições deste sistema, e também com o espectro do PVDF puro cristalizado nesta mesma temperatura (Figura 4), verifica-se que o perfil do espectro referente ao polímero é praticamente o mesmo, o que nos permite dizer que a inserção das partículas cerâmicas de PLZT não alteram de forma significativa as propriedades estruturais da matriz polimérica.

Usando a equação 4 , e as intensidades dos picos de absorção obtido por FTIR de todas as amostras, estimou-se o teor de fase $\beta(F \beta(\%))$ em relação as demais fases cristalinas do PVDF nos compósitos estudados. Os valores $F \beta(\%)$ são apresentados no gráfico da Figura 6 para todas as amostras preparadas nessa série. 


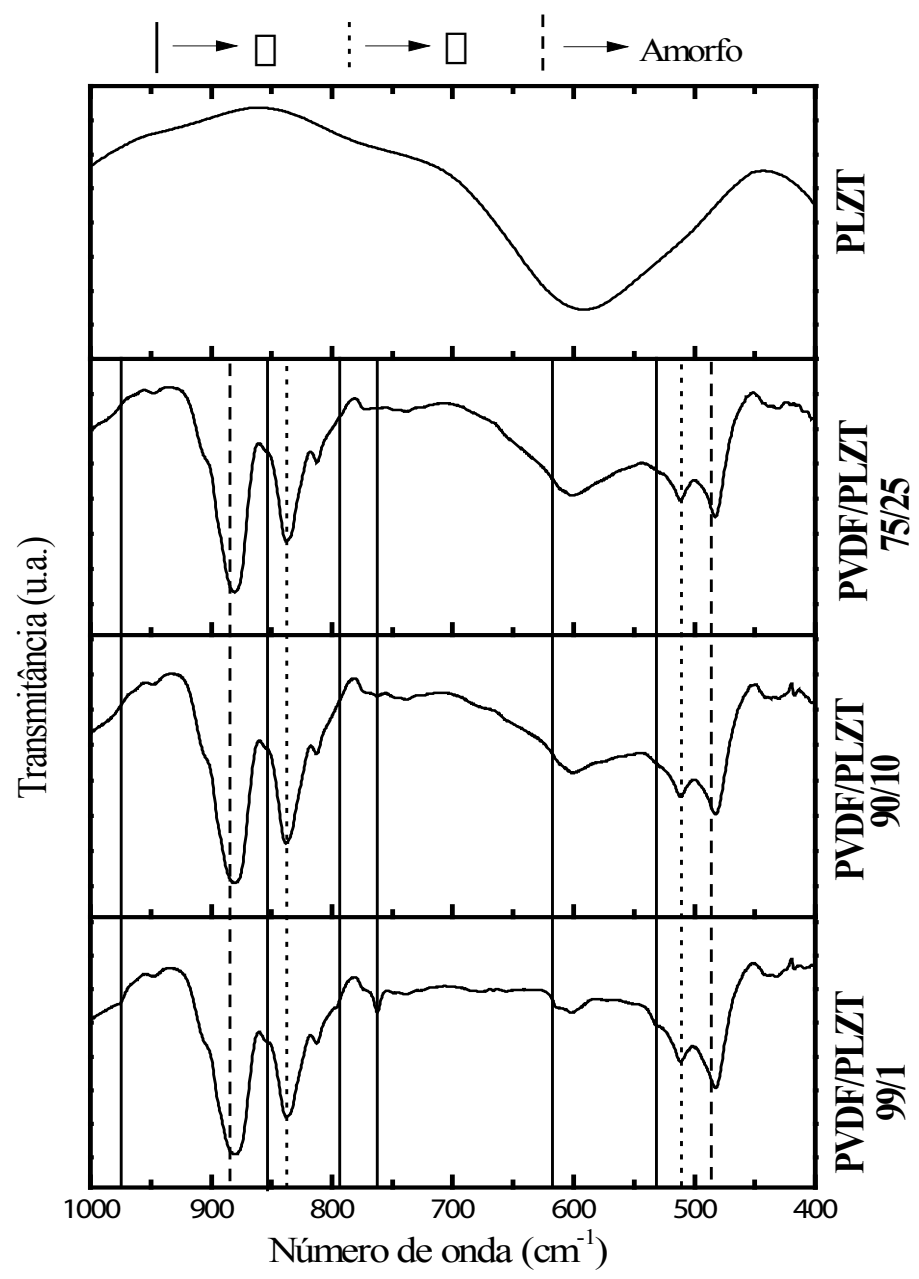

Figura 5: Espectros de infravermelho do PLZT em pó e dos filmes, cristalizados a $50^{\circ} \mathrm{C}$, de compósitos a base de PVDF/PLZT, nas composições de 1 a 25\% em massa de cerâmica.

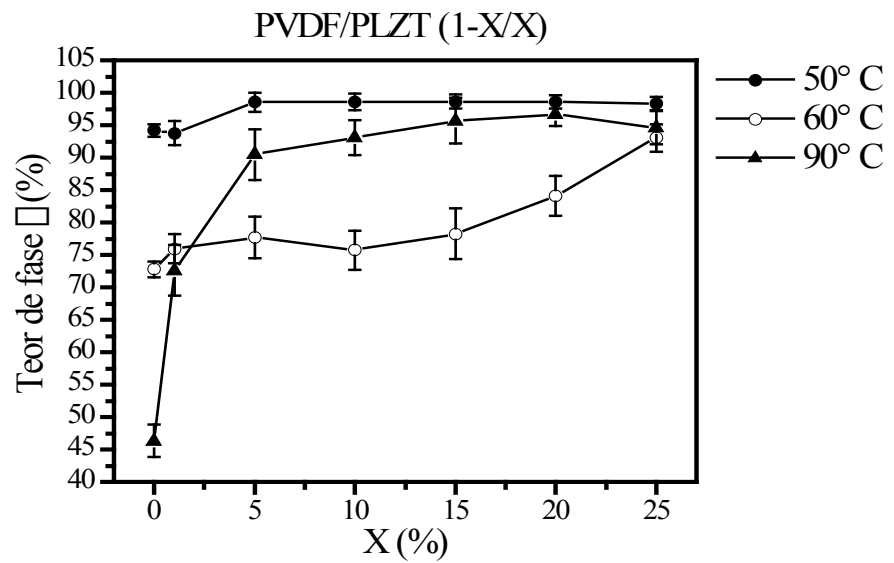

Figura 6: Teor de fase $\beta$ nos filmes de PVDF/PLZT, cristalizados a 50, 60 e $90^{\circ} \mathrm{C}$, de PVDF e compósitos a base de PVDF/PLZT, nas composições de 1 a 25\% em massa de cerâmica.

Nos compósitos, nota-se que além da taxa de evaporação do solvente, a concentração de cerâmica também influenciou nos valores de $F \beta(\%)$. Contudo, o peso deste novo parâmetro é fortemente relacionado com a temperatura de cristalização dos filmes, uma vez que no intervalo de temperatura avaliado, a influência é mínima para baixas temperaturas $\left(50^{\circ} \mathrm{C}\right)$, enquanto para altas temperaturas $\left(90^{\circ} \mathrm{C}\right)$ esta influência foi mais expressiva. A ponto dos compósitos cristalizados à $90^{\circ} \mathrm{C}$ 
apresentarem valores de $\mathrm{F} \beta(\%)$ superiores aos dos compósitos cristalizados à $60^{\circ}$ C, para concentrações de PLZT superiores a 10\% em massa.

Assim por essa experiência, usou-se como parâmetro para a síntese de novos compósitos taxas de concentração de cerâmica superiores a $25 \%$ em massa no compósito e temperaturas de cristalização de $50^{\circ} \mathrm{C}$.

Novos compósitos de PVDF foram sintetizados, envolvendo, agora, matrizes cerâmicas de Ferrita de Cobalto $\left(\mathrm{CoFe}_{2} \mathrm{O}_{4}\right.$, ou somente $\left.\mathrm{CFO}\right)$, seguindo a concentração $70 \%$ em peso de PVDF e $30 \%$ em peso de $\mathrm{CoFe}_{2} \mathrm{O}_{4}$. Os compósitos foram cristalizados à $50^{\circ} \mathrm{C}$ em três diferentes períodos. A Figura 7 mostra teor de fase $\beta(F \beta(\%))$ em relação as demais fases cristalinas do PVDF nos compósitos PVDF/CFO em função do tempo de cristalização em horas.

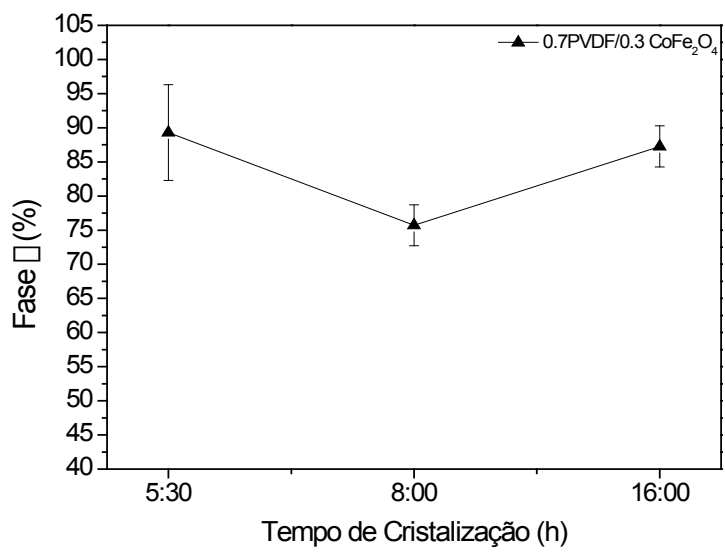

Figura 7: Teor de fase $\beta$ nos filmes, cristalizados a $50^{\circ} \mathrm{C}$, de PVDF/CFO em função do tempo de cristalização.

Tempos de cristalização inferiores a 360 minutos não foram suficientes para a remoção total do solvente (DMF) utilizado no processo, de modo que os filmes ainda apresentavam umidade em tempos inferiores. Tempos superiores a 8 horas de cristalização já eram suficientes para criar mudança de coloração nos filmes, acredita-se que seja pela própria degradação do PVDF, já que tempos superiores há 16 horas os filmes não eram estáveis e não eram autossustentados. Assim, com base nesses resultados verifica-se que tempos de cristalização suficientes para a remoção do solvente utilizado apresentam os melhores resultados na formação da fase $\beta$ em filmes compósitos à base de PVDF.

Por fim, uma última variável referente à influência do tamanho médio de partícula da cerâmica adicionada ao PVDF para a formação dos compósitos foi ponderada. Assim, sintetizou-se compósitos de PVDF com ferrita de níquel $\left(\mathrm{NiFe}_{2} \mathrm{O}_{4}\right.$, ou NFO) nas concentrações de 70\% em peso de PVDF com 30\% em peso de NFO, cristalizados à $50^{\circ} \mathrm{C}$ por 360 minutos. A Figura 8 mostra teor de fase $\beta(F \beta(\%))$ em relação as demais fases cristalinas do PVDF nos compósitos PVDF/NFO em função 
do tamanho médio de partícula da cerâmica.

Para essa variável, nota-se que o tamanho médio de partículas em torno de $80 \mathrm{~nm}$, ou inferiores, propiciam a maior concentração de fase $\beta$ nos compósitos. Tamanhos de partículas superiores causam uma redução significativa na formação da fase de interesse.

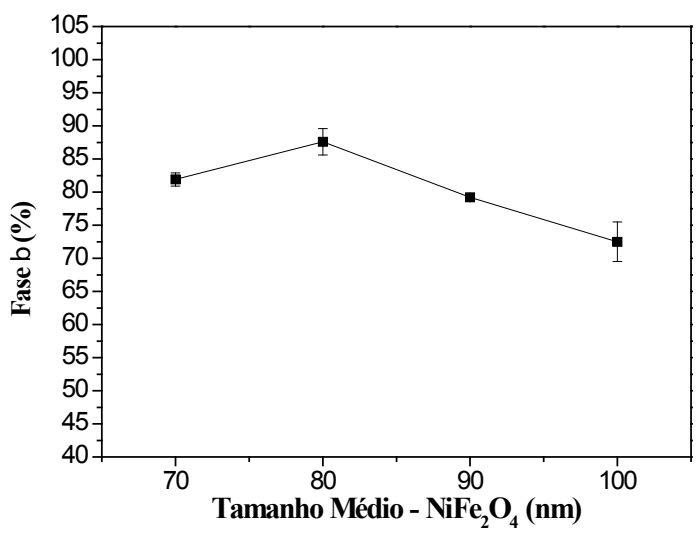

Figura 8: Teor de fase $\beta$ nos filmes, cristalizados a $50^{\circ} \mathrm{C}$ por $360 \mathrm{~m}$, de PVDF/NFO em função do tamanho médio de partícula cerâmica.

\section{I CONCLUSÕES}

É possível a junção de materiais cerâmicos à matrizes poliméricas de PVDF, criando o que se pode chamar de compósito polímero/cerâmica. Almejando uma futura síntese de materiais ferroelétricos funcionais, nesse trabalho usou-se diferentes sistemas cerâmicos eletrônicos, inclusive um ferroelétrico, e estudou-se os efeitos dos dopantes nas propriedades estruturais do PVDF, visando a obtenção de uma fase ferroelétrica ativa desse polímero. Independente da cerâmica utilizada, mas dependente da rota de síntese, observou-se que grandes concentrações de cerâmica, superior a 30\% em peso no compósito, baixas temperaturas e tempo de cristalização e com pós-cerâmicos submicrométricos, inferiores à $200 \mathrm{~nm}$, é possível obter compósitos poliméricos cristalizados com $90 \%$ de fase eletricamente ativa, ou seja, ferroelétrica. Tais condições abrem caminhos para a síntese de materiais ferroelétricos compósitos com otimização de suas propriedades ferroelétricas e possível uso em dispositivos piezoelétricos flexíveis e mecanicamente resistentes.

\section{REFERÊNCIAS}

[1] Nakamura. K e Y. Wada, J. Polym. Sci. A-2 9, 161, 1971.

[2] NALWA, H. S. Ferroelectric Polymers: Chemistry, Physics and Applications. 1. ed. New York: Marcel Dekker, Inc., 1995. 
[3] WASER, R.; BÖTTGER, U.; TIEDKE, S. Polar Oxides Properties, Characterization and imaging. Weinheim: WILEY-VCH Verlag GmbH \& Co. KGaA, 2005.

[4] COSTA, L. M. M.; BRETAS, R. E. S.; GREGORIO, JR., R. Caracterização de Filmes de PVDF- $\beta$ Obtidos por Diferentes Técnicas. Polímeros: Ciência e Tecnologia, v. 19, n. 3, p. 183-189, 2009.

[5] GREGORIO, JR., R.; BORGES, D. S. Effect of crystallization rate on the formation of the polymorphs of solution cast poly(vinylidene fluoride). Polymer, v. 49, n. 18, p. 4009-4016, 2008.

[6] Sharma T, Je S S, Gill B and Zhang J X 2012 Sensors Actuators A 17787.

[7] FURUKAWA, T.; DATE, M.; FUKUDA, E. Hysteresis Phenomena in Polyvinylide Fluoride Under High Electric Field. Journas of Applied Physics, v. 51, n. 2, p. 1135-1142, 1980.

[8] FUKADA, E. History and recent progress in piezoelectric polymers. IEEE Ultrasonics, Ferroelectrics, and Frequency Control Society, v. 47, n. 6, p. 1277-1290, 2000.

[9] XU, Y. Ferroelectric materials and their applications. Amsterdan: NorthHoland, 1991.

[10] HAERTLING, G. H. Electronic Ceramics: Properties, Devices, and Applications. New York: Marcel Dekker, INC, 1988.

[11] Prateek, Vijay Kumar Thakur, Gupta, Raju Kumar. Recent Progress on Ferroeletric Poymer-Based Nanocomposites for High Energy Density Capacitors: Synthesis, Dieletric Properties, and Future Aspects. Chem. Rev. 2016, 116, 7, 4260-431.

[12] Hoshina, T. Size Effect of Barium Titanate Fine Particles and Ceramics. J. Ceram. Soc. Jpn. 2013, 121, 156-161.

[13] Schumacher, B.; Geßwein, H.; Haußelt, J.; Hanemann, T. Temperature Treatment of Nano-Scaled Barium Titanate Filler to Improve the Dielectric Properties of High-k Polymer Based Composites. Microelectron. Eng. 2010, 87, 1978-1983.

[14] Padalia, D.; Bisht, G.; Johri, U. C.; Asokan, K. Fabrication and Characterization of Cerium Doped Barium Titanate/PMMA Nanocomposites. Solid State Sci. 2013, 19, 122-129.

[15] Nisa, V. S.; Rajesh, S.; Murali, K. P.; Priyadarsini, V.; Potty, S. N.; Ratheesh, R. Preparation, Characterization and Dielectric Properties of Temperature Stable SrTiO3/PEEK Composites for Microwave Substrate Applications. Compos. Sci. Technol. 2008, 68, 106-112.

[16] G. R. Salmazzo, E. A. Falcão, A. R. L. Caires, D. Garcia, J. A. Eiras, E. R. Botero, Síntese e caracterização estrutural de compósitos a base de poli(fluoreto de vinilideno)/ $\left(\mathrm{Pb}_{0,91} \mathrm{LaO}_{, 09}\right)$ $\left(\mathrm{Zr}_{0,65} \mathrm{Ti}_{0,35}\right)_{0,98} \mathrm{O}_{3}$, Cerâmica 60 (2014) 83-87.

[17] Piskunov, S.; Heifets, E.; Eglitis, R. I.; Borstel, G. Bulk Properties and Electronic Structure of SrTiO3, BaTiO3, PbTiO3 Perovskites: An abinitio HF/DFT Study. Comput. Mater. Sci. 2004, 29, $165-178$.

[18] Kong, L. B.; Zhang, T. S.; Ma, J.; Boey, F. Progress in Synthesis of Ferroelectric Ceramic Materials via High-Energy Mechanochemical Technique. Prog. Mater. Sci. 2008, 53, 207-322.

[19] J. G. Bergman, J. K. McFee e G. R. Crane, Appl. Phys. Lett. 18, 203 (1971).

[20] HEYMANS, N. \& EL MOHAJIR, B. E. (2001) - "Changes in Structural and Mechanical Behaviour of PVDF with Processing and Thermomechanical Treatments. 1. Change in Structure", Polymer, 42(13):5661-5667. 
[22] Martins, P.; Lopes, A. C.; Lanceros-Mendez, S. Electroactive Phases of Poly(Vinylidene Fluoride): Determination, Processing and Applications. Prog. Polym. Sci. 2014, 39, 683-706.

[23] LOVINGER, A. J. (1982) Developments in crystalline polymers. Applied Science Publishers Ltd., p. 196-273, 1982.

[24] HUANG, C.; ZHANG, Q. M.; XIA, F \& SU, J (2004) "Electroactive Polymer (EAP) Actuators as Artificial Muscles: Reality, Potencial and Challenges" Edited by Yoseph Bar-Cohen (SPIE - The International Society for Optical Engineering).

[25] CESTARI, M. \& GREGÓRIO Jr., R. (1994) - "Effect of Crystallization Temperature on the Crystalline Phase Content and Morphology of Poly(vinylidene fluoride)", Journal of Polymer Science Part B: Polymer Physics, Vol 32 (5):859-870.

[26] CAPITÃO, R. C. \& GREGÓRIO Jr., R. (2000) - "Morphology and Phase Transition of High Melt Temperature Crystallized Poly(vinylidene fluoride)", Journal of Material Science, Vol 35 (2):299-306.

[27] Boccaccio T, Bottino A, Capannelli G, Piaggio P. Characterization of PVDF membranes by vibrational spectroscopy. Journal of Membrane Science 2002;210:315-29.

[28] Kepler RG, Anderson RA. Piezoelectricity and pyroelectricity in polyvinylidene fluoride. Journal of Applied Physics 1978; 49:4490-4.

[29] Gregorio R. Determination of the alpha, beta, and gamma crystalline phases of poly(vinylidene fluoride) films prepared at different conditions. Journal of Applied Polymer Science 2006;100:3272-9.

[30] Lanceros-Méndez S, Mano JF, Costa AM, Schmidt VH. FTIR and DSC studies of mechanically deformed beta-PVDF films. Journal of Macromolecular Science: Physics 2001;B40:517-27.

[31] Gregorio R, Capitao RC. Morphology and phase transition of high melt temperature crystallized poly(vinylidene fluoride). Journal of Materials Science 2000;35:299-306.

[32] NEWNHAM, R. E.; SKINNER, D. P. \& CROSS, L. E. (1978) - "Connectivity and Piezoelectric Pyroelectric Composites", Materials Research Bulletin, Vol 13:525-536.

[33] ESTEVES, A. C. C.; BARROS-TIMMONS, A.; TRINDADE, T. Nanocompósitos de Matriz Polimérica: Estratégias de Síntese de Materiais Híbridos. Química Nova, v. 27, n. 5, p. 798-806, 2004. 


\section{SÍNTESE DE NANOPARTÍCULAS DE PRATA OBTIDAS VIA ROTAS QUIIMICA E ELETROQUÍMICA E SUA OTIMIZAÇÃO}

Data de aceite: 05/06/2020

\section{Arthur da Rocha Albertini} Escola Politécnica da USP - Departamento de Engenharia Metalúrgica e de Materiais Guilherme Frederico Bernardo Lenz e Silva Escola Politécnica da USP - Departamento de Engenharia Metalúrgica e de Materiais Rodrigo Labat Marcos Faculdade de Medicina Universidade 9 de Julho Laboratório de Biofotônica

RESUMO: Os estudos de materiais nanométricos vêm avançando rapidamente. Isso ocorre pois em escala nanométrica $\left(10^{-9} \mathrm{~m}\right)$, os materiais apresentam características físicas e químicas muito distintas daquelas conhecidas em outras escalas maiores. A principal propriedade a ser estudada neste trabalho é a maior reatividade química dos materiais nanométricos devido às maiores superfícies de contato que seu tamanho proporciona. A ação bactericida da prata macroscópica já é bastante conhecida, mas, apesar de ter o uso bastante disseminado pelo mundo, os efeitos da prata coloidal, conhecida no Brasil como NanoPrata, ainda são pouco conhecidos. Entretanto, o uso de prata e seus compostos para fins medicinais vem aumentando recentemente, pois os efeitos bactericida e fungicida dos íons $\mathrm{Ag}+\mathrm{e}$ de partículas nanométricas de prata ainda estão sendo descobertos e entendidos. Atualmente soluções de prata já são utilizadas no tratamento de queimaduras e feridas com o intuito de evitar e tratar infecções bacterianas. Aliando os efeitos já conhecidos da prata à maior reatividade química de compostos nanométricos, este trabalho visa estudar a síntese de uma solução de nanopartículas de prata e seus efeitos bactericida e bacteriostático na epiderme humana e canina.

PALAVRAS-CHAVE: Nanotecnologia, Engenharia de Materiais, Biomateriais, Síntese Nanopartículas de Prata

ABSTRACT: Studies of nanometric materials are advancing rapidly. This is happening because on a nanometric scale $\left(10^{-9} \mathrm{~m}\right)$, the materials have physical and chemical characteristics very different from those known in other larger scales. The main property to be studied in this work is the greater chemical reactivity of the nanometric materials due to the larger contact surfaces that its size provides. The bactericidal action of macroscopic silver is already well known, but, despite its widespread use throughout the world, the effects of colloidal silver, known in Brazil as 
Nano-Silver, are still little known. However, the use of silver and its compounds for medicinal purposes has been increasing recently, as the bactericidal and fungicidal effects of $\mathrm{Ag}+$ ions and nanometric silver particles are still being discovered and understood. Currently silver solutions are already used in the treatment of burns and wounds in order to prevent and treat bacterial infections. Combining the already known effects of silver with greater chemical reactivity of nanometric compounds, this work aims to study the synthesis of a solution of silver nanoparticles and their bactericidal and bacteriostatic effects on human and canine epidermis. Silver nanoparticles were synthesized in two different ways: (1) via the Chemical Route, from the metallic complex $\left[\mathrm{Ag}\left(\mathrm{NH}_{3}\right)_{2}\right]+\left[\mathrm{C}_{2} \mathrm{H}_{3} \mathrm{O}_{2}\right.$ - and (2) via the Electrochemical Route: using a controlled potential difference between silver electrodes immersed in deionized water containing $\mathrm{Na}_{2} \mathrm{CO}_{3}$. Reducing agents in different proportions were added for better stabilization and production of colloidal nanoparticles.

KEYWORDS: Nanoparticles, Silver, Biomaterial

\section{I INTRODUÇÃO}

\subsection{Introdução Histórica}

Historicamente, estima-se que a prata foi o terceiro metal a ser descoberto, pouco depois da descoberta do ouro e do cobre. Seus primeiros registros datam de cerca de 3000 aC. Anos depois, apesar de sem embasamento científico, o efeito bactericida desse metal em escalas macroscópicas foi notado, assim como sua baixa toxicidade a humanos.

Tais características decorrem do, ainda estudado, efeito oligodinâmico, em que mesmo em baixas concentrações, os íons de prata ligam-se a cadeias carbônicas sulfurosas existentes nas membranas plasmáticas das células bacterianas, causando assim 'lise' das membranas e posterior morte celular, entre outros mecanismos que acabam causando a morte celular.

\subsection{Introdução Científica}

O termo nanotecnologia foi empregado pela primeira vez em 1959, durante uma palestra do físico norte-americano Richard Feynman intitulada "There's plenty of room at the bottom". Segundo ele, no novo milênio "surgirá uma nova tecnologia, capaz de lidar com átomos e moléculas, a Nanotecnologia". Muito se discutiu sobre o assunto após esse evento, e em 1986, Gerd Binning e Heinrich Rohrer pesquisadores da IBM ganharam o prêmio Nobel pela criação de um microscópio de tunelamento capaz de visualizar estruturas nanométricas, até a escala atômica. 
Estudos na área vêm ganhando muita importância devido à modernização de aparelhos e de processos de caracterização por microscopia que auxiliam no desenvolvimento tecnológico nessa escala.

Uma vertente bastante explorada atualmente é a utilização de nanopartículas para fins medicinais, devido à, já comentada, alta reatividade química de moléculas nanométricas. A área médica carece por potentes antimicrobianos, uma vez que muitas bactérias e fungos já foram selecionados e hoje são resistentes aos antibióticos mais utilizados no mundo.

Dentro do campo da medicina, a prata é muito conhecida como um agente bactericida e fungicida, tanto na forma iônica como na forma metálica. Os resultados dessa utilização da prata mostram alta performance contra infecções bacterianas e baixíssimos índices de toxicidadeaos seres humanos.

\section{I MOTIVAÇÃO E OBJETIVOS}

\subsection{Doenças Autoimunes E Tratamentos Possíveis Em Animais}

A motivação para o início deste trabalho foi o diagnóstico sequencial de doenças autoimunes em um Akita macho de seis anos de idade. Há algum tempo ele foi diagnosticado com três doenças autoimunes. A primeira é conhecida como S.A., sigla proveniente do latim Sebaceous Adenitis, a segunda, IMT, sigla do inglês para Immune Mediated Thrombocytopenia e a terceira de inflamações nas articulações (artrite reumatóide). Desde então vem sendo tratado para Lupus (lúpus eritematoso sistêmico -LES) com imunossupressão (ciclosporina e corticoide) e tratamento de suporte.

\subsection{As Doenças}

\subsubsection{Adenite Sebácea}

A Adenite Sebácea,ou Sebaceous Adenitis,é uma doença inflamatória e hereditária que destrói ou danifica as glândulas sebáceas dos mamíferos. É uma doença rara que ocorre principalmente em cães das raças Akita, Standard Poodles e Braco Húngaro. Os sinais incluem perda de pêlossecundários, descamação e ressecamento da pele, ocasionando feridas e pústulas que podem ou não coçar.

Porém o diagnóstico definitivo é realizado por meio do exame de fragmentos 'infectados' de pele. Em caso positivo da doença, o exame histopatológico revela a presença de um processo inflamatório dasglândulas sebáceas, com destruição 
total ou parcial dessas. A não funcionalidade dessas glândulas leva a deficiências na hidratação da pele do animal, gerando as já citadas feridas.

Apesar de não haver cura para a doença, o tratamento consiste em reduzir a ação inflamatória da doença por meio da ingestão de vitaminas $A$ e $E$, uso de hidratantes de pele e de medicamentos capazes de modular o sistema imunológico canino, a fimde diminuir o processo inflamatório (Hnilica, 2011).

\subsubsection{Immune-Mediated Thrombocytopenia}

A IMT é uma doença autoimune muito séria, nela, o corpo do doente ataca suas próprias plaquetas como se fossem agentes patogênicos. A palavra Thrombocytopenia significa, em linhas gerais, uma doença que causa o abaixamento da quantidade de plaquetas úteis na corrente sanguínea.

As plaquetas são as principais responsáveis pela coagulação sanguínea, portanto, a falta delas pode ocasionar em sangramentos inesperados, aumento no tempo de cicatrização de feridas, hemorragias interna e externa. Esses sangramentos excessivos podem chegar acausar anemia.

A maioria dos sintomas dessa doença está relacionada a sangramentos no nariz e na boca, fraqueza, aumento na frequência respiratória, gengivas pálidas e fezes escuras e avermelhadas (indicando sangramento no trato gastrointestinal).

\subsection{A Combinação Das Doenças}

Uma vez que o animal possui as três doenças citadas anteriormente, as pequenas feridas causadas em sua pele pela Adenite Sebácea se tornam um grande perigo de infecção devido à deficiência de plaquetas ocasionada pela IMT e o tratamento com imunossupressão. Portanto, é preciso que os tratamentos de ambas doenças se desenvolvam em sinergia. Uma possível ajuda neste tratamento, é o desenvolvimento de um creme hidratante bactericida e fungicida à base de prata coloidal que ajudará na cicatrização das feridas, evitando assim, o desencadeamento de novos problemas.

\subsection{OBJETIVOS}

Este trabalho visa estudar diferentes meios de síntese de uma solução coloidal de prata como o objetivo de fabricar um creme bactericida para uso tópico em cães e humanos, bem como sua caracterização. Nesta primeira parte, o trabalho foi focado na síntese eletroquímica das nanopartículas de prata. Posteriormente a pesquisa será focada em um segundo método e em testes in vitro das soluções em colônias de bactérias. 


\subsection{Um Coloide Em Suspensão}

Soluções de prata iônica e soluções de nano-prata são materiais completamente diferentes entre si e possuem características muito distintas. Uma solução de prata iônica é constituída por átomos do elemento prata que perderam um elétron, por isso, os cátions de prata são facilmente combinados com qualquer ânion proveniente de um sal em solução (espécie química que possui excesso de elétrons quando em solução). Caso não haja nenhum sal na água, os íons de prata se dissolvem totalmente na água e não podem ser observados visualmente.

Já soluções coloidais de prata podem ser distinguidas pela sua cor e pelo modo como esta dispersa a luz visível. Estas soluções são compostas por átomos neutros de prata que formam aglomerados (ou clusters) de diversas formas e tamanhos. Em geral, os clusters são, aproximadamente esféricos. Sua forma está claramente ligada ao número de átomos que os formam.

Os aglomerados de prata são formados devido ao caráter hidrofóbico da prata metálica $\left(\mathrm{Ag}^{0}\right)$. Como resultado direto desse fato, uma camada de íons de hidrogênio $\left(\mathrm{H}^{+}\right)$envolve os clusters, essa foi chamada de Camada de Stern. Uma segunda camada, mista de íons positivos e negativos engloba o cluster e a camada Stern, a união de ambas camadas citadas dá origem à Teoria da Dupla Camada, proposta por Derjaquin, Landau, Verwey, e Overbeek na primeira metade do século XX. Entre essas duas camadas, existe uma carga eletrostática em constante movimento, chamada de potencial Zeta. No caso dos clusters de prata, esse potencial pode alcançar valores próximos de - $100 \mathrm{mV}$ (Laroo, 2013 assim como a Figura 1).

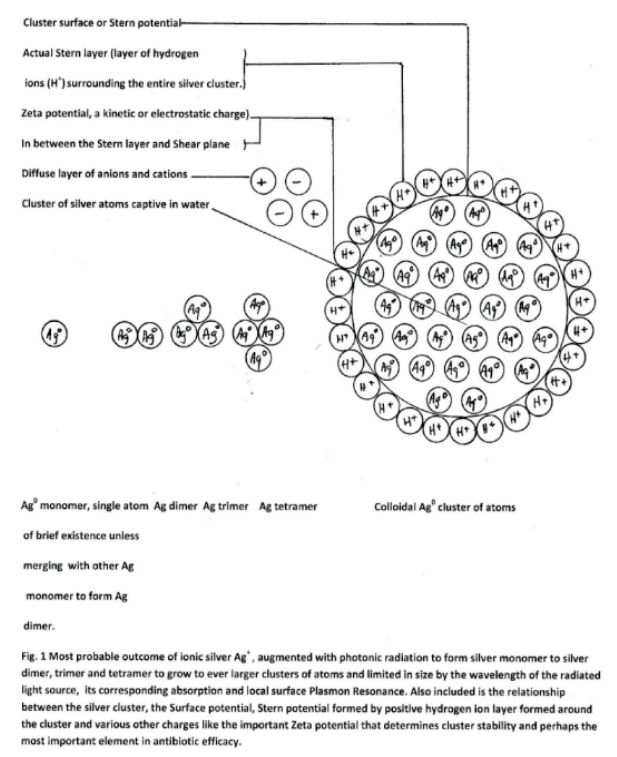

Figura 1 - Representação de um Cluster de prata carregado em Solução Aquosa 


\subsection{Vulnerabilidade Solução Coloidal De Prata Em Suspensão}

Ao contrário do que diz o senso comum, as soluções coloidais de prata não são formadas por nanopartículas de prata pura, mas sim por "nano-aglomerados" de átomos (mostrados no item anterior). Todos esses aglomerados possuem tamanho semelhante e, portanto, carga elétrica semelhante (e de mesmo sinal). Essas cargas geram uma repulsão entre os clusters, que resultará em um alto módulo de potencial Zeta. Quando esse potencial supera, em valor absoluto, àquele causado pelas forças de Van der Waals (cerca de $25 \mathrm{mV}$ ), essas forças perdem a relevância se comparadas às outras que ali agem e a matéria entra em suspensão. $O$ alto potencial Zeta, que está associado à ação repulsiva mútua dos clusters de prata coloidal, garante à solução certa estabilidade a longo prazo.

A prata coloidal é suscetível e vulnerável a diversos agentes externos como calor, ondas infravermelhas, micro-ondas e até mesmo ao bombardeamento por raios de luz com altos comprimentos de onda (como verde, amarelo, vermelho e laranja). A temperatura, por exemplo, aumenta a energia de cada cluster, causando maior agitação desse, isso diminui a ação relativa das forças de repulsão entre os clusters. Tal diminuição pode fazer com que "clusters vizinhos" se aproximem demais ou se choquem, formando clusters maiores. Esse aumento pode chegar a um ponto limítrofe em que a gravidade se encarrega de decantar a prata e assim, tirá-la de suspensão.

Também não é recomendável a utilização de soluções de prata iônica juntamente com os coloides dessa mesma substância. Os cátions $\mathrm{Ag}^{+}$terão papel semelhante ao da temperatura, eles aproximarão os "clusters vizinhos", pois a presença de íons positivos entre os aglomerados reduzirá a repulsão relativa entre eles, fazendo com que a solução se torne mais sensível.

\subsection{A Escolhada Prata}

A motivação para o presente trabalho consiste no tratamento de feridas de pele em um cão portador de duas doenças autoimunes. Sabendo disso, pesquisamos que a bactéria Pseudomonas aeruginosa é um dos principais microrganismos responsáveis por infecções de feridas e queimaduras de pele.

A prata coloidal apresenta ação contra uma ampla faixa de microrganismos com bactérias (principalmente gram-negativas) e fungos. Serão realizados testes em colônias de bactérias Pseudomonas aeruginosa, Escherichia colie Staphylococcus aureus. Além da prata, muitos outros metais foram estudados, resultando na escala de toxicidade contra microrganismos (Berni et al, 2008) a seguir:

$$
\mathrm{Ag}>\mathrm{Hg}>\mathrm{Cu}>\mathrm{Cd}>\mathrm{Pb}>\mathrm{Co}>\mathrm{Au}>\mathrm{Zn}>\mathrm{Fe}>\mathrm{Mn}>\mathrm{Mo}>\mathrm{Sn}
$$


Outros metais que poderiam ser utilizados, e têm seu efeito bactericida comprovado, seriam o Mercúrio e o Cobre. Porém, os colóides de mercúrio sintetizados se mostraram extremamente tóxicos às células animais, enquanto os de cobre não são tão efetivos contra as bactérias.

Em decorrência da resistência a antibióticos, causada pela seleção de microrganismos mais resistentes, os estudos sobre novos fármacos vêm sendo estimulados. Compostos contendo prata têm se tornado muito populares na medicina moderna.

\subsection{Ação Das Nanopartículas De Prata}

Como dito anteriormente, a prata desperta grande interesse nas pesquisas em áreas medicinais devido à ação bactericida e fungicida da mesmana forma iônica. Recentes estudos mostram que soluções de nanopartículas de prata possuem alta atividade antimicrobiana, assim como soluções de prata iônica.

Entre outras nanopartículas metálicas já sintetizadas anteriormente, a prata e o cobre, segundo estudos, foram os mais eficientes na relação custo-desempenho, porém a eficiência do cobre foi menor. Ainda assim, a ação antimicrobiana da nano-prata não é completamente compreendida. Mas muitos cientistas acreditam que alguns mecanismos semelhantes àqueles de soluções iônicas de prata também atuam nem suas soluções coloidais.

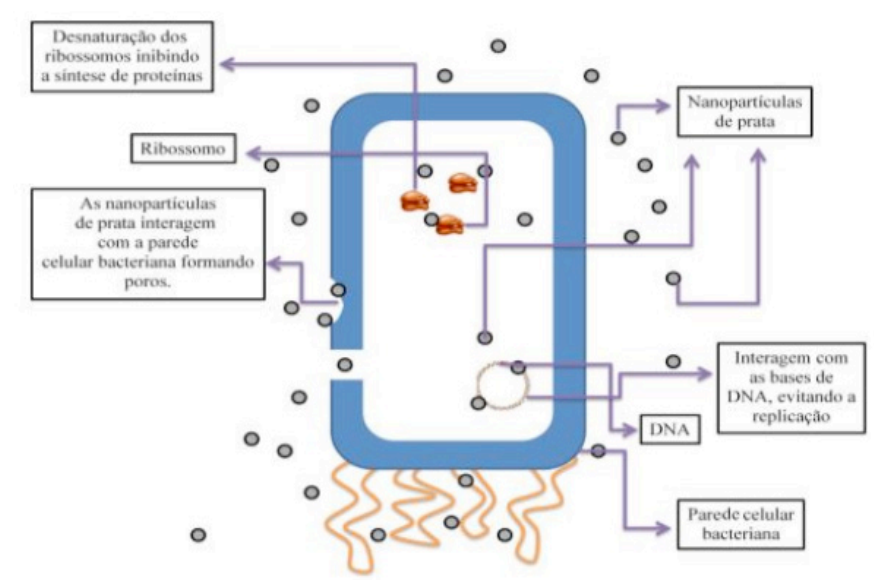

Figura 2 - Mecanismos da Ação da Atividade Microbiana das Nanopartículas de Prata

Alguns efeitos conhecidos das nanopartículas de prata em células bacterianas e de fungos podem ser observados na Figura 2 (De Sá, 2015). Pode-se afirmar que a ligação destas partículas na célula depende da área superficial disponível para a interação (Morones et al., 2005). São 3 as principais interações possíveis conhecidas. 
A primeira ocorre quando as nanopartículas interagem com proteínas presentes na membrana plasmática, deformando-a e causando problemas de permeabilidade na célula. Caso a concentração seja alta o suficiente, as nanopartículas de prata se depositarão nas membranas e nas paredes celulares (quando houver) podendo ocasionar lise das mesmas.

Em concentrações significativamente mais baixas, essas não se depositarão nas membranas e haverá uma massiva passagem de clusters para o meio intracelular, sem danificar (muito) a membrana.

Uma vez dentro das células, as nanopartículas de prata podem interagir com o DNA, fazendo com que esse se desnature e tornando a sua replicação impossível (impede a divisão celular). Mais especificamente, o metal desloca as ligações de hidrogênio entre os nitrogênios adjacentes de bases purinas e pirimidinas, impedindo posterior replicação (por causa da alta afinidade da prata com os grupos fosfatos dos nucleotídeos).

A terceira possibilidade se mostra quando as nanopartículas de prata interagem com os ribossomos. Tal interação leva ao comprometimento da síntese de proteínas fundamentais para a respiração celular, causando a morte celular por falta de energia.

Já foi comprovada a grande afinidade das nanopartículas de prata com grupos químicos que possuem os elementos enxofre e fósforo. Ambos são encontrados nas membranas e no interior de células bacterianas (no DNA, por exemplo), quando em concentrações suficientes, as nanopartículas danificam as estruturas celulares que contenham maior quantidade de enxofre e/ou fósforo.

Outras interações devem-se ao fato de a Nanoprata ter a capacidade de gerar superóxidos (Radicais Livres), assim como o íon $\mathrm{Ag}^{+}$. Tal geração foi comprovada pois a adição de antioxidantes reduz o efeito bactericida das soluções de nanopartículas de prata (Laroo, 2013). Os radicais livres, aqui citados, provavelmente são provenientes da superfície de íons de hidrogênio $\left(\mathrm{H}^{+}\right)$em contato com os clusters.

Além do efeito bactericida e fungicida das soluções de prata coloidal, vale ressaltar que essa também provoca um efeito bacteriostático residual, isto é, conferirá aos locais impregnados com nanopartículas de prata uma proteção contra posterior proliferação de microrganismos.

\subsection{Utilizações Para Soluções De Nanopartículas De Prata}

Além das aplicações medicinais já citadas, soluções de nanopartículas de prata já são hoje utilizadas em outras áreas. Devido ao seu tamanho, as nanopartículas são facilmente incorporadas em muitos materiais, portanto é relativamente fácil impregná-los com estas nanopartículas.

Por todos estes motivos, elas já vêm sendo utilizadas em diversas aplicações 
por exemplo: em palmilhas anatômicas antimicrobianas com o intuito de evitar odores, em purificadores de ar, na esterilização de instrumentos cirúrgicos e até mesmo em curativos comerciais (band-aid's) que, apesar de ainda superfaturados, ajudam na cicatrização ao prevenir infecções. Bioquímicos suíços estão estudando a capacidade da prata para interromper a divisão celular do HIV em diversos estágios. As nanopartículas de prata vêm tomando o lugar dos íons cloreto em tratamentos mais modernos de água e alimentos.

\section{I ETAPA LABORATORIAL SÍNTESE DE NANOPRATA}

\subsection{Análises E Resultados Parciais}

\subsubsection{Síntese Eletrolítica De Prata Coloidal}

Optou-se por sintetizar prata coloidal eletroquimicamente pois foi a maneira mais simples e barata de obter tal produto. A cuba eletrolítica utilizada em todos os experimentos contém água deionizada e os eletrodos são de prata com $99.997 \%$ de pureza. Os eletrodos foram expostos a uma tensão constante de $24 \mathrm{~V}$ durante as eletrólises. Todos os experimentos a seguir contaram com agitação magnética da solução simultaneamente à eletrólise. Com exceção dos experimentos em que a temperatura inicial da água é menor ou igual a $10^{\circ} \mathrm{C}$ (Experimento 11 e 12), a frutose foi adicionada quando a solução atingia uma faixa entre $60^{\circ} \mathrm{C}$ a $70^{\circ} \mathrm{C}$ e o aquecedor era desligado. 


\begin{tabular}{|l|c|c|c|c|c|c|}
\hline Propriedade Estudada & E1 & E2 & E3 & E4 & E5 & E6 \\
\hline Eletrodo Utilizado Vermelho & $\mathrm{l}$ & 2 & $\mathrm{l}$ & 2 & 3 & 4 \\
\hline Massa Inicial Eletrodo Verm & $3,3100 \mathrm{~g}$ & $3,3098 \mathrm{~g}$ & $3,040 \mathrm{~g}$ & $3,234 \mathrm{~g}$ & $3,333 \mathrm{~g}$ & $3,344 \mathrm{~g}$ \\
\hline Massa Final Eletrodo Verm & $3,3084 \mathrm{~g}$ & $3,2445 \mathrm{~g}$ & $3,2618 \mathrm{~g}$ & $1,745 \mathrm{~g}$ & $3,289 \mathrm{~g}$ & $3,289 \mathrm{~g}$ \\
\hline Eletrodo Utilizado Preto & 2 & 1 & 2 & 1 & 4 & 3 \\
\hline Massa Inicial Eletrodo Preto & $3,3092 \mathrm{~g}$ & $3,3084 \mathrm{~g}$ & $3,2350 \mathrm{~g}$ & $3,177 \mathrm{~g}$ & $3,345 \mathrm{~g}$ & $3,289 \mathrm{~g}$ \\
\hline Massa Final Eletrodo Preto & $3,3098 \mathrm{~g}$ & $3,3089 \mathrm{~g}$ & $3,2300 \mathrm{~g}$ & $2,999 \mathrm{~g}$ & $3,344 \mathrm{~g}$ & $2,473 \mathrm{~g}$ \\
\hline Tempo de Eletrólise & $1 \mathrm{~h}$ & $6 \mathrm{~h}$ & $6 \mathrm{~h}$ & $17 \mathrm{~h}$ & $<2 \mathrm{~h}$ & $21 \mathrm{~h}$ \\
\hline Temp Inicial da Água & $24,0{ }^{\circ} \mathrm{C}$ & $23,7{ }^{\circ} \mathrm{C}$ & $23,5{ }^{\circ} \mathrm{C}$ & $23,8^{\circ} \mathrm{C}$ & $23,8^{\circ} \mathrm{C}$ & $25,1^{\circ} \mathrm{C}$ \\
\hline Presença de Luz (+ ou -) & + & - & + & - & + & + \\
\hline Massa de Frutose / $\mathrm{H}_{2} \mathrm{O}$ & $1,0079 \mathrm{~g}$ & $1,0022 \mathrm{~g}$ & $1,0038 \mathrm{~g}$ & $1,0731 \mathrm{~g}$ & $0,650 \mathrm{~g}$ & $0 \mathrm{~g}$ \\
\hline Massa de Na2CO$/ \mathrm{L} \mathrm{H}_{2} \mathrm{O}$ & $0 \mathrm{~g}$ & $0 \mathrm{~g}$ & $1,0052 \mathrm{~g}$ & $0,520 \mathrm{~g}$ & $0,502 \mathrm{~g}$ & $0,511 \mathrm{~g}$ \\
\hline Condutividade & - & - & $-158,8 \mathrm{mV}$ & $-131,9 \mathrm{mV}$ & $-113,7 \mathrm{mV}$ & - \\
\hline pH da Solução Final & - & - & 9,82 & 9,51 & 9,00 & 9,30 \\
\hline Medidor de Partículas & - & - & $109 \mathrm{ppm}$ & $604 \mathrm{ppm}$ & $476 \mathrm{ppm}$ & $488 \mathrm{ppm}$ \\
\hline
\end{tabular}

\begin{tabular}{|l|c|c|c|c|c|c|}
\hline Propriedade Estudada & E7 & E8 & E9 & E10 & E11 & E12* \\
\hline Eletrodo Utilizado Vermelho & 4 & 5 & 5 & 2 & 6 & 5 \\
\hline Massa Inicial Eletrodo Verm & $3,289 \mathrm{~g}$ & $5,365 \mathrm{~g}$ & $5,215 \mathrm{~g}$ & $2,344 \mathrm{~g}$ & $5,371 \mathrm{~g}$ & $5,175 \mathrm{~g}$ \\
\hline Massa Final Eletrodo Verm & - & $5,215 \mathrm{~g}$ & $5,175 \mathrm{~g}$ & - & $5,278 \mathrm{~g}$ & $5,076 \mathrm{~g}$ \\
\hline Eletrodo Utilizado Preto & 3 & 6 & 2 & 5 & 5 & 6 \\
\hline Massa Inicial Eletrodo Preto & $2,247 \mathrm{~g}$ & $5,372 \mathrm{~g}$ & $2,345 \mathrm{~g}$ & $5,176 \mathrm{~g}$ & $5,176 \mathrm{~g}$ & $5,278 \mathrm{~g}$ \\
\hline Massa Final Eletrodo Preto & & & $2,344 \mathrm{~g}$ & $5,176 \mathrm{~g}$ & $5,175 \mathrm{~g}$ & $5,278 \mathrm{~g}$ \\
\hline Tempo de Eletrólise & $3 \mathrm{~h}$ & $3 \mathrm{~h}$ & $1 \mathrm{~h}$ & $1 \mathrm{~h}$ & $1,5 \mathrm{~h}$ & $45 \mathrm{~min}$ \\
\hline Temp Inicial da Água & $26,1^{\circ} \mathrm{C}$ & $25,7{ }^{\circ} \mathrm{C}$ & $24,7{ }^{\circ} \mathrm{C}$ & $24,2{ }^{\circ} \mathrm{C}$ & $8{ }^{\circ} \mathrm{C}$ & $25,2{ }^{\circ} \mathrm{C}$ \\
\hline Presença de Luz (+ou -) & - & - & - & - & - & - \\
\hline Massa de Frutose / $\mathrm{L} \mathrm{H}_{2} \mathrm{O}$ & $0,651 \mathrm{~g}$ & $0 \mathrm{~g}$ & $0,648 \mathrm{~g}$ & $0,075 \mathrm{~g}$ & $0,520 \mathrm{~g}$ & - \\
\hline Massa de Na $2 \mathrm{CO}_{3} / \mathrm{L} \mathrm{H}_{2} \mathrm{O}$ & $0,502 \mathrm{~g}$ & $0,530 \mathrm{~g}$ & $0,498 \mathrm{~g}$ & $0,499 \mathrm{~g}$ & $0,507 \mathrm{~g}$ & $0,518 \mathrm{~g}$ \\
\hline Condutividade Solução Final & $-169,1 \mathrm{mV}$ & $-163,1 \mathrm{mV}$ & $-178,3 \mathrm{mV}$ & $-170,1 \mathrm{mV}$ & $-159,9 \mathrm{mV}$ & $-155,4 \mathrm{mV}$ \\
\hline pH da Solução Final & 9,89 & 9,67 & 10,17 & 10,22 & 9,78 & 9,01 \\
\hline Medidor de Partículas & $443 \mathrm{ppm}$ & $710 \mathrm{ppm}$ & $485 \mathrm{ppm}$ & $481 \mathrm{ppm}$ & $312 \mathrm{ppm}$ & $765 \mathrm{ppm}$ \\
\hline
\end{tabular}

Tabela 1 -Resultados experimentais dos testes de produção eletroquímica.

* O experimento 12 foi o primeiro com uma fonte de tensão variável, experimento realizado com 7 Volts

Após doze experimentos bem sucedidos, foi possível começar a entender os melhores parâmetros de síntese, como o intervalo de tempo e a quantidade de reagente que deve ser adicionada.

Posteriormente, o $\mathrm{LM}^{2} \mathrm{C}^{2}$ (Laboratório de Moagem de Alta Energia, Materiais, Carbono e Compósitos para Altas Temperaturas) adquiriu uma nova fonte de corrente contínua, em que é possível controlar a Voltagem/Corrente utilizada durante a síntese. Foram feitos alguns experimentos para que fosse estudado como as diferenças entre as fontes interferem a síntese.

Com a nova fonte também foi feito o teste com a água deionizada, isto é, foi preparada uma solução sem $\mathrm{Na}_{2} \mathrm{CO}_{3}$ e, independentemente do tempo exposto à diferença de potencial e da voltagem, não havia corrente passando pela solução, mostrando que a amostra é de boa qualidade e não contém quantidade significativa 
de íons na água. Os experimentos precedidos pela sigla NF, são aqueles feitos pela fonte nova.

\begin{tabular}{|c|c|c|c|c|c|c|}
\hline Propriedade Estudada & NF1 & NF2 & NF3 & NF4 & NF5 & NF6 \\
\hline Eletrodo Utilizado Vermelho & 5 & 6 & 6 & 6 & 5 & 5 \\
\hline Massa Inicial Eletrodo Verm & $5,072 \mathrm{~g}$ & $5,297 \mathrm{~g}$ & $5,122 \mathrm{~g}$ & $5,035 \mathrm{~g}$ & $4,367 \mathrm{~g}$ & $4,248 \mathrm{~g}$ \\
\hline Massa Final Eletrodo Verm & $4,430 \mathrm{~g}$ & $5,154 \mathrm{~g}$ & $5,035 \mathrm{~g}$ & $4,833 \mathrm{~g}$ & $4,248 \mathrm{~g}$ & $4,228 \mathrm{~g}$ \\
\hline Eletrodo Utilizado Preto & 6 & 5 & 5 & 5 & 6 & 6 \\
\hline Massa Inicial Eletrodo Preto & $5,277 \mathrm{~g}$ & $4,427 \mathrm{~g}$ & $4,366 \mathrm{~g}$ & $4,366 \mathrm{~g}$ & $4,831 \mathrm{~g}$ & $4,811 \mathrm{~g}$ \\
\hline Massa Final Eletrodo Preto & $5,297 \mathrm{~g}$ & $4,438 \mathrm{~g}$ & $4,366 \mathrm{~g}$ & $4,357 \mathrm{~g}$ & $4,811 \mathrm{~g}$ & $4,821 \mathrm{~g}$ \\
\hline Tempo de Eletrólise & $2 \mathrm{~h}$ & $1 \mathrm{~h}$ & $10 \mathrm{~min}$ & $2 \mathrm{~h}$ & $1 \mathrm{~h}$ & $15 \mathrm{~min}$ \\
\hline Temp Inicial da Água & $23,1^{\circ} \mathrm{C}$ & $22,7^{\circ} \mathrm{C}$ & $23,2^{\circ} \mathrm{C}$ & $22,8^{\circ} \mathrm{C}$ & $22,8^{\circ} \mathrm{C}$ & $23,6^{\circ} \mathrm{C}$ \\
\hline Volume de Água (Solvente) & $0,50 \mathrm{~L}$ & $0,55 \mathrm{~L}$ & $0,51 \mathrm{~L}$ & $0,50 \mathrm{~L}$ & $0,50 \mathrm{~L}$ & $0,51 \mathrm{~L}$ \\
\hline Tensão na Fonte & $8,03 \mathrm{~V}$ & $7,98 \mathrm{~V}$ & $8,00 \mathrm{~V}$ & $8,02 \mathrm{~V}$ & $5,21 \mathrm{~V}$ & $8,02 \mathrm{~V}$ \\
\hline Massa de Frutose & $0,251 \mathrm{~g}$ & $0 \mathrm{~g}$ & $0 \mathrm{~g}$ & $0 \mathrm{~g}$ & $0,330 \mathrm{~g}$ & $0 \mathrm{~g}$ \\
\hline Massa de $\mathrm{Na}_{2} \mathrm{CO}_{3}$ & $0,252 \mathrm{~g}$ & $0,255 \mathrm{~g}$ & $1,65 \mathrm{~g}$ & $0,110 \mathrm{~g}$ & $0,254 \mathrm{~g}$ & $0,261 \mathrm{~g}$ \\
\hline Condutividade Solução Final & $-140,77 \mathrm{mV}$ & $-154,17 \mathrm{mV}$ & $-160,33 \mathrm{mV}$ & $-180,98 \mathrm{mV}$ & $-169,27 \mathrm{mV}$ & $-170,34 \mathrm{mV}$ \\
\hline pH da Solução Final & 9,21 & 9,55 & 9,78 & 9,24 & 10,17 & 10,05 \\
\hline Medidor de Partículas & - & - & - & - & - & - \\
\hline
\end{tabular}

Tabela 2-Resultados experimentais com a nova fonte de corrente contínua.

Com esses experimentos, foi possível concluir que o resultado final das sínteses está diretamente ligado à corrente que passa pela solução durante o período de síntese, "independente" da massa de $\mathrm{Na}_{2} \mathrm{CO}_{3}$. Isto é, o resultado está vinculado na relação entre as massas de água, de $\mathrm{Na}_{2} \mathrm{CO}_{3}$ e de frutose que dão à solução uma resistência elétrica praticamente constante. Durante a síntese, são formados os aglomerados de nanopartículas de prata envolvidos por uma camada de íons $\mathrm{H}+$, que alteram a resistência da solução.

Tendo como base os sete experimentos anteriores, foi feito um planejamento dos próximos experimentos com base na técnica de Ensaios Direcionados, conhecida em inglês como Design of Experiments (DoE). Isto é, estudar o processo identificando os fatores que mais influenciam na síntese de nanopartículas de prata pela via eletrolítica, com o intuito de otimizá-la.

A seguir, estão explicitados os parâmetros de síntese que foram considerados para os nove experimentos DoE (Design of Experiments).

\begin{tabular}{|c|c|c|}
\hline \multicolumn{3}{|c|}{ Numbered Parameters for DoE } \\
Experiments
\end{tabular}

Os experimentos que seguiram tal linha de raciocínio foram precedidos da sigla: 
DoE. Foram, feitos nove experimentos seguindo a teoria de ensaios direcionados, com os seguintes parâmetros:

\begin{tabular}{|c|c|c|c|c|c|}
\hline DoE 1 & $1,1,1,1$ & $\operatorname{DoE} 4$ & $2,1,2,3$ & $\operatorname{DoE} 7$ & $3,1,3,2$ \\
\hline DoE 2 & $2,1,1,1$ & $\operatorname{DoE} 5$ & $2,2,3,1$ & $\operatorname{DoE} 8$ & $3,2,1,3$ \\
\hline DoE 3 & $1,3,3,3$ & $\operatorname{DoE} 6$ & $2,3,1,2$ & $\operatorname{DoE} 9$ & $3,3,2,1$ \\
\hline
\end{tabular}

Entre os nove novos experimentos feitos, os que visualmente tiveram melhores resultados foram os DoE 2 e DoE 3 e foram caracterizados como "ótimos".

\section{I GALERIA DE FOTOS NANOPARTÍCULAS SINTETIZADAS}

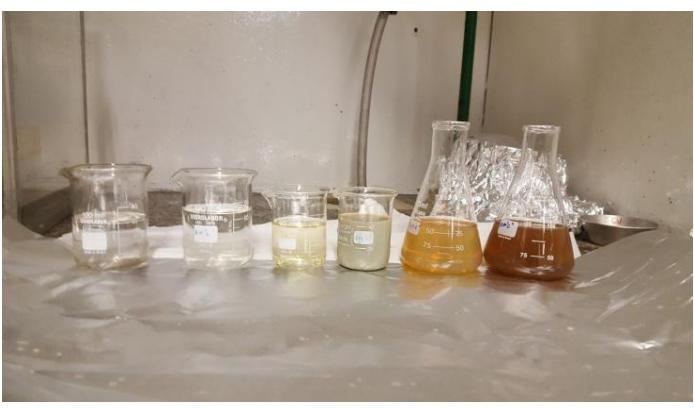

Figura 3 - Experimentos 1 a 6 ordenados da esquerda p/ direita.

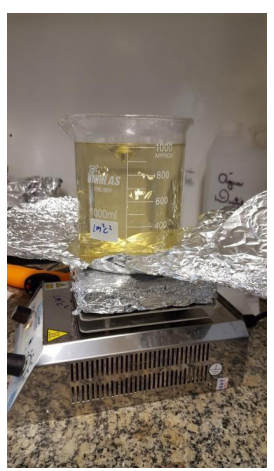

Figura 5 - Amostra Final do Experimento 3

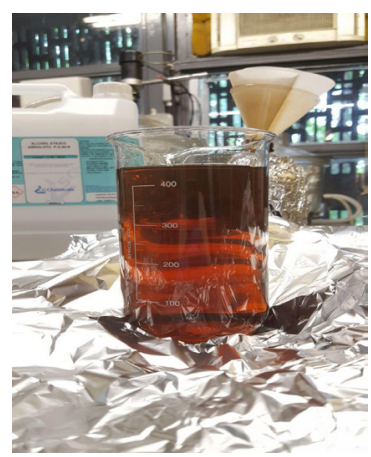

Figura 4- DoE 3 Logo após sua síntese.

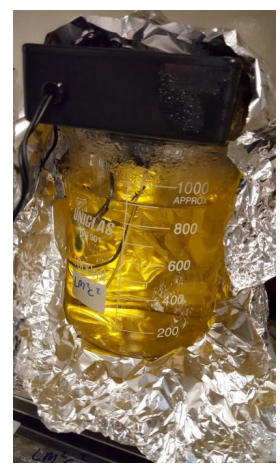

Figura 6 - Experimento 5 depois de $1.5 \mathrm{~h}$ de Síntese 


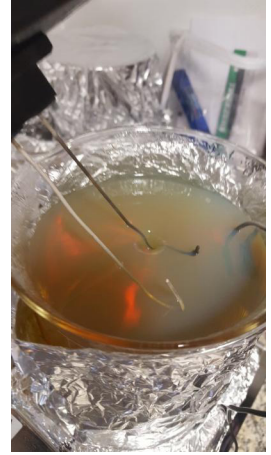

Figura 7 - Experimento 4 depois de $4 \mathrm{~h}$ de Síntese

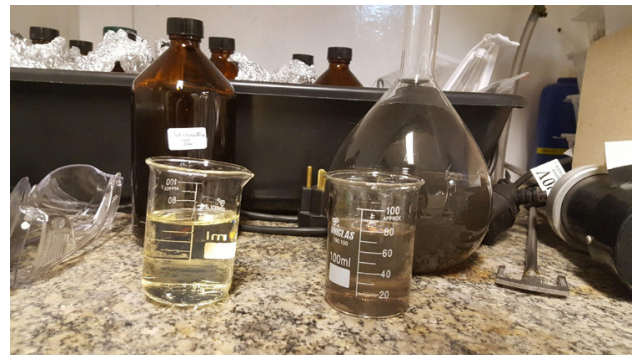

Figura 9 - Experimento 3 depois de 130 dias e Experimento 11 depois de 90 dias

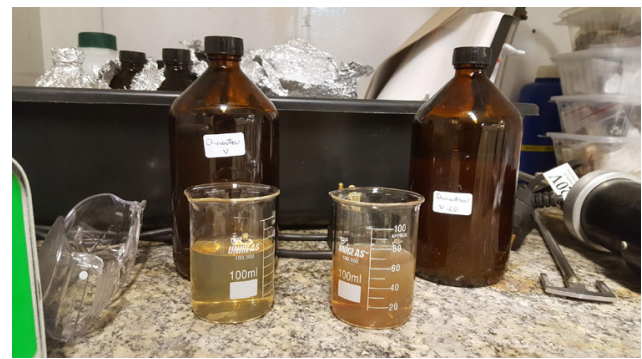

Figura 11 - Experimento 5 depois de 120 dias e Experimento 5.2 depois de 90 dias.

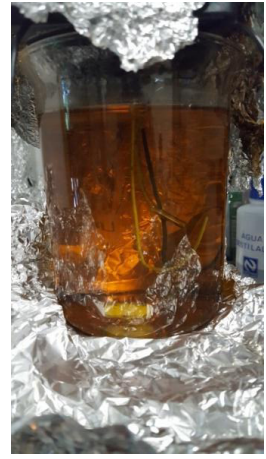

Figura 8 - Amostra Final do Experimento 6

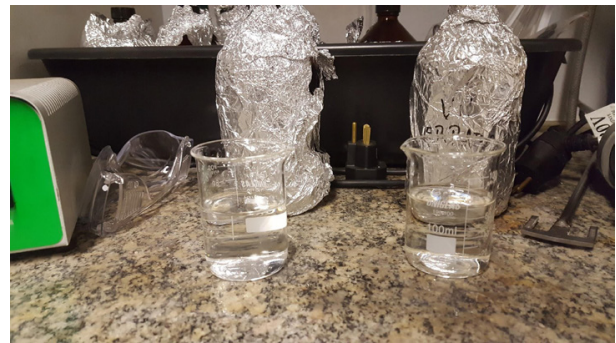

Figura 10 - Experimentos 6 e 7 depois de aproximadamente 120 dias.

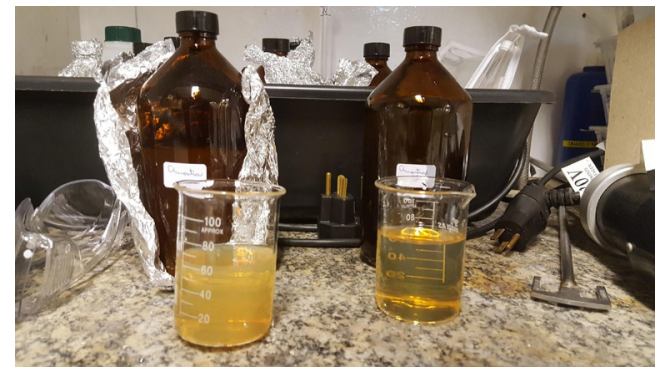

Figura 12 - Experimento 9 e 10 depois de 90 dias.

\section{I ANÁLISE DO TAMANHO, DISTRIBUIÇÃO E COMPOSIÇÃO DAS NANOPARTÍCULAS DE PRATA}

Nos testes de medição do diâmetro das nanopartículas, foi utilizado o Zetasizer Nano S, em que mede-se o diâmetro de partículas entre $0.3 \mathrm{~nm}$ e $10 \mu \mathrm{m}$. Além dos ensaios de medição, foram feitos ensaios para caracterização da solução por meio de técnicas de microscopia de varredura de alta resolução (Microscópio MEV). Todos os ensaios foram feitos em triplicatas e serão expostos os resultados médios obtidos. 


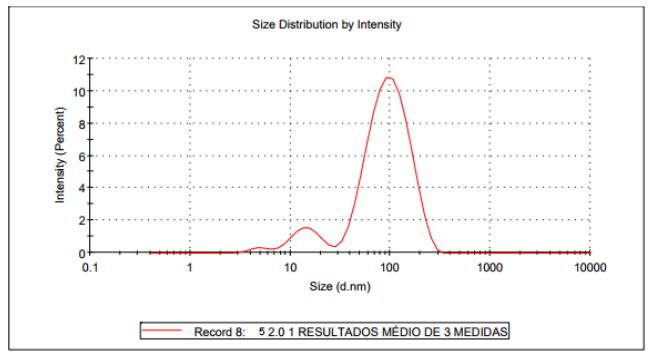

Gráfico 1 - Distribuição de diâmetro da Amostra 5.2

Maio de 2017

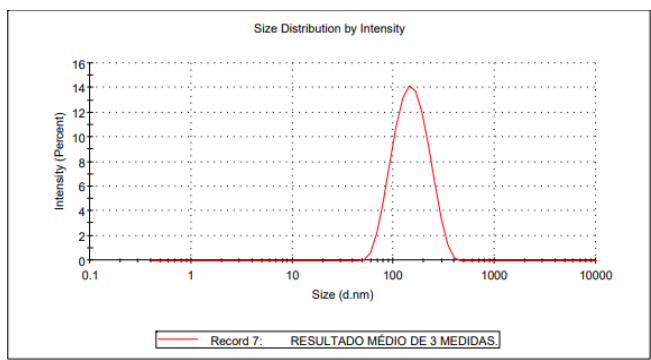

Gráfico 3 - Distribuição de diâmetro da amostra 11

Maio de 2017

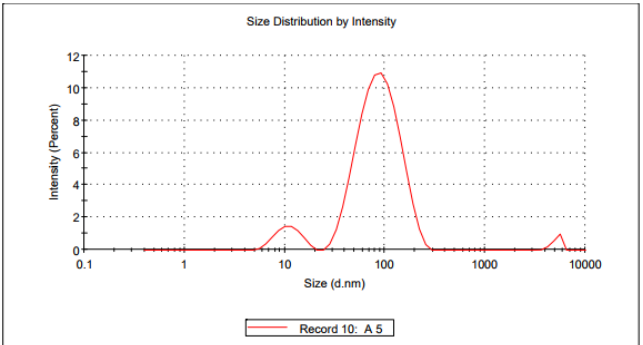

Gráfico 2 -Distribuição do diâmetro da Amostra 5

Maio de 2017

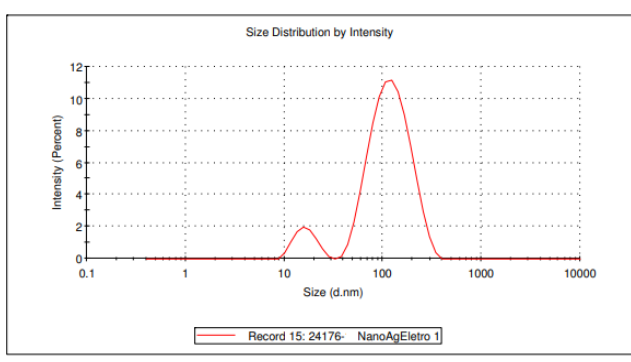

Gráfico 4 - Distribuição de diâmetro da Amostra 5.2

Janeiro 2017

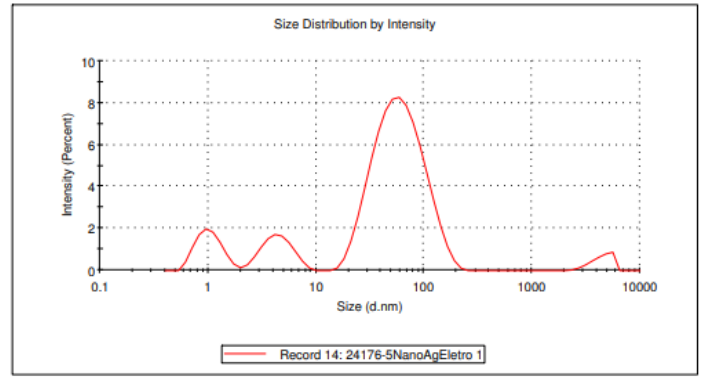

Gráfico 5 - Distribuição de diâmetro da Amostra DoE 1

\begin{tabular}{|c|c|c|c|}
\hline Amostra & $\begin{array}{l}\text { Diâmetros dos Clusters } \\
\qquad(\mathrm{nm})\end{array}$ & $\begin{array}{l}\text { Porcentagem } \\
\text { das Partículas }\end{array}$ & Diâmetro Médio $(\mathrm{nm})$ \\
\hline \multirow{2}{*}{$\begin{array}{c}\text { Gráfico } 1 \\
\text { (A 5.2) Maio } 2017\end{array}$} & $104,61 \mathrm{~nm}$ & $89,3 \%$ & \multirow[b]{2}{*}{$61,78 \mathrm{~nm}$} \\
\hline & $15,10 \mathrm{~nm}$ & $9,4 \%$ & \\
\hline \multirow{2}{*}{$\begin{array}{c}\text { Gráfico } 2 \\
\text { (A 5) Maio } 2017\end{array}$} & $94,36 \mathrm{~nm}$ & $90,6 \%$ & \multirow[b]{2}{*}{$62,58 \mathrm{~nm}$} \\
\hline & $11,10 \mathrm{~nm}$ & $7,7 \%$ & \\
\hline $\begin{array}{c}\text { Gráfico } 3 \\
\text { (A 11) Maio } 2017\end{array}$ & $157,80 \mathrm{~nm}$ & $100 \%$ & $135,7 \mathrm{~nm}$ \\
\hline \multirow{2}{*}{$\begin{array}{c}\text { Gráfico } 4 \\
\text { (A 5.2) Janeiro } 2018\end{array}$} & $128,91 \mathrm{~nm}$ & $91,0 \%$ & \multirow[b]{2}{*}{$81,79 \mathrm{~nm}$} \\
\hline & $16,66 \mathrm{~nm}$ & $9,0 \%$ & \\
\hline \multirow{3}{*}{$\begin{array}{c}\text { Gráfico } 5 \\
\text { (DoE 1) Janeiro } 2018\end{array}$} & $64,90 \mathrm{~nm}$ & $77,3 \%$ & \multirow{3}{*}{$50,71 \mathrm{~nm}$} \\
\hline & $4,53 \mathrm{~nm}$ & $9,9 \%$ & \\
\hline & $1,06 \mathrm{~nm}$ & $9,9 \%$ & \\
\hline
\end{tabular}

Tabela -Resultados Médios dos Ensaios no Zeta Sizer. 


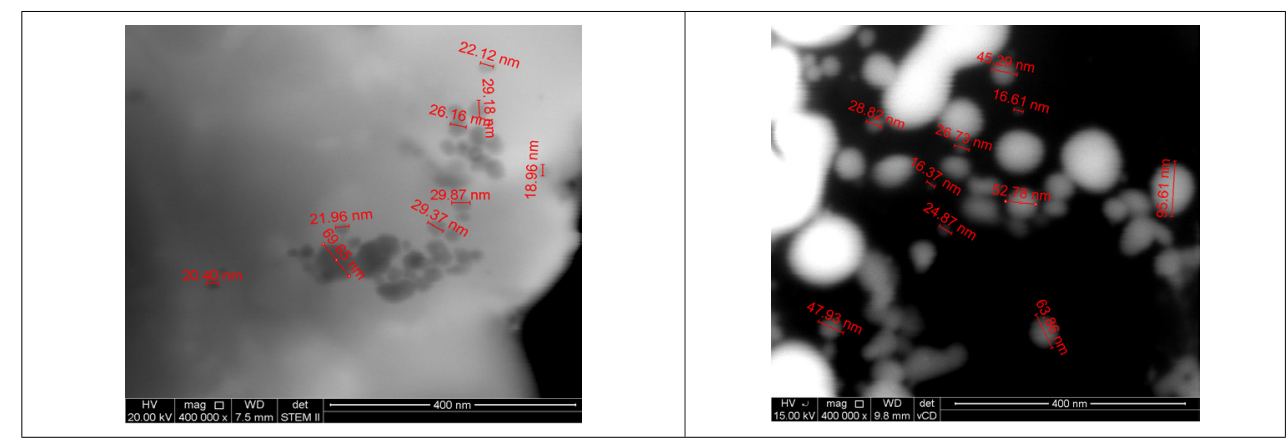

Figura 13 e 14 - Imagens da Microscopia Eletrônica proveniente das amostras 5 e 5.2 respectivamente.

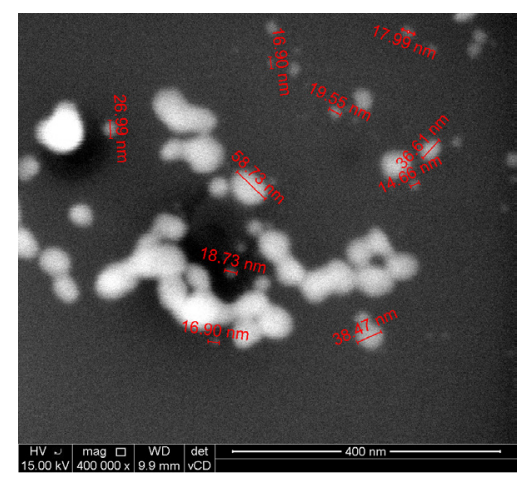

Figura 14 - Imagem de Microscopia Eletrônica proveniente da amostra 11.

Foram realizadas análises químicas das substâncias presentes nas soluções e, conforme esperado, sódio e prata foram os mais abundantes seguido de carbono, proveniente do filme utilizado na microscopia.

\section{I ANÁLISE DO EFEITO BACTERICIDA E BACTERIOSTÁTICO DAS SOLUÇÕES DE NANOPARTÍCULAS DE PRATA}

Também foram realizados testes in vitro com as soluções de nanopartículas de prata sintetizadas tanto pela rota química quanto pela rota eletroquímica, e também com outros constituintes do creme. A seguir seguem fotos de alguns testes realizados.

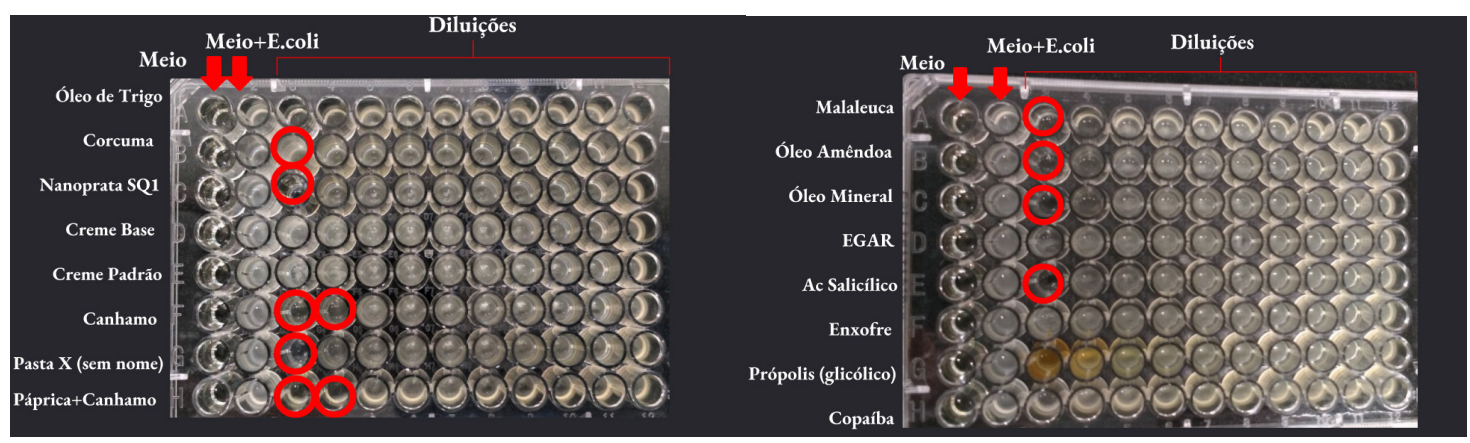




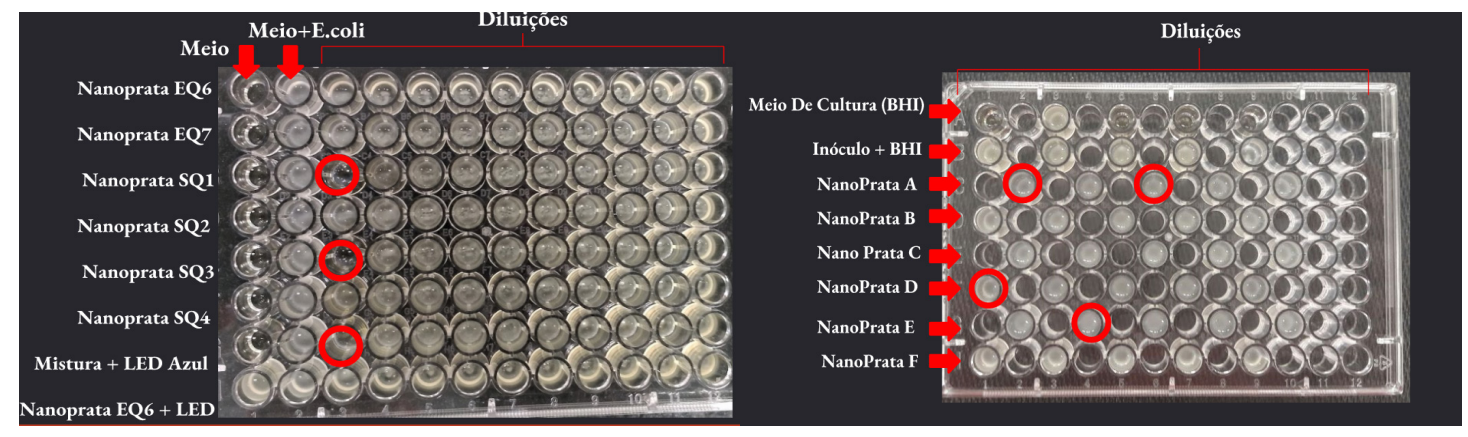

A olho nu é possível observar a transparência das soluções e comparativamente, pode-se perceber a turbidez das soluções mostrando que as células bacterianas sofreram lise ao estarem em contato com a NanoPrata ou com outros constituintes do creme. Além disso, foram feitos ensaios com a irradiação de luz nas soluções. Também foram feitos ensaios de absorbância (Anexo 1) que comprovam o efeito bactericida dos mesmos. Os testes foram feitos no Laboratório de Biofotônica da Uninove pelo co-orientador deste trabalho, Rodrigo Labat.

É possível concluir, analisando a tabela de absorbância, que as soluções de nanopartículas de prata possuem efeitos bactericidas. Novos testes foram feitos com o intuito de comprovar a ativação por luz das soluções de nanopartículas de prata.

\section{I DISCUSSÃO DOS RESULTADOS PARCIAIS}

A síntese por via eletroquímica se mostrou eficiente e possível. Nos casos de sucesso, pode-se observar uma estabilidade grande. Um exemplo disso é a Amostra 5.2, em que foi analisada na época de síntese e nove meses depois. Pelos resultados do Zeta Sizer, é possível notar um pequeno crescimento médio das nanopartículas devido a pequenos choque e aglomerações entre os clusters em suspensão. Porém, para nove meses armazenada (sem a presença de luz e temperatura entre $15^{\circ} \mathrm{C}$ e $25^{\circ} \mathrm{C}$ ), a solução se mostrou muito estável.

Quanto ao efeito bactericida, os testes in vitro comprovaram esse efeito, tendo uma melhor eficácia quando irradiados por luz visível de comprimentos de onda entre o azul e o vermelho.

Além disso, a confiabilidade das sínteses eletroquímica são baixas, isto é, pequenas imprecisões de medidas e quantidade, além da esperada transformação dos eletrólitos afetam drasticamente o resultado final. Foi percebido que eletrodos novos e semi-novos promovem maior confiabilidade à síntese. A luz também foi um fator influente, as sínteses armazenadas sem proteção à luz permaneceram estáveis por menos tempo, o mesmo foi notado para as amostras cujas sínteses foram realizadas sob o efeito de luz branca. 


\section{I CRONOGRAMA/RECOMENDAÇÃO DE CONTINUIDADE DA PESQUISA}

Como continuidade do projeto de pesquisa, recomenda-se seguir com os testes in vitro das soluções do creme, aliado, ou não, ao uso de luz Ultravioleta (e outros comprimentos de onda entre o vermelho e o azul), dando continuidade aos estudos da relação sinérgica das nanopartículas de prata e da luz em diferentes comprimentos de onda. Além de focar a atenção à síntese química das nanopartículas, que se mostrou mais estável, confiável e suas partículas mais uniformes.

Após as sínteses de amostras dos cremes, recomenda-se que sua liberação na corrente sanguínea e sua permeação cutânea na epiderme humana e canina sejam estudadas pelo equipamento denominado Célula de Franz. O objetivo é que as nanopartículas não sejam tão absorvidas pela pele e permaneçam em suas camadas mais superficiais, uma vez que pretende-se atingir feridas com o efeito bactericida.

Porém, caso ocorra pequenas absorções cutâneas ou ingestão (em animais), a literatura nos mostra que nanopartículas com diâmetros menores que 150 nm e hidrofóbicas são rapidamente eliminadas da corrente sanguínea por linfócitos. Além disso, por ser tratar da substância prata, os efeitos adversos de sua absorção seriam mínimos em mamíferos. Testes de Ensaio Cometa também são recomendados para avaliar o dano causado pelas nanopartículas de prata ao DNA das bactérias estudadas.

Por último, também são recomendados testes para definirmos a Janela Terapêutica do creme, isto é definirmos até que ponto as nanopartículas de prata possuem efeitos terapêuticos e não tóxicos às células humana e canina, definindo então uma espécie de IC-50 para as bactérias já citadas e seu Índice de Seletividade em relação às células humanas.

\section{REFERÊNCIAS}

KING, R. B. "Encyclopedia of Inorganic Chemistry", ed. John Wiley and Sons Ltd, United States, 1994.

HNILICA, K. A; “Dermatologia de Pequenos Animais”, 3ª edição, ed. Elsevier Brasil, Brasil 2011.

TOMA, H. E., "Nanotecnologia Molecular - Materiais e Dispositivos", Coleção de Química Conceitual, ed. Blucher, Brasil, 2016.

HUANG, A. A; MOORE G. E; SCOTT-MONCRIEFF J. C; "Idiopathic Immune-Mediated Thrombocytopenia and Recent Vaccination in Dogs", Purdue University, Estados Unidos, 2011.

TNS - Antimicrobianos e Nanotecnologia para Indústria, artigo "Prata: O Antimicrobiano usado há centenas de anos", Brasil, 2012

BURROWS, A; HOLMAN, J; PARSONS, A; PILLING, G; PRICE, G; "Química ${ }^{3}$, Introdução à química inorgânica, orgânica e físico-química", ed. LTC, Brasil, 2012. 
NELSON, D. L; COX, M. M; "Princípios de Bioquímica de Lehninger”, 6ª edição, ed. Artmed, Brasil, 2014.

LAROO, H; "Colloidal Nano Silver - Its Production Method, Properties, Standards and its Bio-Efficacy as an Inorganic Antibiotic", Austrália, 2013.

KIM, K. J; Sung, W. S; Moon, S. K; Choi, J. S; Kim, J. G; Dong, G. L; "Antifungal effect of silver nanoparticles on dermatophytes". J. Microbiol. Biotechnol, v.18, Kyungpook National University, Korea, 2008.

MORONES, J; ELECHIGUERRA, J; CAMACHO, A; HOLT, K; KOURI, J; RAMIREZ, J. T; YACAMAN, M. J; "The bactericidal effect of silver nanoparticles". University of Texas, Estados Unidos, 2005.

DE SÁ, S. R; “Inativação Fotodinâmica de Micro-Organismos Patogênicos Explorando Nanopartículas de Prata e Riboflavina". UFPE, Brasil, 2015. 


\section{TRANSFORMAÇÃO DE REJEITOS DE LAVAGEM DE BAUXITA DA AMAZÔNIA EM MATERIAL TIPO HIDROGROSSULAR (KATOITA) $\mathrm{DE} \mathrm{CA} \mathrm{FE}_{3} / \mathrm{AL}_{2}\left(\mathrm{OH}_{4}\right)_{3}$}

Data de aceite: 05/06/2020

Data de Submissão: 27/ 05/2020

Renata de Sousa Nascimento Universidade Federal do Oeste do Pará, Programa de Pós-graduação em Sociedade, Ambiente e Qualidade de Vida, Santarem-PA.

http://lattes.cnpq.br/1149710156702325

Bruno Apolo Miranda Figueira Universidade Federal do Oeste do Pará, Programa de Pós-graduação em Sociedade, Ambiente e Qualidade de Vida, Santarem-PA http://lattes.cnpq.br/6852513231905237 Andson Pereira Ferreira Instituto Federal de Educação, Ciência e Tecnologia do Pará, Parauapebas-PA http://lattes.cnpq.br/7360816759464936

RESUMO: Este trabalho propõea transformação dos rejeitos de lavagem de bauxita da região Oeste do estado do Pará. O processo de transformação envolveu dissolução do rejeito em ácido cloridríco e água na proporção (1:1), método da co-precipitação e tratamento hidrotermal a $80^{\circ} \mathrm{C}$. Os resultados revelaram que o rejeito de bauxita foi transformado com sucesso em hidrogrossular com estrutura análoga à katoita, com tamanho médio dos cristais de $5 \mu \mathrm{m}$ e morfologia em forma de octaédricos ligados uns aos outros. Os resultados aqui apresentados demonstram que os rejeitos de bauxita da Amazônia podem ser uma interessante fonte de baixo custo para a obtenção de produto de valor agregado.

PALAVRAS-CHAVE: rejeitos, bauxita, Amazônia, katoita.

\section{TRANSFORMATION OF BAUXITE-} WASHING RESIDUES FROM AMAZON INTO

HYDROGROSSULAR-TYPE MATERIAL (KATOITA) OF CA3FE/AL 2(OH4)3

ABSTRACT: This work proposes the transformation of bauxite washing waste from the western region of the state of Pará. The transformation process involved dissolving the waste in hydrochloric acid and water in the proportion (1: 1), co-precipitation method and hydrothermal treatment at $80^{\circ} \mathrm{C}$. The results revealed that the bauxite tailings were successfully transformed into hydrogrossular with a katoite-like structure, with an average crystal size of $5 \mu \mathrm{m}$ and morphology in the form of octahedrals connected to each other.

KEYWORDS: residues, bauxite, Amazon, katoite. 


\section{I INTRODUÇÃO}

A katoita, está inclusa na série dos minerais hidratados do grande grupo das granadas. Os minerais do grupo das granadas são silicatos formados por processos metamórficos de grau baixo a alto, cuja fórmula geral é $\mathrm{X}_{3} \mathrm{Y}_{2}\left(\mathrm{SiO}_{4}\right)_{3}$, sendo: $\mathrm{X}$, um cátions divalentes, por exemplo: $\mathrm{Ca}^{2+}, \mathrm{Mg}^{2+}, \mathrm{Mn}^{2+}$ e $\mathrm{Fe}^{2+}$, e $\mathrm{Y}$, um cátions trivalentes, como: $\mathrm{Al}^{3+}, \mathrm{Fe}^{3+}$ e $\mathrm{Cr}^{3+}$. Quando as séries grossular $\mathrm{Ca}_{3} \mathrm{Al}_{2}\left[\mathrm{SiO}_{4}\right]_{3} \mathrm{e}$ andradita $\mathrm{Ca}_{3} \mathrm{Fe}_{2}\left[\mathrm{SiO}_{4}\right]_{3}$, do grupo das granadas, sofrem processo de incorporação de hidrogênio a sua composição química é modificada, de modo que, os tetraedros de $\left[\mathrm{SiO}_{4}\right]_{3}$ são parcial ou completamente substituidos por tetraedros de $\left[(\mathrm{OH})_{4}\right]_{3}$, ou seja, os átomos de hidrogênios se ligam aos átomos de oxigênio que outrora estavam ligados ao silício, e portanto passam a ser chamados de hidrogrossular e hidroandratita, respectivamente (Klein \& Dutrow 2012; Dilnesa et al., 2014; Schoenitz et al., 1999).

Essas duas séries têm como membros finais o mineral chamado katoita, que terá composição química de alumínio $\mathrm{Ca}_{3} \mathrm{Al}_{2}(\mathrm{OH})_{12}$ ou ferro $\mathrm{Ca}_{3} \mathrm{Fe}_{2}(\mathrm{OH})_{12}$, respectivamente (Passaglia \& Rinaldi 1984). Essas fases minerais, inclusive a katoita, são comumentes encontradas em cimentos Portland hidratados e possuem alta relevância na construção civil, pois materiais à base de cimento hidratado podem servir para imobilizar resíduos radioativos de nível baixo a intermediário (Atkins e Glasser, 1992; Lacivita et al., 2015), e metais tóxicos, como o $\mathrm{Cr}^{6+}$, (Hillier et al., 2007), investigaram o potencial da katoita como fase hospedeira para $\mathrm{Cr}^{6+}$ advindo do processamento de minério de cromita e concluiram que houve a substituição de tetraedros de $\left[(\mathrm{OH})_{4}\right]_{3}$ por tetraedro de $\left[\mathrm{CrO}_{4}\right]^{2-}$.

Neste trabalho é proposta a síntese fácil e de baixo custo para a obtenção de katoita de alumínio e ferro, utilizando resíduos de lavagem de bauxita da Região Amazônica (Brasil), e possivelmente desenvolver um trabalho futuro com aplicação em áreas estratégicas como citadas acima.

\section{I MATERIAL E METÓDOS}

As amostras de rejeitos foram coletadas nos meses de setembro, outubro e novembro de 2012, sempre na primeira e na terceira semana de cada mês, totalizando 6 amostragens codificadas como JUR-1, JUR-2, JUR-3, JUR-4, JUR-5 e JUR-6. Todas as amostras passaram por processo de homogeinização e quarteamento e posteriormente uma amostragem chamada "estoque" foi separada e nomeada como (RBAUX) e caracterizada. A caracterização mineralógica foi realizada por difratometria de raios-X (DRX) em um difratômetro D2Phaser (Bruker), tubo de Cu $\left(1,5406 \AA\right.$ A), faixa de 5 a $75^{\circ}(2 \theta)$ com tensão de $30 \mathrm{kV}$ e $10 \mathrm{~mA}$. A caracterização 
química foi obtida em espectrômetro de Fluorescência de raios-X (FRX) Sequencial (Axios Minerals, da Panalytical), equipado com tubo de raios-x cerâmico anodo de $\mathrm{Rh}$.

Para a transformação do resíduo de lavagem de bauxita em katoita, ultilizouse cerca de $4 \mathrm{~g}$ de RBAUX que foram adicionados à solução de ácido clorídrico $(\mathrm{HCl})$ e água deionizada na proporção $(1: 1)$ e aquecidos a $100^{\circ} \mathrm{C}$ para obter uma solução rica em $\mathrm{Fe}^{3+}$, nomeada de solução $A$. A razão estequiométrica de $\mathrm{Ca} / \mathrm{Fe}$ ideal para a obtenção de katoita foi a (2:1) que correspondem aproximadamente $0,7 \mathrm{~g}$ de $\mathrm{CaCl}_{2} \cdot 6 \mathrm{H}_{2} \mathrm{O}$ (Sigma Aldrich). Esta massa foi adicionada na solução $A$, juntamente com uma segunda solução a base de hidróxido de sódio $(\mathrm{NaOH})$ na razão 3mol/L, sob agitação vigorosa. A solução resultante foi submetida a um tratamento hidrotermal a $80^{\circ} \mathrm{C}$ por $24,48,120$ e 168 horas. Após o tratamento hidrotermal o material foi lavagem com água deionizada, filtrado e seco a $50^{\circ} \mathrm{C}$.

O produto final foi caracterizado pelas técnicas de difração de raio $X$, espectroscopia de infravermelho obtido por um espectrômetro de absorção molecular na região de infravermelho com transformada de Fourier (FTIR) (Bruker, Vertex 70), utilizando uma pastilha prensada a vácuo contendo 0,200 g de $\mathrm{KBr}$ e 0,0013 g de amostra e por microscopia eletrônica de varredura (MEV-EDS) da marca LEOZeiss, $430 \mathrm{Vp}$, em condições de análise utilizando imagens secundárias obtidas a $20 \mathrm{kV}$, com distância de trabalho de $11 \mathrm{~mm}$, para reconhecimento da morfologia e análise semi-qualitativa do produto sintético final.

\section{I RESULTADOS E DISCUSSÕES}

\subsection{Resíduo de lavagem de bauxita}

A composição mineralofica realizada por difração de Raio $\mathrm{X}$ indentificou que o resíduo de lavagem de bauxita (RBAUX) é compostos principalmente por kaolinita, hematita, gibbsite, anatásio e quartzo (Costa et al.,2014). (Figura 1). Esta composição foi a mesma do seu produto comercial (bauxita lavada), o que sugere que o processo de beneficiamento de lavagem da bauxita, para separação e redução da granulometria da mesma, não afeta a mineralogia dos rejeitos.

A composição química, investigada por fluorescência de raios- $X$, (Tabela 1), mostrou uma composição média principalmente de $\mathrm{Al}_{2} \mathrm{O}_{3}(29 \%), \mathrm{Fe}_{2} \mathrm{O}_{3}(27,5 \%)$, o que pode está relacionado aos minerais gibbsita e hematita, respectivamente. Teores de $\mathrm{SiO}_{2}(24,6 \%)$ e $\mathrm{TiO}_{2}(3,9 \%)$ também foram detectados e foram atribuído às fases de caulinita, quartzo e anatásio. Estes resultados indicaram que o RBAUX é favorável à síntese de katoita. 


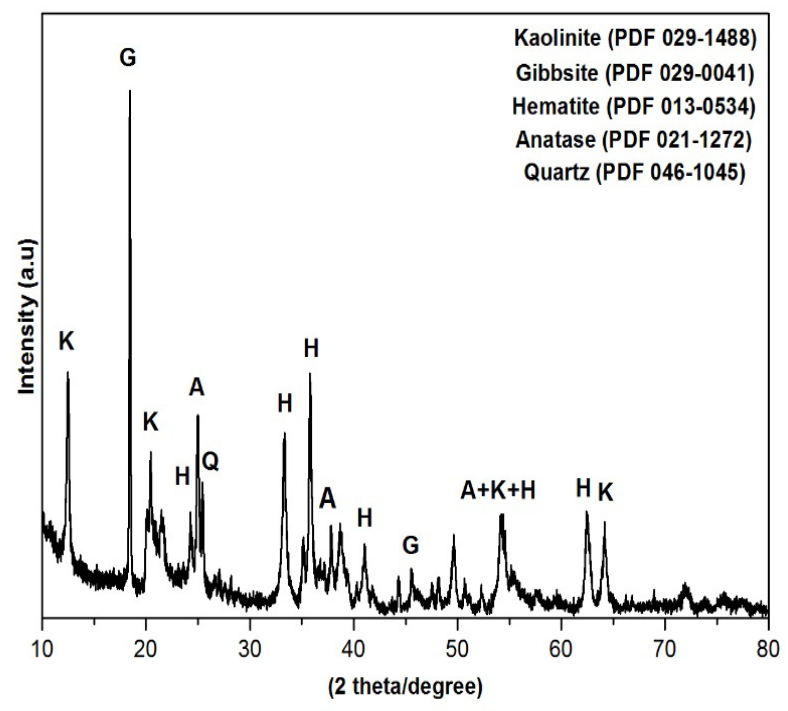

Figura 1. Padrão de DRX da amostra de rejeito de lavagem de bauxita, RBAUX.

\begin{tabular}{|c|c|c|c|c|c|c|c|}
\hline \multirow{2}{*}{ RBAUX } & $\mathrm{Al}_{2} \mathrm{O}_{3}(\%)$ & $\mathrm{Fe}_{2} \mathrm{O}_{3}(\%)$ & $\mathrm{SiO}_{2}(\%)$ & $\mathrm{TiO}_{2}(\%)$ & $\mathrm{ZrO}_{2}(\%)$ & $\mathrm{P}_{2} \mathrm{O}_{5}(\%)$ & P.F. (\%) \\
\cline { 2 - 8 } & 29,0 & 27,5 & 24,6 & 3,9 & 0,1 & $<0,1$ & 14,73 \\
\hline
\end{tabular}

Tabela 1. Composição química da RBAUX.

P.F. $=$ Perda ao fogo

\subsection{Transformação do rejeito em katoita}

A influência do tempo de cristalização na síntese de katoita foi analisada por DRX (Figura 2). Observou-se nos padrões de DRX a formação da katoita em todos os intervalos de tempo analisados devido a presença dos picos indexados em 17.28 ; 19.58; 26.52; 28.42; 31.87; 35.00; 39.28; 44.46; 52.54 e $54.67\left(2^{\circ} \theta\right)$ que correspondem aos planos cristalográficos (211), (220), (321), (400), (420), (422), (521), (532), (640) e (642). O sistema cristalino cubico, sendo $a=b=c=12.55 \AA$, grupo espacial la-3d e $V=1978,34 \AA^{3}$ (PDF 00-024-0217) (Olijnyk et al., 1991; Passaglia e Rinaldi, 1984). Além da formação da katoita, notou-se a formação de fases segundárias como calcita (PDF 00-047-1743), amostras obtidas após 120 e 168h, e hidrocalumita (PDF 00-042-0558), amostra obtida após 24h, devido a presença de seus picos principais em $2^{\circ} \theta=29,37$ e 11.18, respectivamente.

Conforme pôde ser observado a amostra obtida em $48 \mathrm{~h}$, a $80^{\circ} \mathrm{C}$, mostrou-se ideal para a obtenção da katoita pura, sem a ocorrência de fases segundárias (Figura 3). Segundo Passaglia \& Rinaldi (1984), o aumento de intensidade na reflexão (220) pode indicar que os ions $\mathrm{Fe}^{3+}$ estão em maior concentração nos octaédricos que formam a estrutura desse material, do que $\circ \mathrm{Al}^{3+}$. 


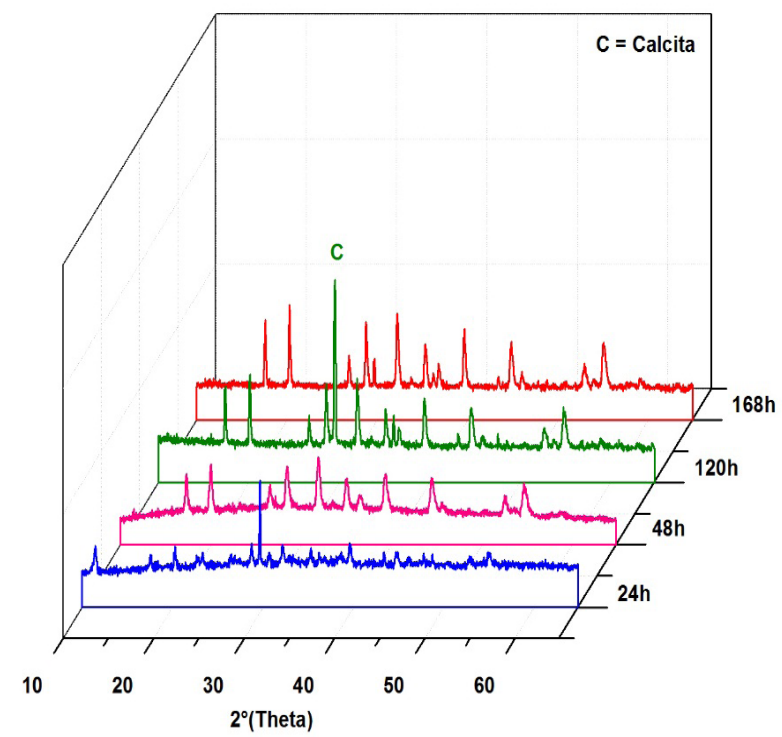

Figura 2. Padrões de DRX obtidos em 24, 48, 120 e 168 horas. $C$ = calcita.

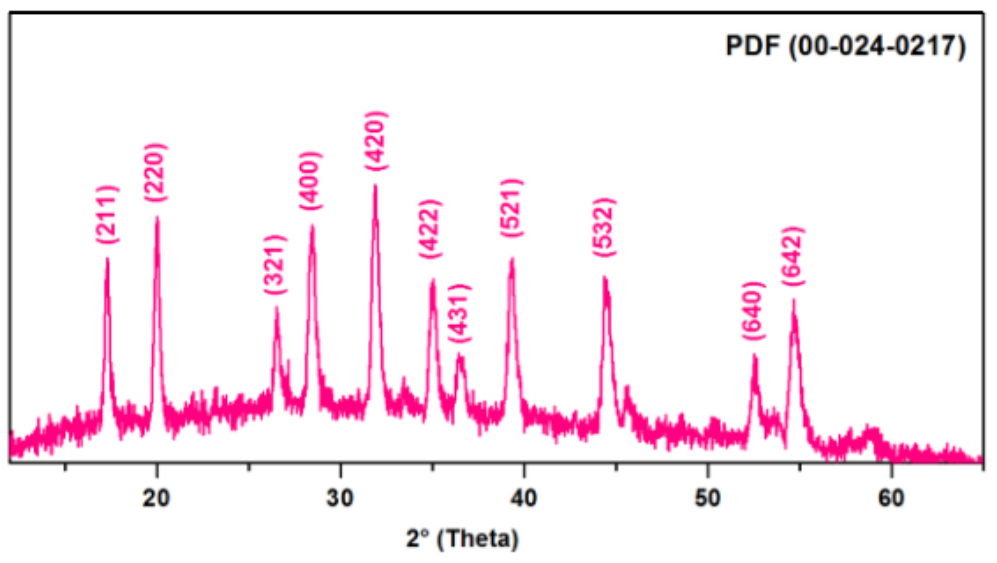

Figura 3. Padrões de DRX da katoita obtida após 48 horas.

Uma investigação por espectroscopia de infravermelho foi feita na amostra obtida após 48 horas (Figura 4). A banda em $3608 \mathrm{~cm}^{-1}$ corresponde as vibrações do estiramento $\mathrm{O}-\mathrm{H}$ de água livre ou quimicamente ligada a estrutura da katoita, enquanto as bandas em 1634 e $1469 \mathrm{~cm}^{-1}$ podem está relacionadas as vibrações do estiramento das bandas de $\mathrm{C}-\mathrm{O}$ do grupo do carbonato $\mathrm{CO}_{3}{ }^{2-}$ adsorvido na superfície do material. As bandas registradas em 876 e $454 \mathrm{~cm}^{-1}$ foram atribuídas as vibrações do estiramento Metal-O (Ca-O, Al-O, Fe-O) (Yang et al., 2017; Geiger \& Rossman, 2018). 


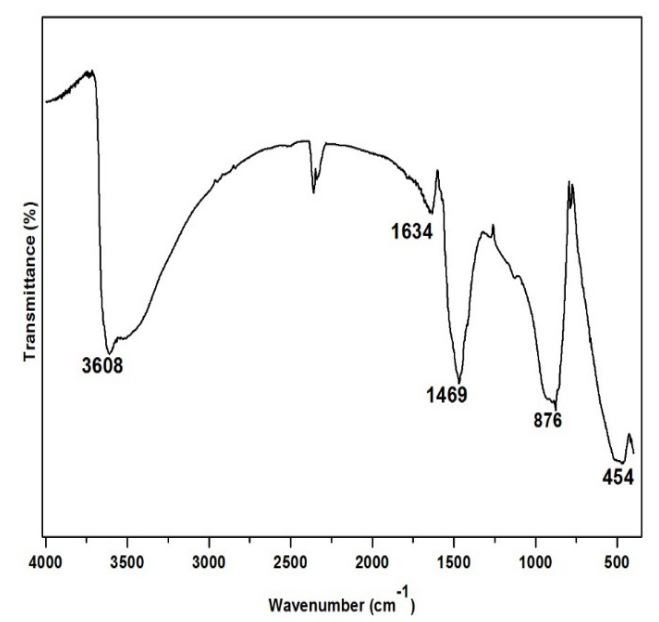

Figura 4. Espectro de infravermelho da katoita obtida a 48horas.

A morfologia da katoita por microscopia eletrônica de varredura (Figura 5), revelou um agregado de cristais octaédricos de $\mathrm{Ca} / \mathrm{Fe} / \mathrm{Al}$ com tamanho médio de $5 \mu \mathrm{m}$, cuja análise semi-quantitativa por EDS revelou uma composição média dos octaédricos de $\mathrm{Ca}=\sim 12.25, \mathrm{Fe}=\sim 6.75 \%$ e Al $=\sim 2.5 \%$ (Passaglia \& Rinaldi, 1984).

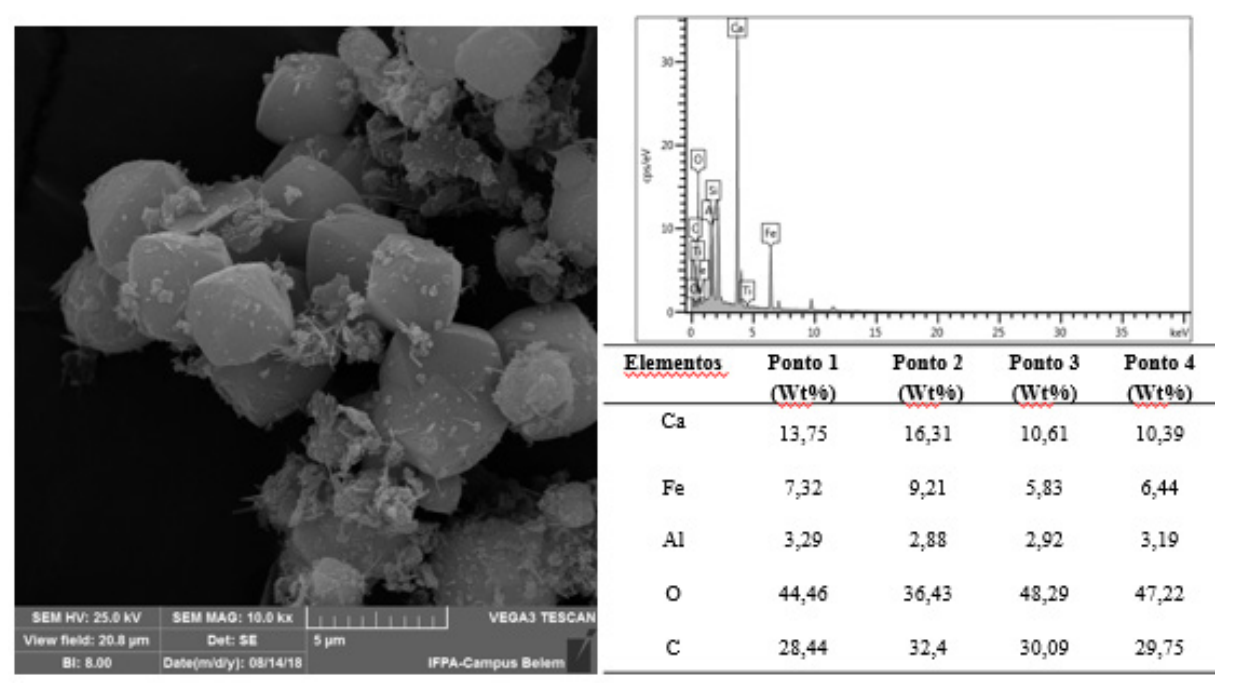

Figura 5. Morfologia do cristal de katoita por microscopia eletronica de varredura (MEV-EDS).

\section{I CONCLUSÃO}

Baseado nos resultados ilustrado neste trabalho, o resíduo de lavagem de bauxita da região Amazônica constituídos por kaolinita, gibbsita, hematita, anatásio e quartzo, com alto teor de $\mathrm{AL}_{2} \mathrm{O}_{3}$ e $\mathrm{Fe}_{2} \mathrm{O}_{3}$ mostrou-se ser uma excelente material de partida para a produção de hidrogrossular com estrutura análoga a katoita. A banda de infravermelho em $3608 \mathrm{~cm}-1$ é de fundamental importância para a confirmação da presença do grupo hidróxila $(\mathrm{OH})$ na estrutura cristalina do material, e o EDS 
releva uma composição de Ca-Fe/Al.

\section{AGRADECIMENTOS}

Os autores agradecem o apoio financeiro das agências de fomento CNPq (Universal 420169/2016-4), CAPES (88881.160695/2017-01) e IFPA-Campus Parauapebas (PA) pelo apoio institucional.

\section{REFERÊNCIAS}

ATKINS, M., AND GLASSER, F.P. Application of portland cement-based materials to radioactive waste immobilization. Waste Management, 12, 105-131. 1992.

COSTA, M, L. et al. On the geology, mineralogy and geochemistry of the bauxite-bearing regolith in the lower Amazon basin: Evidence of genetic relationships. Journal of Geochemical Exploration. 2014

DILNESA, B. Z. LOTHENBACH, B. RENAUDIN, G. WICHSER, A. KULIK, D. Synthesis and characterization of hydrogarnet $\mathrm{Ca}_{3}\left(\mathrm{Al}_{\mathrm{x}} \mathrm{Fe}_{1-\mathrm{x}}\right)_{2}\left(\mathrm{SiO}_{4}\right)_{\mathrm{y}}(\mathrm{OH})_{4}(3-\mathrm{y})$. Cement and Concrete Research, n. 59, pp. 96-111. 2014.

GEIGER. C.A; ROSSMAN. G.R. IR spectroscopy and OH - in silicate garnet: The long quest to document the hydrogarnet substitution. American Mineralogist, Vol 103, pp 384-393, 2018.

HILLIER, S., LUMSDON, D.G., BRYDSON, R., AND PATERSON, E. Hydrogarnet: A host phase for $\mathrm{Cr}(\mathrm{VI})$ in chromite ore processing residue (COPR) and other high pH wastes. Environmental Science and Technology, 41, 1921-1927. 2007.

KLEIN C. \& DUTROW B. Manual de ciência dos minerais. Traduzido por Rualdo Menegat. Porto Alegre: Bookman, Ed 23ª. pp. 724. 2012.

LACIVITA, V. MAHMOUD, A. ERBA, A. D. ARCO, F. MUSTAPHA, s. Hydrogrossular, Ca3AI2(SiO4)3$\mathbf{x}(\mathrm{H} 404) \mathbf{x}$ : An Ab initio investigation of its structural and energetic properties. 2015.

OLIJNYK, H. PARIS, E. GEIGER. C. A. G. A. LAGER. Compressional Study of Katoite [Ca3A12(O4H4)3] and Grossular Garnet. Journal of geophysical research, vol. 96, n. 14, pp.313-14. 1991.

PASSAGLIA, E. RINALDI, R. Katoite, a new member of the Ca3AI2(SiO4)3-Ca3AI2(OH)12 series and a new nomenclature for the hydrogrossular group of minerals. In: Bulletin de Minéralogie, vol. 107, n. 5, pp. 605-618. 1984.

SCHOENITZ, M. NAVROTSKY, A. Enthalpy of formation of katoite Ca3AI2[(OH)4]3: Energetics of the hydrogarnet substitution. American Mineralogist, Vol. 84, pp. 389-391. 1999.

YANG, J. LI, D. FANG, Y. Synthesis of Nanoscale CaO-Al2O3-SiO2-H2O and Na2O-Al2O3-SiO2H2O Using the Hydrothermal Method and Their Characterization. Materials (Basel), n.10, vol. 7, pp. 695. 2017. 


\section{AVALIAÇÃO DAS PROPRIEDADES DO CONCRETO ATRAVÉS DA ADIÇÃO DE FIBRAS DO COCO BABAÇU}

Data de aceite: 05/06/2020

Márcio do Nascimento Silva Graduando em Engenharia Civil Centro Universitário UniFACID-Wyden Engenharia, Teresina-PI marcio410@hotmail.com

Deuzuíta dos Santos Freitas Viana Licenciatura Plena em Ciências Biológicas

Engenharia Agronômica

Centro Universitário UniFACID-Wyden

Engenharia, Teresina-PI

deuzuitasfv@gmail.com

Lívia Racquel de Macêdo Reis

Engenharia Civil

Centro Universitário UniFACID-Wyden

Engenharia, Teresina-PI

liviareis@gmail.com

Wendel Melo Prudêncio de Araújo

Engenharia Civil

Centro Universitário UniFACID-Wyden

Engenharia, Teresina-PI

wendelprudencio@hotmail.com

RESUMO: A aplicação do Concreto Reforçado com Fibras, visando melhorar alguns aspectos de resistência à tração, tem despertado interesse na utilização de compósitos que asseguram ao concreto um maior controle de fissura. Assim, em uma sociedade cada vez mais atenta as questões ambientais, a utilização de materiais naturais indica uma saída sustentável. As fibras naturais apresentam benefícios por ser um material renovável e em larga escala, possuindo dessa forma, uma efetivação de baixo custo. Uma dessas fibras que estão presentes em grande quantidade, é do coco babaçu. Não obstante, este trabalho apresenta como objetivo avaliar as propriedades do concreto através da adição de fibras do coco babaçu. Dessa forma, esse trabalho é uma revisão de literatura em que há a adição de fibras do coco babaçu, na qual, baseia-se na sustentabilidade, visto que, esse material pode ser uma alternativa para a construção civil. À utilização das fibras de coco pode colaborar para o aumento da resistência do concreto, além de contribuir significativamente para o setor, levando-se em consideração diversos impactos e contenção de recursos não renováveis.

PALAVRAS-CHAVE: Concreto; Coco babaçu; Fibras; Resistência.

ABSTRACT: The application of Fiber Reinforced Concrete, in order to improve some aspects of tensile strength, has aroused interest in the use of composites that ensure concrete a greater crack control. Thus, in a society 
increasingly aware of environmental issues, the use of natural materials indicates a sustainable way out. Natural fibers have benefits for being a renewable and large-scale material, thus having a low cost effectiveness. One of these fibers that are present in large quantities, is the babassu coconut. Nevertheless, this work aims to evaluate the properties of concrete through the addition of babassu coconut fibers. Thus, this work is a literature review in which there is the addition of babassu coconut fibers, in which, it is based on sustainability, since this material can be an alternative for civil construction. The use of coconut fibers can contribute to increasing the strength of concrete, in addition to contributing significantly to the sector, taking into account various impacts and containment of non-renewable resources.

KEYWORDS: Concrete; Babassu coconut; Fibers; Resistance.

\section{I INTRODUÇÃO}

O setor da construção civil é importante nos aspectos econômicos e sociais, o que se apresenta em todas as peculiaridades de sua cadeia produtiva. Discussões a respeito dos aspectos ambientais tem ganhado cada vez mais força na sociedade atual, acredita-se que o futuro da humanidade depende principalmente da ação do homem.

Há alguns anos tem sido crescente o desenvolvimento de compósitos reforçados por fibras vegetais, assim, sendo uma alternativa viável para o meio ambiente e reduzindo o impacto ambiental. $O$ uso de fibras vegetais em materiais de construção tende a corroborar para diminuição da extração dos recursos não renováveis necessários para a produção de alguns compósitos cimentícios.

O Brasil é um dos países que apresenta uma grande variedade de biomassa, e uma extensão cultivável, sendo que esses potenciais podem serem explorados significativamente.

O Nordeste tem uma abundância em fibras naturais, dentre essas elas destacam-se o Buriti (Mauritia Flexuosa), o Babaçu (Orbignya Phalerata), a Carnaúba (Copernicia Prunífera), a Mamona (Ricinus Communis) e o Tucum (Astrocaryum Vulgare) (FRANCO, 2010). O uso desses recursos é restrito, sendo usuais nos afazeres domésticos, biodiesel, óleo, fonte de energia e de uso artesanal.

As fibras podem ser utilizadas na indústria, em processos de fabricação de produtos destinados a comercialização, assim apresentando elementos positivos por serem renováveis e biodegradáveis.

A adição de fibras nas matrizes pode melhorar as suas propriedades mecânicas, como a resistência à tração, à flexão e ao impacto. Além disso, altera seu comportamento após fissuração diminuindo os efeitos de uma ruptura brusca da matriz cimentícia (AGOPYAN \& SAVASTANO JUNIOR, 2007). 
Os compósitos no ramo da engenharia originam-se da combinação de dois ou mais elementos diferentes, podendo obter um material na qual suas propriedades são superiores, podendo ser até melhor em alguns aspectos. Para a utilização das fibras, é necessário conhecer suas propriedades, dessa forma, é fundamental o uso de técnicas, e a partir de então, desenvolver métodos de utilização e processamento de novos materiais, com base em fibras vegetais.

\section{I REFERENCIAL TEÓRICO}

\subsection{Babaçu}

O Babaçu (Orbignya Phalerata) é uma palmeira robusta, com tronco simples, chegando até a uma altura de 20 metros. Ela produz frutos de coloração marrom, o babaçu compõe-se de um cacho com número de cocos entre 150 a 250, apresentando em média de quatro cachos em uma palmeira, sendo uma palmeira do tipo mono caule.

O Brasil possui vastos babaçuais espalhados na região sul da bacia amazônica, na qual a floresta úmida cede lugar para a vegetação típica do cerrado. As maiores concentrações de babaçuais estão nos estados do Maranhão, Piauí e Tocantins constituídas de agrupamentos densos e homogêneos, além desses estados, destacam-se também Goiás, Minas Gerais e Espírito Santo com babaçuais de Orbignya spp.

A região compreendida entre Maranhã, Piauí e Tocantins é considerada a de maior concentração de plantas oleaginosas do mundo e fonte da maior produção extrativista vegetal (FRANCO, 2010).

No Piauí o babaçu está presente na região do baixo Parnaíba, incluindo cerca de 33 municípios, nas quais os maiores produtores são: Teresina, União, Palmeirais, Barras, Miguel Alves, Luzilândia, Matias Olímpio e Esperantina. O coco babaçu cai de maneira espontânea da palmeira, após a sua maturação, o coco é composto por Epicarpo, Mesocarpo, Endocarpo e Amêndoa. O epicarpo corresponde a $11 \%$ do peso do fruto, ele pode ser utilizado na produção de biocombustível e na queima direta em caldeiras. O mesocarpo é a massa que fica entre o epicarpo e o endocarpo, tem utilização na farinha, biocombustível e ainda em rações. $O$ endocarpo corresponde a $59 \%$ do peso do fruto, ele é utilizado na produção de carvão em várias regiões do Nordeste. A amêndoa constitui $7 \%$ do peso do fruto, serve de produção de óleo, permitindo o uso em cosméticos e domésticos. A casca que é $93 \%$ do fruto geralmente é desperdiçada no processo da quebra manual. 


\subsection{Fibras}

As fibras possuem uma geometria mais ou menos uniforme, com diâmetro minúsculo, com natureza diferenciada, possuindo diferentes propriedades físicoquímico. O uso de fibras como matéria prima apresenta vantagens em suas propriedades, tais como resistência a temperatura, densidade, baixo custo, resistência mecânica e disponibilidade no meio ambiente.

As fibras classificam-se em naturais, como origem vegetal, animal ou mineral e as fibras feitas pelo homem, o polímero natural e polímero sintético. As fibras vegetais tem classificação de acordo com sua origem, tais como fibras de sementes, fibras de caule, de folha, frutos e raízes. Essas fibras possuem aspectos vantajosos para o seu uso em virtude de baixo custo e de fácil renovação, altas propriedades específicas, origem natural abundante, baixa densidade, e contribuem para a diminuição do efeito estufa.

Quando essas fibras são adicionadas em algum polímero, os processos podem ser realizados por métodos convencionais em plásticos, como extrusão, injeção, prensagem e calandragem. As fibras podem serem incorporadas em uma matriz como reforço em suas diferentes formas, longa, curta, etc.

O concreto reforçado com fibras naturais é mais vulnerável que outros CRFs em termos de durabilidade. Os vazios altamente alcalinos presentes no concreto parecem deteriorar as fibras. (RIBEIRO e QUINTANILHA, 2016).

A durabilidade pode ter melhora com a alteração em cerca de $50 \%$ do cimento por sílica ativa, já que ela reage com a cal, assim reduzindo a alcalinidade dos vazios. A melhora da durabilidade pode ser alcançada através do revestimento da fibra com químicos apropriados como ácido fórmico e ácido esteárico $(\mathrm{ACl}, 2002$ et al, 2016).

As fibras vegetais manifestam variações dimensionais, isso ocorre divido apresentar mudanças no teor de umidade maiores que as presentes nas matrizes do cimento.

A absorção da água por fibras é elevada, sendo destaque principalmente as fibras de coco, quando ela é empregada seca, ela tende a puxar para si a água da hidratação do cimento, assim ocasionando uma deficiência na aderência de fibramatriz, e dessa forma, o cimento terá uma cura incompleta nesse aspecto.

Dessa maneira, a viabilidade técnica na utilização das fibras vegetais como reforço no concreto analisada pelos estudiosos, esse tipo de material é considerado alternativa para a modificação das fibras artificiais no compósito.

\subsection{Concreto Reforçado Com Fibras}

O concreto que contém fibras é denominado de concreto reforçado com 
fibras (CRF), ele pode conter além do cimento, agregados, água e fibras e outros adicionados usados geralmente no concreto convencional.

O concreto simples possui algumas limitações quanto ao seu comportamento frágil. Em virtude disso e devido a constante ação de cargas externas (tração), as diferenças de temperatura, umidade do meio ambiente e principalmente o efeito de retração hidráulica, que geralmente apresenta microfissuras no meio da matriz e os agregados graúdos, o que necessariamente pouca energia ocasiona o aumento destas fissuras.

No interior do concreto, tensões originadas pelos esforços sobre a estrutura, se propagam e de acordo com Figueiredo (2000), quando o concreto simples apresenta uma fissura, a mesma irá representar uma barreira à propagação dessas tensões.

Nesse momento, a tensão que anteriormente cruzava aquele segmento contornará seu percurso para outra região que permita a sua propagação, ou melhor, passam a se concentrar na extremidade da fissura provocando um crescimento incontrolado da mesma, onde, no momento em que esta força mecânica vence a resistência da matriz, ocorrerá o rompimento abrupto do material (BARROS, 2009, p. 48).

De acordo com FIGUEIREDO (2011) uma vantagem do CRF frente ao concreto armado: como a adição da fibra ocorre como as demais matérias-primas, há uma facilitação de aplicação do material, eliminando a necessidade de instalação da armadura convencional.

O principal efeito da adição de fibras misturado no concreto corresponde a diminuição do caráter frágil do material devido aumento da resistência a tração e como consequência o incremento do escoamento antes do colapso do concreto. Dessa maneira, o aumento da possibilidade de deformação implica na maior ductilidade do compósito com fibras se comparado ao concreto convencional, visto que está relacionado à segurança que a ruptura frágil é súbita enquanto a ruptura dúctil é paulatina.

Não existe um método específico para dosagem das fibras, mas no aspecto da resistência e tenacidade do concreto, é convencional ter uma concentração maior de fibras no concreto. FIGUEIREDO (2011) explica que a alteração da trabalhabilidade ocorre principalmente porque, ao adicionar a fibra ao concreto, está sendo adicionando também uma grande área superficial que demanda água de molhagem, de modo que uma menor quantidade de água estará disponível para fluidificar a mistura.

Assim, quanto menor o diâmetro da fibra, a influência da mesa tende a ser maior para a perda da fluidez da mistura, em outro aspecto, as fibras são agentes que combatem a segregação, visto que atuam para impedir a separação do agregado graúdo na mistura, dessa forma mantendo o compósito coeso. 


\subsection{Fibras De Coco Babaçu No Concreto}

A resistência à compressão geralmente é determinada aos 3, 7, 21 e 28 dias para todos os tipos de concretos obtidos. Dessa forma, a inclusão de fibras de coco babaçu nesse aspecto não apresentou resistência final quando a compressão. Tal resultado, é similar ao encontrado na literatura técnica, que afirma que a adição de fibras ao concreto não gera grandes aumentos de resistência à compressão, a exemplo dos resultados obtidos por BONATO et al (2011).

Os traços com teores maiores de fibras de coco babaçu tiveram desvantagens pela adição do mesmo, assim estando abaixo da exigência que é de $25 \mathrm{Mpa}$. Os vazios aprisionados pela inserção desses teores de fibras foram responsáveis pela dificuldade e transferir esforços de maneira homogênea, culminando em rupturas abruptas (RIBEIRO, QUINTANILHA, 2016).

No que tange a resistência à tração do concreto elas são capazes de "amarrar" as fissuras internas e retardar a ruptura, já que as fibras agem como elo de transferência de tensões. Assim, adição de fibras vegetais secas ao concreto está associada à perda de trabalhabilidade proporcional à quantidade de fibras inseridas. Portanto, para baixos teores de adição de fibras de coco babaçu, o CRF supera resistência à tração em comparação com concreto convencional.

\section{I CONCLUSÃo}

O uso de fibra vegetal para o setor da construção civil é de extrema relevância, pelo fato das propriedades mecânica e da durabilidade conduzirem a sua aplicação.

Diante do estudo, a caracterização dos compósitos reforçados com fibra de coco babaçu requer ainda estudos e análises mais aprofundadas, mesmo diante dos resultados apresentados, há possibilidade de aproveitamento dessas fibras na mistura na fabricação de concreto, embora apresente resultados satisfatórios quanto a durabilidade, resistência a compressão e a tração. Assim, deve-se levar em consideração a vida útil de degradação, com ênfase econômica na avaliação das potencialidades, assim podendo proporcionar a substituição de fibras industrializadas por fibras vegetais.

Vale destacar a importância da utilização de fibras de coco babaçu como alternativa socialmente responsável e ecológica, podendo proporcionar uma alteração significativa no custo da construção civil. A aplicação das fibras vegetais na indústria civil pode elencar geração de renda e emprego na confecção e produção de fibras destinadas à fabricação de compósitos, assim ajudando na socialização do indivíduo e na melhoria dos materiais para o setor da construção civil. 


\section{REFERÊNCIAS}

AGOPYAN, V; SAVASTANO JUNIOR, H. Fibras vegetais como materiais de construção. In: ISAIA, G. C. (editor) Materiais de construção civil e princípios de ciência e engenharia de materiais. São Paulo: Ibracon, 2007. 2v. 1721 p.

AMERICAN CONCRETE INSTITUTE. Design considerations for steel fiber reinforced concrete (ACI 544-4R-88). In: Manual of concrete practice. Detroit, Michigan, v.85, 1988.

AMERICAN CONCRETE INSTITUTE. NBR 15530: Fibras de aço para concreto. Especificação. Rio de Janeiro, 2007.

FIGUEIREDO, A. D. Concreto Reforçado com Fibras. Tese (Livre Docência), 256p. São Paulo/SP, 2011.

FRANCO, F. J. P. Coco Babaçu em Compósito com Matriz de Epóxi: Estudo do Efeito do Tratamento da Fibra. 2010. 77 p. Dissertação (Mestrado em Ciência e Engenharia de Materiais) Programa de Pós-Graduação em Ciências e Engenharia de Materiais da Universidade Federal do Rio Grande do Norte. Natal, 2010.

RIBEIRO, F. H. de M.; Avaliação das Propriedades Mecânicas de Concretos Reforçados com Fibras do Coco Babaçu. Belo Horizonte: Ibracon, 2016.

SAVASTANO JÚNIOR, H.; PIMENTEL, L. L. Viabilidade do aproveitamento de resíduos de Fibras vegetais para fins de obtenção de material de construção. Revista Brasileira de Engenharia Agrícola Ambiental, v.4, p.103-110, 2000. 


\section{COMPARAÇÃO DA RESISTÊNCIA À COMPRESSÃO AXIAL DE CONCRETOS DE ALTA RESISTÊNCIA (CAR) COM INSERÇÃO DE NANOTUBOS DE CARBONO (NTC) E CINZAS DE CASCA DE ARROZ (CCA)}

Data de aceite: 05/06/2020

Christa Korzenowski Universidade Estadual do Rio Grande do SulUERGS ckorzenowski@gmail.com

Rosangel Rojas Aguero rosangelrojasa@hotmail.com Ronaldo Beraldin da Silva ronaldoberaldin@hotmail.com;

Priscila Marques Correa priengenheira@gmail.com Luiz Carlos Pinto Silva Filho Icarlos66@gmail.com

RESUMO: O uso de adições minerais no concreto vem se difundindo cada vez mais por meio de estudos que visam diversas características, como: aumento da durabilidade, aumento da resistência mecânica e reaproveitamento de resíduos. Esta pesquisa comparou a resistência à compressão axial obtida de concretos contendo adições minerais (escória de alto forno e sílica fume) e cinza de casca de arroz com concretos contendo adições minerais e nanotubos de carbono. Além disso as misturas eram compostas cimento Portland CPV ARI, areia fina (areia de sílica), aditivo superplastificante e água. Foram realizados ensaios de caracterização dos materiais utilizados e as comparações entre os traços foram feitas a partir do ensaio de compressão axial de corpos de prova cilíndricos. Através dos resultados encontrados constatou-se que aos 28 dias todas as misturas com CCA apresentam valores de resistência à compressão de 2,5 a $68,5 \%$ maiores que com NTC. Mesmo aos 90 dias, três das misturas apresentaram melhores resultados com CCA; em termos econômicos, a mistura contendo cinza de casca de arroz é mais viável. Pelos resultados de compressão obtidos observou-se que a melhor mistura foi a que continha $55 \%$ de cimento e $20 \%$ de CCA.

PALAVRAS-CHAVE: Nanotubos de carbono, Cinzas de casca de arroz, Cimento Portland, Resistência à compressão axial.

COMPARISON OF AXIAL COMPRESSIVE STRENGTH OF HIGH STRENGTH CONCRETE (HSC) WITH INSERTION OF CARBON NANOTUBES (NTC) AND RICE HUSK ASH (CCA).

ABSTRACT: The use of mineral additions in concrete has become increasingly widespread by means of studies that aim the most diverse 
characteristics, such as: increasing the durability, increasing the mechanical resistance and utilization of industrial waste. This research aims to compare axial resistance strength of concretes containing minerals additions (ground granulated blast-furnace slag) and rice husk ash with those containing minerals additions and carbon nanotubes. Mixtures were composed of Portland cement CPV ARI, fine sand, ground granulated blast-furnace slag, silica fume, superplasticizer, water and rice husk ash or carbon nanotubes. Assays were performed to characterize the materials used and comparisons were made between the traces from the axial compression test of cylindrical specimens. Results show that at 28 days all the mixtures with CCA have values of compressive strength of 2.5 to $68.5 \%$ higher than with NTC. Even at 90 days, three of the mixtures presented better results with CCA; in economic terms, the mixture containing rice husk ash is more feasible. From the obtained compression results it was observed that the best blend was that containing 55\% cement and 20\% CCA.

KEYWORDS: Carbon Nanotubes, Portland cement, axial compressive strenght.

\section{I INTRODUÇÃO}

O concreto é um material utilizado em larga escala no mundo inteiro. Em sua fase final de aplicação, após algumas horas, apresenta-se de forma sólida, passando a ideia de ser um produto altamente resistente, denso, indestrutível, durável, fácil de ser produzido. Possui muitas de possibilidades de utilização, visando a melhoria e o bem estar da sociedade, facilitando os deslocamentos, melhoria do habitat, aplicações na indústria e várias outras. Em sua forma final apresentase em estruturas, revestido ou aparente. Dependendo das condições climáticas e ambientais, o concreto estará sujeito aos efeitos de um conjunto de agentes agressivos e diferentes fatores destrutivos que podem ocorrer de forma isolada, tais como: mecânicos (impactos), físicos (lixiviação), químicos e biológicos. Devido às ações ambientais atuantes no concreto, que vai interagir com a microestrutura e as propriedades do concreto, podem ocasionar mudanças com o tempo. [1].

Cada vez mais há a necessidade de se ter concretos mais duráveis e resistentes, pois os custos de manutenção e reparação são extremamente altos. Nesse sentido, o uso de adições minerais como sílica fume, pó de quartzo, escória de alto forno e cinza de casca de arroz no concreto vem se difundindo cada vez mais por meio de estudos que visam as mais diversas características, como: aumento da durabilidade, aumento da resistência mecânica e aproveitamento de resíduos industriais. Assim, estudos sobre concreto com adições minerais também, estão ganhando espaço principalmente pelo aumento de resistência que proporcionam [2,3,4,5,6]. Em 1993, o American Concrete Institute - ACI [7] definiu o concreto de alta resistência como sendo aquele que atinge resistência à compressão maior ou 
igual a $41 \mathrm{MPa}$. Porém, essa definição pode variar em cada região, visto que em alguns locais já se comercializa concretos com resistência em torno de $60 \mathrm{MPa}$. Assim, para se chamar um concreto de concreto de alta resistência (CAR), sua resistência à compressão deve ficar entre 83 e 103 MPa [8]. Sua composição inclui cimento, aditivos minerais (por exemplo: cinza volante, sílica fume, escória de alto forno, pó de quartzo), areia de sílica, superplastificante e água, para formar uma densa matriz sem agregado graúdo com baixa porosidade e alta resistência. Esta resistência é alcançada principalmente pela alta quantidade de cimento na mistura, tornando-o um material de alto custo e impactante ao meio ambiente. O CAR tem um custo por $\mathrm{m}^{3}$ de quatro a cinco vezes maior que o concreto tradicional, usando como aglomerante apenas o cimento [9], mas esse custo pode ser reduzido se forem utilizados resíduos como a cinza de casca de arroz (CCA), sílica fume e escória de alto forno (GGBS). A obtenção de produtos cimentícios contendo cinza da casca de arroz também é uma alternativa para solucionar o problema da disposição das cinzas no meio ambiente, além de gerar um material de maior valor agregado. $O$ emprego da cinza da casca de arroz tende a promover melhorias nas propriedades mecânicas e na durabilidade de concretos, além de reduzir a temperatura de hidratação [3].

Estudos têm mostrado seu potencial para a utilização na construção civil, principalmente como material pozolânico. A eficácia da CCAcomo material pozolânico está ligada ao processo pelo qual passa a casca de arroz para a obtenção da cinza. O material oriundo da combustão não controlada geralmente não atinge grande valor pozolânico, pois sua composição apresenta minerais de sílica não reativos (cristalinos), que só passam a ter maior atividade pozolânica quando micronizados. Com o processo controlado de queima, entre 500 a $700^{\circ} \mathrm{C}$, o produto gerado é uma cinza amorfa de alta pozolanicidade. O teor de carbono afeta a coloração da CCA e, esta podendo variar entre as tonalidades mais escuras até as mais claras, que vão de preto/cinza a branco-roseado. Quanto mais escura, maior o teor de carbono, ou seja, maior a quantidade de matéria orgânica não queimada $[10,11]$

Da mesma forma que a CCA, os nanotubos de carbono (NTC) apresentam extraordinárias propriedades físicas e mecânicas e têm sido alvo de estudos em concretos. Mais especificamente, no que diz respeito aos materiais para a construção civil, os NTC têm sido recentemente estudados como reforço em materiais à base de cimento para melhorar condições mecânicas, aumentar a durabilidade e contribuir para desenvolver estruturas multifuncionais [12,13,14,15,16]. Como o LEME (Laboratório de Ensaios e Modelos Estruturais) da UFRGS detêm uma patente de fabricação de NTC a partir de resíduos (Patente sob o número BR 102012022053 9 A2), resolveu-se utilizá-los em misturas de concreto e comparar seu desempenho com misturas de concreto nos quais se utilizou cinzas de casca de arroz. 
Neste sentido, esta pesquisa desenvolveu concretos de alta resistência com adição de $1 \%$ de NTC e $10 \%$ de CCA.

\section{I MATERIAIS E MÉTODOS}

\subsection{Variáveis}

Para obtenção de HSC sabe-se pela literatura que deve-se diminuir a relação água cimento $(\mathrm{a} / \mathrm{c})$ e a relação água agregado $(\mathrm{a} / \mathrm{b})$ deve estar entre 0,15 e 0,20 por isso manteve-se esses cuidados na obtenção das proporções das misturas. Do ponto de vista sustentável observou-se como as proporções dos resíduos industriais utilizados na mistura afeteram a evolução da resistência à compressão dos corpos de prova com o tempo, cuja cura foi a temperatura ambiente.

\subsection{Materiais}

Os materiais aglomerantes utilizados para a realização desta pesquisa foram constituídos por:

- Cimento Nacional tipo Portland CPV ARI com alta resistência inicial;

- Escória de alto forno (GGBS), da qual se obteve o lote de material para os ensaios segundo a norma NBR NM 26;

- Sílica Fume ND SILMIX ;

- Nanotubos de Carbono (LEME-UFRGS);

- Cinza de casca de arroz SILCCA NOBRE SCI ;

A cinza de casca de arroz empregada é proveniente da região oeste do Estado do Rio Grande do Sul e processada no Município de Alegrete.

O material agregado utilizado foi areia de sílica com tamanho máximo de grão de 0,30 $\mu \mathrm{m}$. Como aditivo superplastificante foi utilizado o CQ FLOW 3780, a base de policarboxulato.

\subsection{Proporção de Materiais}

Os experimentos foram realizados com 12 diferentes traços, 6 traços com NTC e 6 traços com CCA, para uma comparação do efeito da adição de NTC e da CCA. Em 6 traços foi fixado a adição de NTC em 1\% em peso em relação a massa de cimento e em outros 6 traços foi fixado a adição entre 10 e 20\% de CCA. As dosagens estabelecidas podem ser observadas na Tabela 1 e Tabela 2. 


\begin{tabular}{c|c|c|c|c|c|c|c|c|c|c|c|c|c}
\hline MATERIAIS & \multicolumn{2}{|l}{ CAR 1 } & \multicolumn{2}{l}{ CAR 2 } & \multicolumn{2}{l|}{ CAR 3 } & \multicolumn{2}{l}{ CAR 4 } & \multicolumn{2}{l}{ CAR 5 } & \multicolumn{2}{l}{ CAR 6 } \\
\hline & $\mathrm{Kg} / \mathrm{m}^{3}$ & $\%$ & $\mathrm{Kg} / \mathrm{m}^{3}$ & $\%$ & $\mathrm{Kg} / \mathrm{m}^{3}$ & $\%$ & $\mathrm{Kg} / \mathrm{m}^{3}$ & $\%$ & $\mathrm{Kg} / \mathrm{m}^{3}$ & $\%$ & $\mathrm{Kg} / \mathrm{m}^{3}$ & $\%$ \\
\hline Cimento & 597 & 50 & 657 & 55 & 776,1 & 65 & 597 & 50 & 657 & 55 & 776,1 & 65 \\
\hline GGBS $600 \mu$ & 537,3 & 45 & 418 & 35 & 179,1 & 15 & ---- & --- & ---- & --- & ---- & ---- \\
\hline GGBS $1180 \mu$ & ---- & --- & ---- & --- & ---- & --- & 537,3 & 45 & 418 & 35 & 179,1 & 15 \\
\hline NTC & 5,97 & 1 & 6,57 & 1 & 7,76 & 1 & 5,97 & 1 & 6,57 & 1 & 5,97 & 1 \\
\hline $\begin{array}{c}\text { Sílica Fume } \\
\text { (SF) }\end{array}$ & 59,7 & 05 & 119 & 10 & 238,8 & 20 & 59,7 & 05 & 119 & 10 & 238,8 & 20 \\
\hline Areia & 1051 & -- & 1051 & -- & 1051 & -- & 1051 & -- & 1051 & -- & 1051 & -- \\
\hline SP & 40 & -- & 40 & -- & 40 & -- & 40 & -- & 40 & -- & 40 & -- \\
\hline Água & 185 & -- & 185 & -- & 185 & -- & 185 & -- & 185 & -- & 185 & -- \\
\hline
\end{tabular}

Tabela 1: Misturas para produção de HSC com Nanotubos de Carbono

\begin{tabular}{|c|c|c|c|c|c|c|c|c|c|c|c|c|}
\hline MATERIAIS & CAR & 7 & CAR & 8 & CAR & 9 & CAR & 10 & CAR & 11 & CAR 12 & \\
\hline & $\mathrm{Kg} / \mathrm{m}^{3}$ & $\%$ & $\mathrm{Kg} / \mathrm{m}^{3}$ & $\%$ & $\mathrm{Kg} / \mathrm{m}^{3}$ & $\%$ & $\mathrm{Kg} / \mathrm{m}^{3}$ & $\%$ & $\mathrm{Kg} / \mathrm{m}^{3}$ & $\%$ & $\mathrm{Kg} / \mathrm{m}^{3}$ & $\%$ \\
\hline Cimento & 597 & 50 & 657 & 55 & 776 & 65 & 597 & 50 & 597 & 50 & 896 & 75 \\
\hline GGBS $600 \mu$ & 299 & 25 & 179 & 15 & 60 & 5 & $-\cdots-$ & --- & $-\cdots--$ & -- & ---- & -- \\
\hline GGBS $1180 \mu$ & ----- & -- & ------ & --- & ------ & --- & 299 & 25 & 299 & 25 & ---- & -- \\
\hline $\mathrm{CCA}$ & 239 & 20 & 239 & 20 & 119 & 10 & 179 & 15 & 119 & 10 & 119 & 10 \\
\hline $\begin{array}{l}\text { Sílica Fume } \\
\text { (SF) }\end{array}$ & 60 & 5 & 119 & 10 & 239 & 20 & 119 & 10 & 179 & 15 & 179 & 15 \\
\hline Areia & 1051 & -- & 1051 & $\begin{array}{l}--- \\
---\end{array}$ & 1051 & --- & 1051 & $\begin{array}{l}--- \\
--\end{array}$ & 1051 & $\begin{array}{l}--- \\
--\end{array}$ & 1051 & --- \\
\hline SP & 40 & --- & 40 & -- & 40 & -- & 40 & $\begin{array}{l}--- \\
--\end{array}$ & 40 & $\begin{array}{l}--- \\
--\end{array}$ & 40 & -- \\
\hline Água & 185 & -- & 185 & --- & 185 & --- & 185 & --- & 185 & -- & 185 & -- \\
\hline
\end{tabular}

Tabela 2: Misturas para produção de HSC com Cinza de casca de arroz

\subsection{Moldagem dos Corpos de Prova}

As misturas foram moldadas em corpos de prova (cps) de $5 \times 10 \mathrm{~cm}$, de acordo com a NBR 5739 [13]; adotou-se a cura dos corpos de prova apenas em câmara úmida.

\subsection{Ensaios}

Foram realizados os seguintes ensaios para caracterizar os materiais utilizados:

- Microscopia Eletrônica de Varredura (MEV) ( NTC)

- Espectroscopia Ra

man (NTC)

- Difração de Raios-X (NTC e CCA)

- Granulometria Laser (CCA, GGBS, Cimento)

Para os corpos de prova com NTC, os testes de resistência à compressão 
axial foram realizados aos 14, 28,56 e 90 dias.

Para os corpos de prova com CCA os testes de resistência à compressão axial foram realizados aos 7,14 e 28 dias.

\subsection{Dados técnicos}

Os dados técnicos do cimento e do superplastificante foram fornecidos pelos seus respectivos fabricantes e encontram-se detalhados abaixo. A Figura 1 mostra as propriedades do cimento Portlandb CPV-ARI utilizado nos ensaios.

\begin{tabular}{|c|c|c|c|c|c|c|c|c|c|c|}
\hline & \multicolumn{10}{|c|}{ Químicos } \\
\hline & $\mathrm{Al}_{2} \mathrm{O}_{3}$ & $\mathrm{SiO}_{2}$ & $\mathrm{Fe}_{2} \mathrm{O}_{3}$ & $\mathrm{CaO}$ & $\mathrm{MgO}$ & $\mathrm{SO}_{3}$ & $\begin{array}{l}\text { P. } \\
\text { Fogo }\end{array}$ & $\mathrm{CaO} \mathrm{L}$. & $\begin{array}{l}\text { R. } \\
\text { Ins. }\end{array}$ & $\begin{array}{l}\text { Eq. } \\
\text { Alc. }\end{array}$ \\
\hline & $\%$ & $\%$ & $\%$ & $\%$ & $\%$ & $\%$ & $\%$ & $\%$ & $\%$ & $\%$ \\
\hline Média & 4,13 & 18,30 & 2,51 & 59,69 & 5,36 & 2,85 & 3,17 & 1,04 & 0,72 & 0,62 \\
\hline Sd & 0,02 & 0,04 & 0,03 & 0,03 & 0,07 & 0,05 & 0,16 & 0,26 & 0,09 & 0,02 \\
\hline Min & 4,09 & 18,25 & 2,46 & 59,64 & 5,24 & 2,77 & 2,93 & 0,81 & 0,58 & 0,60 \\
\hline \multirow[t]{8}{*}{ Max } & 4,15 & 18,38 & 2,54 & 59,73 & 5,46 & 2,94 & 3,46 & 1,65 & 0,86 & 0,68 \\
\hline & \multicolumn{10}{|c|}{ Físicos } \\
\hline & $\begin{array}{l}\text { Exp. } \\
\text { Quente }\end{array}$ & $\begin{array}{l}\text { Cons. } \\
\text { Normal }\end{array}$ & Blaine & $\# 200$ & $\begin{array}{c}\# \\
325\end{array}$ & \multicolumn{5}{|c|}{ Resistência à Compressão (MPa) } \\
\hline & $\mathrm{Mm}$ & $\%$ & $\mathrm{~cm}^{2} / \mathrm{g}$ & $\%$ & $\%$ & $\begin{array}{c}1 \\
\text { Dia }\end{array}$ & 3 Dias & 7 Dias & \multicolumn{2}{|c|}{28 Dias } \\
\hline & 0,45 & 27,6 & \begin{tabular}{|l|}
4.337 \\
\end{tabular} & 0,27 & 2,58 & 22,1 & 34,5 & 42,0 & \multicolumn{2}{|c|}{48,9} \\
\hline & 0,50 & 0,2 & 100,78 & 0,05 & 0,61 & 0,8 & 1,2 & 0,6 & \multicolumn{2}{|c|}{1,0} \\
\hline & 0,00 & 27,4 & 4.17 & 0,20 & 1,30 & 20,4 & 32,9 & 41,2 & \multicolumn{2}{|c|}{47,3} \\
\hline & 1,00 & 27,8 & 4.48 & 0,30 & 3,70 & 23,0 & 36,2 & 43,2 & \multicolumn{2}{|c|}{50,2} \\
\hline
\end{tabular}

Figura 1: Propriedades do cimento Portland CPV - ARI [16].

Fonte: Itambé (www.cimentoitambe.com.br)

Sabe-se que o CPV-ARI é um cimento de alta resistência inicial, possui alta reatividade em baixas idades em função do grau de moagem a que é submetido, proporcionando maior rendimento ao concreto.

A Tabela 3 mostra as propriedades do superplastificante CQ Flow 3780

\begin{tabular}{l|l}
\hline \multicolumn{2}{c}{ DADOS TÉCNICOS } \\
\hline Base Química & Éter carboxilato \\
\hline Aspecto & Líquido \\
\hline Cor & Castanho \\
\hline $\mathrm{pH}$ & 5,0 a 7,0 \\
\hline Densidade & $1,08-1,12 \mathrm{~g} / \mathrm{cm} 3$ \\
\hline
\end{tabular}

Tabela 3: Dados técnicos do superplastificante CQ FLOW 3780

Segundo o fabricante, o CQ Flow 3780 é um aditivo superplastificante de terceira geração a base de policarboxilato, pronto para consumo, totalmente isento 
de cloretos e compatível com diversos tipos de cimento. Foi desenvolvido para reduzir grande quantidade de água de amassamento, dependendo da aplicação e redução desejada, conferindo excelente trabalhabilidade sem alterar o tempo de pega.

\section{I CARACTERIZAÇÃO DOS MATERIAIS}

\subsection{Caracterização do Nanotubos de Carbono}

Para os Nanotubos de Carbono, verificou-se a obtenção destes através de Microscopia Eletrônica de Varredura (MEV) e Espectroscopia Raman e sua composição através de difração de raios-x.

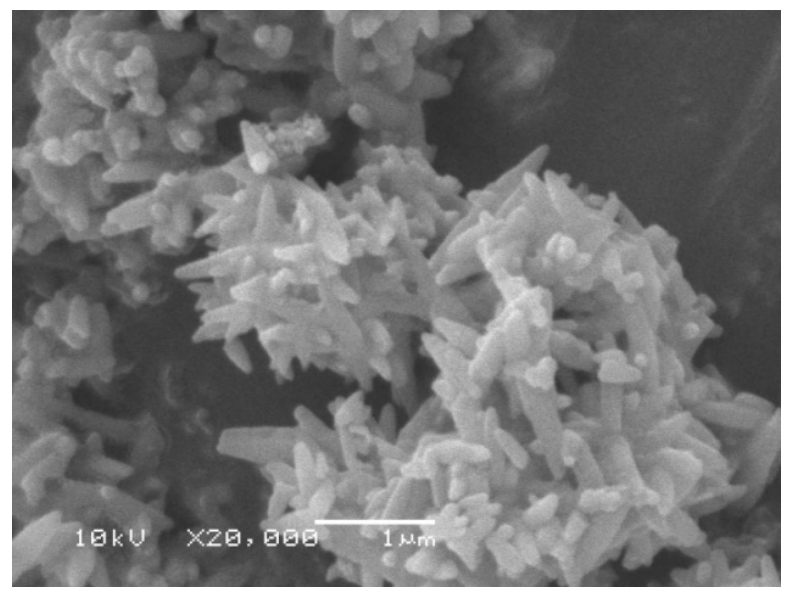

Figura 2: MEV dos Nanotubos de Carbono fabricados no LEME-UFRGS.

Pela análise da imagem de microscopia eletrônica de varredura é possível observar emaranhados de estruturas de tamanho nanométrico, que correspondem a nanotubos de carbono. Os NTC produzidos por esse método apresentam pouco comprimento como pode ser observado também na imagem. Para fins de comprovação de que o material produzido seria NTC, fez-se uma análise deste por Espectroscopia Raman, cujo espectro está mostrado na Figura 3. 


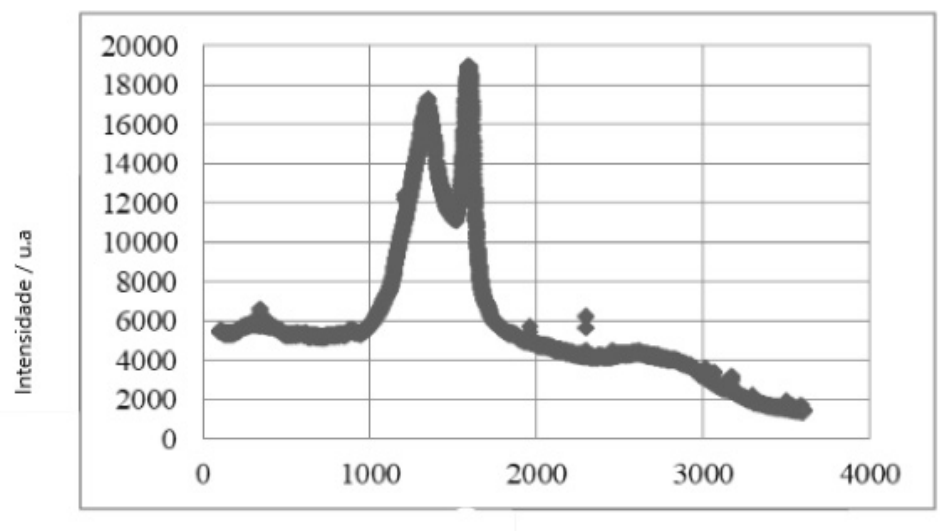

Deslocamento Raman (cm-1)

Figura 3 - Espectroscopia Raman dos NTC.

No espectrograma observa-se uma banda em torno de $1350 \mathrm{~cm}-1$ e outra em torno de $1575 \mathrm{~cm}-1$ que são características de NTC. A primeira banda, em torno de $1350 \mathrm{~cm}-1$ está associada à presença de estruturas desordenadas, como NTC defeituosos ou impurezas, e a segunda banda está associada a NTC perfeitos por isso quanto maior em relação a primeira banda, melhor. Como os NTC utilizados são fabricados a partir de resíduos, a banda em torno de $1350 \mathrm{~cm}-1$ é elevada pelas impurezas do material.A Figura 4 mostra a composição da mistura (NTC) produzida através da Difração de Raios-X.

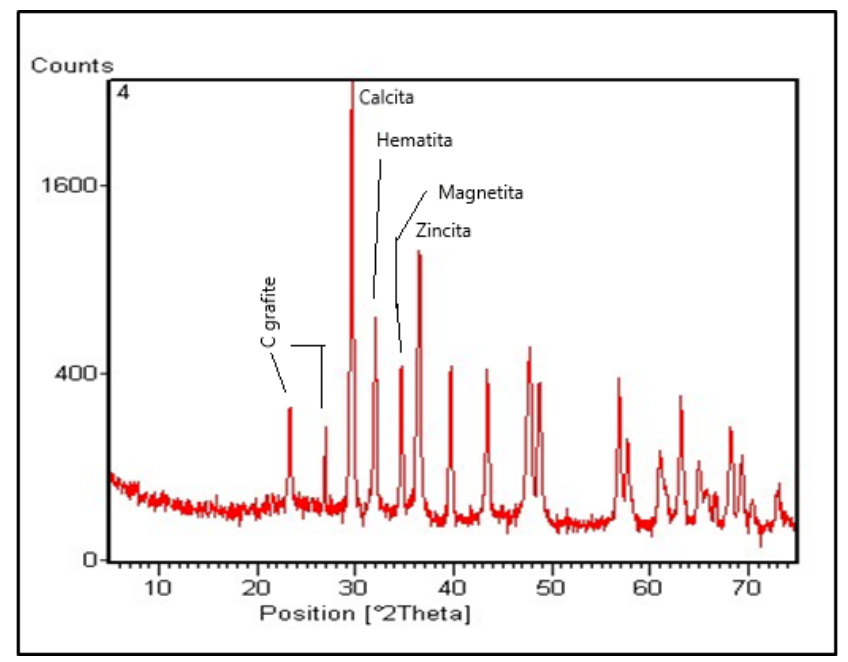

Figura 4: Difratograma dos NTC.

Pode-se notar dois picos nas posições 23 e 26,4 que são característicos do grafite, cujo NTC são uma forma alotrópica. Outros picos podem ser observados no espectro devido aos outros compostos químicos utilizados no preparo, como zinco e cálcio. 
A Figura 4 mostra uma imagem dos nanotubos de carbono fabricados no LEME.

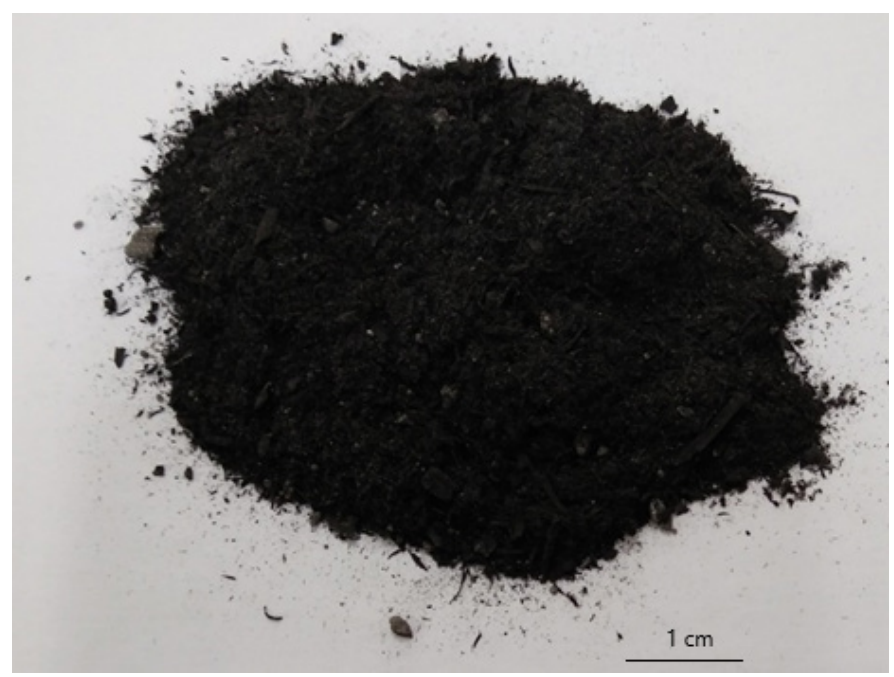

Figura 5: Imagem dos Nanotubos de Carbono fabricados no LEME.

\subsection{Caracterização da cinza de casca de arroz}

A cinza de casca de arroz utilizada nos ensaios não passou pelo processo de moagem, sendo utilizada como o fabricante fornece. Para caracterizar-se a cinza de casca de arroz foram determinadas as propriedades físico-químicas, a composição através de difração de raios- $x$, bem como a granulometria do material através do ensaio de granulometria a laser. As propriedades físico-químicas estão demonstradas na Tabela 3.

\begin{tabular}{l|l}
\hline Estado Físico & Sólido \\
\hline Diâmetro Médio & $<8,0 \mu \mathrm{m}$ \\
\hline $\begin{array}{l}\text { Resíduo na peneira de } \\
45 \mu \mathrm{m}\end{array}$ & $\leq 10,0 \%$ \\
\hline Aparência & Pó de dimensões micrométricas \\
\hline Cor & Cinza claro \\
\hline Odor & Sem odor \\
\hline pH & $\leq 10,0 \%$ \\
\hline Ponto de fusão & $1550-170^{\circ} \mathrm{C}$ \\
\hline Ponto de fulgor & Não aplicável \\
\hline Perda ao Fogo & $\leq 3,5 \%$ \\
\hline Densidade aparente & $550-560 \mathrm{~kg} / \mathrm{m}^{3}$ \\
\hline Solubilidade & $\begin{array}{l}\text { Insolúvel em água; solúvel em } \mathrm{HF} \\
\text { ou NaOH }\end{array}$ \\
\hline Área específica B.E.T & $20000 \mathrm{~m}^{2} / \mathrm{Kg}$ \\
\hline Limite de explosividade & Não aplicável \\
\hline
\end{tabular}

Tabela 4: Propriedades físico-químicas da cinza de casca de arroz.

A Tabela 5 mostra a composição da cinza de casca de arroz através da difração de raios- $x$. 


\begin{tabular}{l|l}
\hline ANALYTO & RESULTADO \% \\
\hline $\mathrm{SiO}_{2}$ & 95,3805 \\
\hline $\mathrm{K}_{2} \mathrm{O}$ & 1,8756 \\
\hline $\mathrm{CaO}$ & 1,0365 \\
\hline $\mathrm{P}_{2} \mathrm{O}_{5}$ & 0,5549 \\
\hline $\mathrm{MnO}$ & 0,3897 \\
\hline $\mathrm{SO}_{3}$ & 0,2540 \\
\hline $\mathrm{Al}_{2} \mathrm{O}_{3}$ & 0,2442 \\
\hline $\mathrm{Cl}$ & 0,1229 \\
\hline $\mathrm{MgO}$ & 0,1070 \\
\hline $\mathrm{NiO}$ & 0,0345 \\
\hline
\end{tabular}

Tabela 5: Composição química da cinza de casca de arroz

Pode-se observar que a maior parte do material ( $>90 \%$ ) é composto de óxido de silício $\left(\mathrm{SiO}_{2}\right)$, o que comprova os dados fornecidos pelo fabricante (Tabela 3 ) de que a obtenção da cinza é por queima controlada. A Figura 6 mostra uma imagem da CCA utilizada.

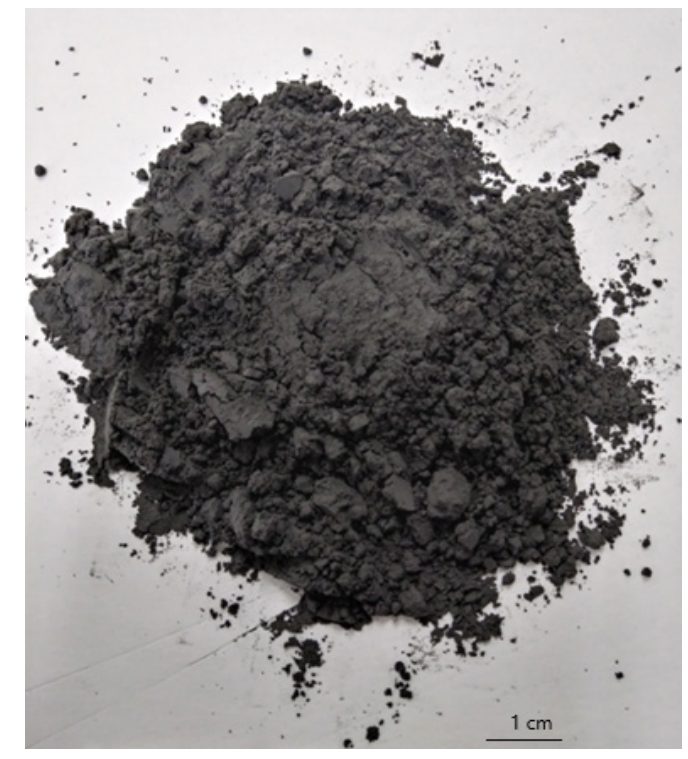

Figura 6: Imagem da cinza de casca de arroz.

A distribuição granulométrica da cinza de casca de arroz realizada através de granulometria a laser está mostrada na Figura 7. 


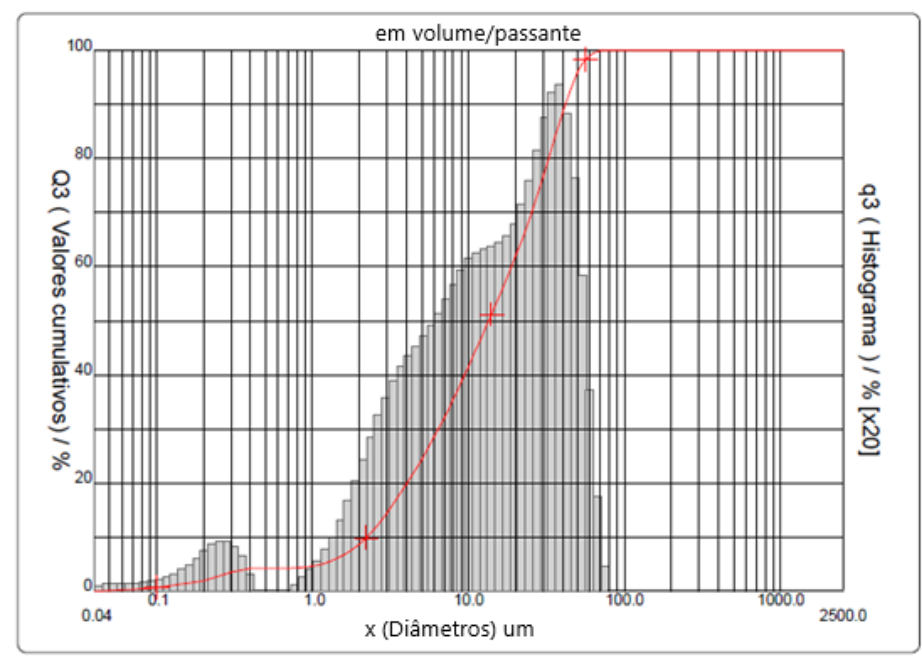

Figura 7: Distribuição granulométrica da cinza de casca de arroz e curva cumulativa.

Observa-se pela curva de distribuição granulométrica que a matéria-prima da cinza de casca de arroz apresenta uma faixa de distribuição granulométrica variando de 0,04 a $90 \mu \mathrm{m}$, com $\mathrm{D}_{10}$ de $2,22 \mu \mathrm{m}, \mathrm{D}_{50}$ de $13,43 \mu \mathrm{m}, \mathrm{D}_{90}$ de $41,72 \mu \mathrm{m}$ e um diâmetro médio de $18,25 \mu \mathrm{m}$.

\subsection{Caracterização da Escória de alto forno (GGBS)}

A escória de alto forno foi caracterizada através de ensaios de granulometria a laser e difração de raios-x.

\begin{tabular}{l|l}
\hline ANALYTO & RESULTADO \% \\
\hline $\mathrm{CaO}$ & 44,4959 \\
\hline $\mathrm{SiO}_{2}$ & 30,2153 \\
\hline $\mathrm{Al}_{2} \mathrm{O}_{3}$ & 7,9173 \\
\hline $\mathrm{Fe} 2 \mathrm{O} 3$ & 7,4460 \\
\hline $\mathrm{Cr} 2 \mathrm{O} 3$ & 3,7739 \\
\hline $\mathrm{SO}_{3}$ & 2,7058 \\
\hline $\mathrm{MnO}$ & 1,1034 \\
\hline $\mathrm{MgO}$ & 1,0802 \\
\hline $\mathrm{SrO}$ & 0,3687 \\
\hline $\mathrm{K} 2 \mathrm{O}$ & 0,3589 \\
\hline $\mathrm{NiO}$ & 0,2759 \\
\hline $\mathrm{Cl}$ & 0,2193 \\
\hline $\mathrm{Y} 2 \mathrm{O}_{3}$ & 0,0395 \\
\hline
\end{tabular}

Tabela 6: Composição química da escória de alto forno obtida por Difração de raios-x.

Observa-se que a escória de alto forno é composta principalmente de Cao (Óxido de cálcio) e $\mathrm{SiO}_{2}$ (Dióxido de silício).

A figura 8 mostra a distribuição granulométrica da escória de alto forno. 


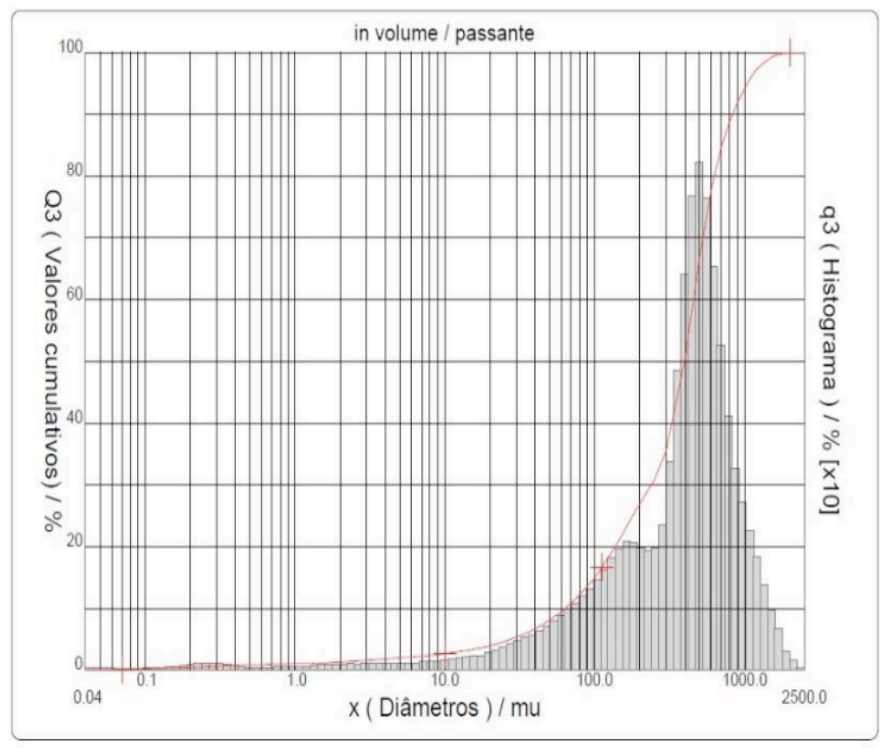

Figura 8: Distribuição granulométrica da escória de alto forno e curva cumulativa.

Observa-se pela curva de distribuição granulométrica que a matéria-prima da escória de alto forno apresenta uma faixa de distribuição granulométrica variando de 0,1 a $2500 \mu \mathrm{m}$, com $\mathrm{D}_{10}$ de $63,74 \mu \mathrm{m}, \mathrm{D}_{50}$ de $397,78 \mu \mathrm{m}, \mathrm{D}_{90}$ de $834,30 \mu \mathrm{m}$ e um diâmetro médio de $429,51 \mu \mathrm{m}$.

\subsection{Caracterização da Sílica Fume (SF)}

A sílica fume foi caracterizada através de distribuição granulométrica a laser, a qual está demonstrada na figura 9.

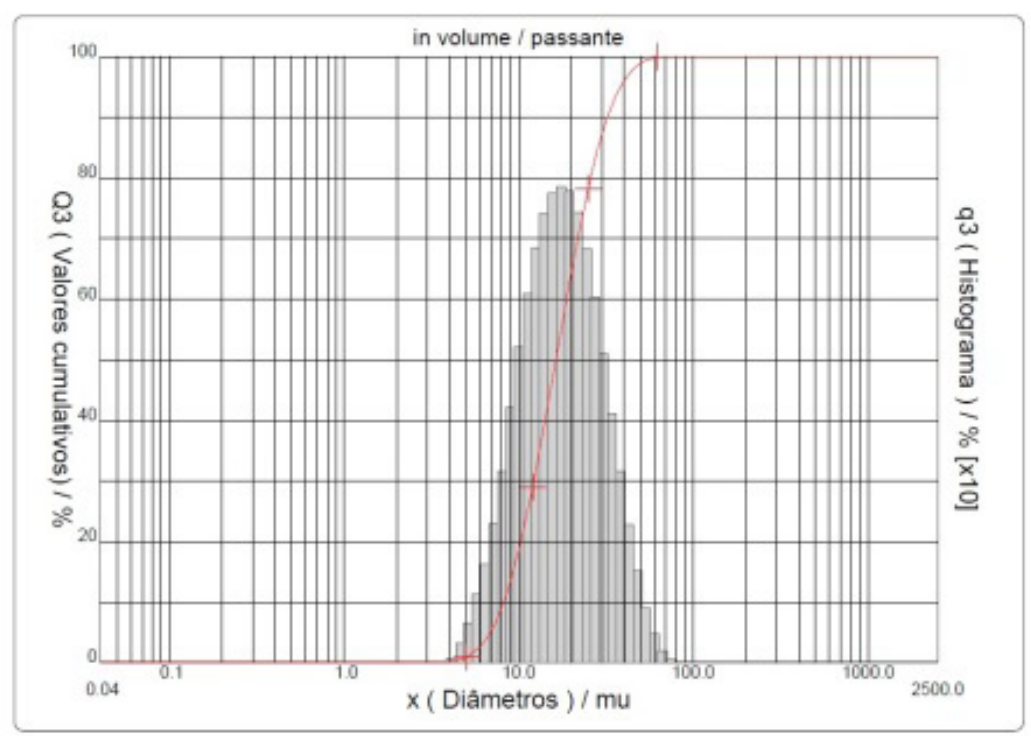

Figura 9: Distribuição granulométrica da sílica fume e curva cumulativa.

Observa-se pela curva de distribuição granulométrica que a matéria-prima da sílica fume apresenta uma faixa de distribuição granulométrica variando de 4 a $90 \mu \mathrm{m}$, com $\mathrm{D}_{10}$ de $8,22 \mu \mathrm{m}, \mathrm{D}_{50}$ de $16,33 \mu \mathrm{m}, \mathrm{D}_{90}$ de $32,33 \mu \mathrm{m}$ e um diâmetro médio 
de $18,62 \mu \mathrm{m}$.

\subsection{Caracterização da areia de sílica}

A areia de sílica foi caracterizada por granulometria a laser, a qual está mostrada na Figura 12.

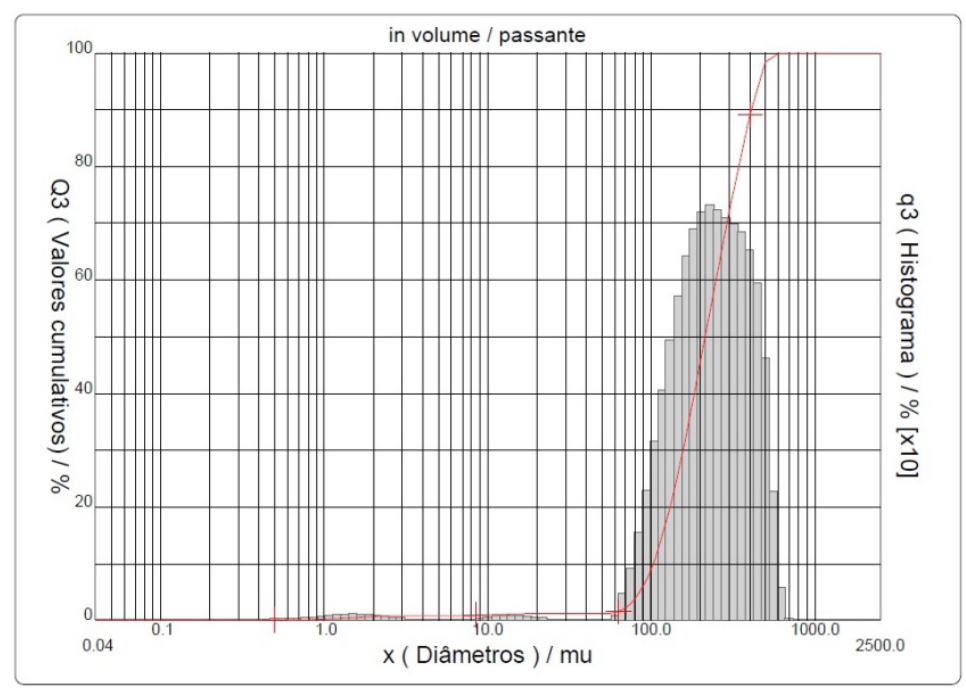

Figura 10: Distribuição granulométrica da areia de sílica e curva cumulativa.

Observa-se pela curva de distribuição granulométrica que a matéria-prima da areia apresenta uma faixa de distribuição granulométrica variando de 0,5 a 1000 $\mu \mathrm{m}$, com $\mathrm{D}_{10}$ de $102,79 \mu \mathrm{m}, \mathrm{D}_{50}$ de $213,59 \mu \mathrm{m}, \mathrm{D}_{90}$ de $408,40 \mu \mathrm{m}$ e um diâmetro médio de $236,93 \mu \mathrm{m}$.

\section{I RESULTADOS E DISCUSSÃO}

\subsection{Testes de resistência à compressão de CAR com Nanotubos de carbono.}

Ao se romper os primeiros corpos de prova aos 14 dias, observou-se que estes apresentavam consistência de um concreto com poucos dias de cura, mostrando assim um baixo resultado na compressão. Na Tabela 7 estão demostrados esses resultados. Em função disso, optou-se por rompê-los diretamente aos 28, 56 e 90 dias de cura. Os testes foram feitos de acordo com a NBR 5739 [17]

\begin{tabular}{l|l|l}
\hline MISTURA & fcm $(\mathrm{MPa})$ & DESVIO PADRÃO MÉDIO $(\sigma)$ \\
\hline CAR-1 & 19,93 & 0,02 \\
\cline { 2 - 3 } CAR-2 & 4,81 & 4,81 \\
\hline CAR-3 & 14,43 & 2,93 \\
\hline
\end{tabular}

Tabela 7: Resultados de resistência à compressão axial $(\mathrm{f} \mathrm{cm})$ das três primeiras misturas aos 14 dias de idade. 
Os resultados obtidos de resistência à compressão para as misturas nas idades de 28, 56 e 90 dias estão na Tabela 8.

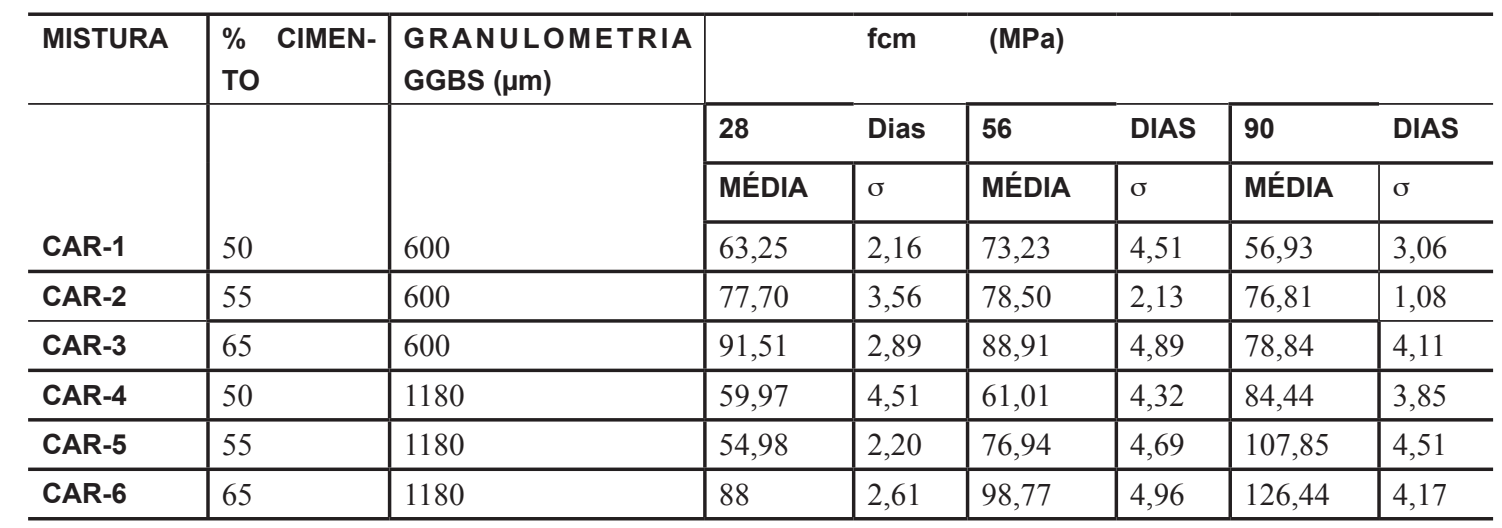

Tabela 8: Resistência à compressão axial (fcm) do concreto com adição de nanotubos de carbono.

Pode-se observar pelos resultados grandes diferenças de comportamento entre as misturas. A mistura 1 (CAR-1) mostrou um leve aumento na resistência aos 56 dias, reduzindo o valor novamente aos 90 dias. Acredita-se que houve pouca vibração dos corpos de prova e com isso aumento de poros internos que resultaram na diminuição da resistência à compressão. Como as misturas 1, 2 e 3 foram feitas com o mesmo tempo de vibração (30 segundos), acredita-se que o mesmo problema ocorreu. Após aumentou-se o tempo de vibração (de 30 segundos para 1 minuto) observou-se uma diminuição na quantidade de poros internos. Na mistura 4 (CAR4), que contém as mesmas quantidades de materiais, apenas a granulometria da escória de alto forno era menor, mostrou um resultado crescente de resistência ao longo dos 90 dias, comprovando que uma maior granulometria do GGBS é melhor para esse tipo de mistura, visto a quantidade de finos ser muito alta. Na mistura 2 (CAR-2), os resultados da compressão mostraram-se praticamente constantes, acredita-se que aos 28 dias todas as reações já estavam completas. Esses resultados estariam de acordo com Pelisser [20], em que cita que a hidratação do cimento se dá em três etapas e na terceira etapa é onde ocorre o aumento acentuado da resistência mecânica da mistura. Nesta etapa, ocorre a formação de silicato de cálcio hidratado a partir da reação entre a alita e belita presentes no clínquer com os produtos das etapas anteriores. Durante este processo, os grãos dos agregados ficam presos em meio à mistura, o que confere força e resistência ao concreto. Esta etapa da hidratação pode demorar meses para terminar, porém o maior ganho de resistência é atingido geralmente após um mês da aplicação do material. $\mathrm{Na}$ mistura 5 (CAR-5) que contém as mesmas quantidades de materiais, mudando apenas a granulometria da escória de alto forno (GGBS) mostrou um resultado de resistência mais baixo aos 28 dias, praticamente se igualando aos valores de 
resistência da mistura 2 aos 56 dias quando comparado à mistura 2, e alcançando resultados expressivamente melhores aos 90 dias. Novamente uma granulometria maior de GGBS influencia positivamente a resistência à compressão. Esperavase que a escória de alto forno (GGBS) com granulometria menor desse melhores resultados, uma vez que menor granulometria diminui a quantidade e o volume dos vazios presentes. A mistura 3 (CAR-3) apresentou melhores resultados aos 28 dias, mantendo praticamente constante aos 56 dias, com diminuição da resistência aos 90 dias. Essa diminuição da resistência pode ter sido por problemas de retração. De acordo com Aïtcin [21], nos concretos de alto desempenho uma relação água/ aglomerante bem pequena, em torno de 0,30 e uma pequena quantidade de cimento e água são utilizadas na mistura, de modo que a rede de poros é essencialmente composta de capilares finos. Quando a auto-dessecação começa a acontecer, com o início da hidratação, os meniscos rapidamente se desenvolvem em pequenos capilares se não for acrescentada água externa. Como muitos grãos de cimento começam a hidratar-se simultaneamente no concreto de alto desempenho, a secagem de capilares muito finos pode gerar tensões muito altas que encolhem a pasta de cimento hidratada.

A mistura 6 (CAR-6) que contém as mesmas quantidades de materiais, mudando apenas a granulometria da escória de alto forno (GGBS) mostrou um resultado completamente diferente, apresentando aumento da resistência em todas as idades, alcançando valores da ordem de 120MPa. Em função disso, o concreto com essa mistura pode ser considerado de ultra alta resistência. Novamente, uma granulometria maior de GGBS influencia positivamente na resistência à compressão.

Observando-se os resultados de resistência à compressão das misturas CAR4 e CAR-6 com a quantidade de cimento utilizada, nota-se que um incremento de $30 \%$ na quantidade de cimento fez com tivesse um ganho de quase $50 \%$ na resistência. As misturas CAR-3 e CAR-6 apresentam a mesma quantidade de cimento e demais materiais, diferenciando-se apenas a granulometria do GGBS, que na CAR-3 era de $850 \mu$ e na CAR- 6 era $1180 \mu$. A grande diferença nos resultados se deve a quantidade de finos na CAR-6 que é menor, fazendo com que os vazios sejam mais bem preenchidos.

Segundo Melo [23] o aumento obtido na resistência à compressão também está relacionado à dispersão dos nanotubos na matriz. Quando a dispersão é bem realizada, o nanotubo mistura-se à pasta de forma homogênea, fazendo interligações com o silicato de cálcio hidratado e com o próprio grão da mistura, sem ocorrer aglomerações pontuais. Isso leva a uma matriz mais densa, que contribui para a obtenção de um novo material mais resistente. Também os estudos de Musso et al [14] indicaram que as propriedades químicas e físicas dos NTC podem afetar o comportamento dos compósitos e que um teor de 0,5\% em massa de NTC aumentou 
a resistência à compressão de compósitos cimentícios em 20\%. Xu et al [22] em seus estudos verificaram que um teor de 0,2\% em massa de NTC aumentou a resistência à compressão em 14,5\%.

\subsection{Testes de compressão das misturas com cinza de casca de arroz}

A Tabela 9 apresenta os resultados dos testes de resistência à compressão de UHC com cinza de casca de arroz para cada traço moldado.. O valor demostrado é a média aritmética obtida de três resultados.

\begin{tabular}{|c|c|c|c|c|c|c|c|c|c|}
\hline MISTURA & \% CIMENTO & $\begin{array}{l}\% \\
\text { CCA }\end{array}$ & $\begin{array}{l}\text { GRANULOMETRIA } \\
\text { GGBS }(\mu \mathrm{m})\end{array}$ & & & $\mathrm{fcm}$ & (MPa) & & \\
\hline \multirow[b]{3}{*}{ CAR-7 } & \multirow[b]{3}{*}{50} & \multirow[b]{3}{*}{20} & \multirow[b]{3}{*}{600} & 7 & DIAS & 14 & DIAS & 28 & DIAS \\
\hline & & & & MÉDIA & $\sigma$ & MÉDIA & $\sigma$ & MÉDIA & $\sigma$ \\
\hline & & & & 77,1 & 4,91 & 77,1 & 1,89 & 78,50 & 2,22 \\
\hline CAR-8 & 55 & 20 & 600 & 81,6 & 5,49 & 84,1 & 4,00 & 113,8 & 7,20 \\
\hline CAR-9 & 65 & 10 & 600 & 88,9 & 6,61 & 90,2 & 4,44 & 93,55 & 1,15 \\
\hline CAR-10 & 50 & 15 & 1180 & 64,4 & 1,56 & 77,5 & 4,27 & 82,61 & 3,73 \\
\hline CAR-11 & 55 & 10 & 1180 & 54,7 & 1,81 & 85 & 2,87 & 92,68 & 2,48 \\
\hline CAR-12 & 75 & 10 & 1180 & 72,4 & 4,82 & 102,3 & 4,03 & 104,3 & 6,42 \\
\hline
\end{tabular}

Tabela 9: Resistência à compressão axial (fcm) das misturas contendo cinza de casca de arroz.

Observa-se que os melhores resultado aos 28 dias foram para as misturas 2 $(113,83 \mathrm{MPa})$ e 6 (104,32 MPa). As misturas 3 e 5 mostraram resultados semelhantes, em torno de $93 \mathrm{MPa}$. A mistura 1 foi a que apresentou resultado mais baixo, com $78,5 \mathrm{MPa}$ aos 28 dias.

A partir dessa tabela observa-se que os resultados obtidos que a melhor mistura foi a que continha 55\% de cimento e 20\% de CCA. Aumentando-se o teor de cimento e diminuindo o teor de CCA os resultados foram um pouco mais baixos.

Estes resultados estão de acordo com Kuntz [24] e Saraswathy [25] que afirmam que a adição de CCA aumenta a resistência à compressão, devido a densificação da matriz da pasta e da interface matriz-agregado, e, também, diminui a permeabilidade, devido ao fechamento de vazios do concreto e a um refinamento da estrutura dos poros. Também afirmam que teores muito elevados de CCA podem prejudicar o desempenho das misturas. Recomendam um teor de substituição abaixo de $30 \%$ em massa de cimento. Também para Biz [8], que realizou ensaios com teores de subsituição entre $10 \%$ e $30 \%$ de CCA em massa de cimento, $20 \%$ de CCA foi o teor que apresentou melhores resultados de resistência à compressão.

\section{I CONCLUSÕES}

No presente trabalho foi avaliado o desempenho de dois aglomerantes (NTC 
e CCA) inseridos em concretos de alta resistência. Foi avaliada a resistência à compressão axial com adição de $1 \%$ de NTC e de 10 a 20\% de CCA, assim como a influência da granulometria da escória de alto forno (GGBS).

Os resultados mostraram que ambos aglomerantes podem ser utilizados para obtenção de concretos de alta resistência com obtenção de valores de resistência à compressão de mais de 110MPa. Nos concretos com adição de NTC, tem de se ter um cuidado maior na primeira semana de cura, não se podendo fazer grandes esforços no concreto por apresentar baixa resistência inicial, mesmo se utilizando cimento Portland tipo CP-V de alta resistência inicial. Das misturas com NTC, a mistura contendo $10 \%$ de NTC, 55\% de cimento, 35\% GGBS $(1180 \mu \mathrm{m})$ e 10\% SF foi a que apresentou melhores resultados devido às propriedades físicas dos materias constituintes. Por tratar-se de pozolana altamente reativa, com alto teor de sílica amorfa e elevada finura, a sílica fume apresenta altíssima reatividade com os produtos decorrentes da hidratação do cimento, melhorando visivelmente seu desempenho. Também os NTC produzem na mistura uma pasta mais densa que leva a valores superiores de resistência. Para as misturas com CCA, a que continha $55 \%$ cimento, $15 \%$ GGBS $(600 \mu \mathrm{m}), 10 \%$ SF e $20 \%$ CCA foi a que apresentou melhores resultados. Da mesma forma que a sílica fume, a CCA é uma pozolana altamente reativa, que apresenta reatividade com os produtos decorrentes da hidratação do cimento, melhorando seu desempenho. Assim, o uso de sílica fume e CCA melhoram o desempenho de concretos em determinadas faixas de uso. Observa-se que tanto para a mistura com NTC quanto para a mistura contendo CCA os resultados foram melhores quando se utilizou as proporções de $55 \%$ cimento e 10\% SF. Para a mistura com NTC foi necessário uma quantia maior de GGBS e com maior granulometria. Destre as proporções de CCA utilizadas, os melhores resultados foram obtidos com a utilização de $20 \%$.

Pelo lado econômico, mesmo os NTC sendo fabricando no LEME, os custos com esse concreto são muito maiores que com a utilização de CCA.

Portanto, cabe salientar que a adição de CCA é benéfica para a produção de concreto, aumentando sua resistência. Com a redução da quantidade de cimento, o qual é produzido através da extração de recursos minerais, e aplicação de CCA e GGBS em concretos, introduz-se no processo materiais sustentáveis.

\section{AGRADECIMENTOS}

Os autores agradecem ao apoio da Universidade Federal do Rio Grande do Sul (UFRGS) por possibilitar o empenho de seus professores/pesquisadores e colocar sua infraestrutura à disposição deste trabalho de pesquisa, à empresa CAMARGO QUÍMICA LTDA pela doação do superplastificante, e à empresa SVA SILICA VERDE DO ARROZ LTDA pela doação da cinza de casca de arroz. Além disso, deve-se 
registrar o agradecimento pela concessão de bolsas de estudo promovidas pela Coordenação de Aperfeiçoamento de Pessoal de Nível Superior (CAPES).

\section{REFERÊNCIAS}

[1 ] AMORIM, A.A., Durabilidade das estruturas de concreto armado aparentes. Monografia. UFMG, Belo Horizonte, 2010.

[2] KUMAR, S., GUPTA, R.C., SHRIVASTAVA, S., CSETENYI, L., THOMAS, B.S., " Preliminary study on the use of quartz sandstone as a partial replacement of coarse aggregate in concrete based on clay content, morphology and compressive strength of combined gradation". Construction and Building Materials, v. 107, pp.103-108, 2016.

[3] SIEG, A.P.A, Concretos de Pós Reativos- Estudo das adições minerais: cinza de casca de arroz, metacailim e sílica ativa. Dissertação M.SC. UNIPAMPA, Alegrete, Brasil, 2012.

[4] THOMAS, B.S, "Green concrete partially comprised of rice husk ash as a supplementary cementitious material - A comprehensive review", Renewable and Sustainable Energy Reviews, v.82, pp. 3913-3923, 2018

[5] NETTO, R.M., Materiais pozolânicos. Monografia. UFMG. Belho Horizonte, Brasil, 2006.

[6] RODRIGUES, M.S., Caracterização de cinza residual da queima de casca de arroz para a produção de argamassa. Dissertação M.SC. UNICAMP, Campinas, 2008.

[7] AMERICAN CONCRETE INSTITUTE. Committee 363R-92 (Reapproved 1997). State of the art reporte on high strength concrete. ACI Manual of Concrete Practice, part 1. Farmington Hills: ACl, 1998.

[8] BIZ, C.E., Concreto de Pós Reativos. Dissertação M.Sc. Unicamp. São Paulo, Brasil, 2001.

[9] FEHLING, E., SCHMIDT, M., WALRAVEN, T., LEUTBECHER, T., FROHLICH, S, “Ultra High Performance Concrete UHPC Fundamentals, Design, Examples". First Edition, 2014, 188p.

[10] ISAIA, G.C., Concreto: Ciência e Tecnologia, v.1 e 2. Ibracon, 2010.

[11] REGÔ, J.H.S., As cinzas de casca de arroz (CCAS) amorfa e cristalina como adição mineral ao concreto - Aspectos da microsestrutura das pastas. Tese de D.Sc, UNB, Brasília, Brasil, 2004.

[12] LI, G.Y., WANG, P.M., ZHAO, X. "Mechanical behavior and microestruture of cement composites incorporating surfasse-treated multi-walled carbono nanotubes" Carbon, v. 43, pp. 1239-1245, 2005.

[13] SOBOLKINA, A., MECHTCHERINE, V., KHAVRUS, V., LEONHARD, A., "Dispersion of carbon nanotubes and its influence on the mechanical properties of cement matrix", Cement $\varepsilon$ Concrete Composites, v. 34, pp.1104-1113, 2012.

[14] MUSSO, S., TULLIANI, J.M., FERRO, G., TAGLIAFERRO, A., "Influence of carbon nanotubes structure on the mechanical behavior of cement composites", Composites Science and Technology, v. 69, pp.1985-1990, 2009.

[15] PACHECO-TORGAL, F., JALALI, S., "Nanotechnology: Advantages and drawbacks in the field of construction and building materials", Construction and Building Materials, v.25, pp.582-590, 2011.

[16] SIDDIQUE, R., MEHTA, A., "Effect of carbon nanotubes on properties of cement mortars", Construction and Building Materials, v. 50, pp. 116-129, 2014. 
[17] ASSOCIAÇÃO BRASILEIRA DE NORMAS TÉCNICAS . NBR 5739: Concreto: ensaio de compressão de corpos-de-prova cilíndricos. Rio de Janeiro, 1994.

[18] CIMENTOS ITAMBÉ. Referência obtida na Internet. < http://www.cimentoitambe.com.br/cimentos/ cp-v-ari-cimento-portland-alta-resistencia/> Acesso em nov/2017.

[19] ASSOCIAÇÃO BRASILEIRA DE NORMAS TÉCNICAS. NBR 5738: Concreto: procedimento para moldagem e cura de corpos-de-prova. Rio de Janeiro, 2003.

[20] PELISSER, P., STANER, L.R., BERNARDIN, A.M, "Recycling of porcelain tile polishing residue in Portland cemen: hydration efficiency", Environmental Science \& Technology, v. 46, pp. 2368-2374, 2012.

[21] AÏTCIN, P.C., A arte e a ciência do concreto de alto desempenho. Roma, 1997.

[22] XU, S., LIU, J., LI,Q., "Mechanical properties and microstructure of multi-walled carbon nanotubereinforced cement paste", Construction and Building Materials, v. 76, pp.14-23, 2015.

[23] MELO, V.S., Efeito da mistura física de nanotubos de carbon em matrizes de cimento Portland. Dissertação M.SC., UFMG, Belo Horizonte, 2009.

[24] KUNTZ, L.M., The Greening of the Concrete Industry: Factors contributing to Sustainable Concrete. Thesis M.Sc. Massachusetts Technology Institute. Cambridge, 2006.

[25]SARASWATHY,V.\& SONG, H-W., "Corrosion performance of rice husk ash blended concrete." Construction and Building Materials", v.21, p. 1779-1784, 2007 
HENRIQUE AJUZ HOLZMANN - Professor da Universidade Tecnológica Federal do Paraná (UTFPR). Graduação em Tecnologia em Fabricação Mecânica e Engenharia Mecânica pela Universidade Tecnológica Federal do Paraná. Mestre em Engenharia de Produção pela Universidade Tecnológica Federal do Paraná Doutorando em Engenharia e Ciência do Materiais pela Universidade Estadual de Ponta Grossa. Trabalha com os temas: Revestimentos resistentes a corrosão, Soldagem e Caracterização de revestimentos soldados.

JOÃO DALLAMUTA - Professor da Universidade Tecnológica Federal do Paraná (UTFPR). Graduação em Engenharia de Telecomunicações pela UFPR. MBA em Gestão pela FAE Business School, Mestre em engenharia elétrica pela UEL. Doutorando em Engenharia Espacial pelo INPE.

RICARDO VINICIUS BUBNA BISCAIA - Professor da Universidade Tecnológica Federal do Paraná (UTFPR). Graduado em Engenharia Mecânica pela Universidade Tecnológica Federal do Paraná. Mestre em Engenharia Mecânica pela Universidade Tecnológica Federal do Paraná Doutorando em Engenharia de Produção pela UTFPR. Trabalha com os temas: análise microestrutural e de microdureza de ferramentas de usinagem, modelo de referência e processo de desenvolvimento de produto e gestão da manutenção. 
ÍNDICE REMISSIVO

A

Aço $3,8,9,10,11,13,15,17,19,20,22,23,24,25,27,28,29,31,37,93$

Aerogeradores 1, 3, 4, 6

Amazônia 8, 80

B

Baja 8, 21, 22, 23, 24, 25, 31, 32

Bauxita 8, 80, 81, 82, 83, 85

C

Chapas $8,9,10,15,17,18,19$

Coco babaçu 9, 87, 89, 92, 93

Compósitos 8, 33, 34, 35, 38, 40, 42, 45, 48, 49, 50, 54, 55, 56, 57, 58, 59, 60, 71, 87, 88, $89,92,108,109$

Compósitos Poliméricos Híbridos 33

Concreto 9, 3, 87, 90, 91, 92, 93, 94, 95, 96, 99, 106, 107, 108, 109, 110, 111, 112

Critérios de falha 33,35

E

energia $7,1,2,3,4,5,6,7,29,67,69,88,91$

Energia 6, 7, 20, 71

ENERGIA 8, 1

Ensaios 8, 9, 11, 15, 19, 20, 21, 23, 24, 26, 27, 30, 31, 33, 35, 37, 42, 45, 72, 73, 74, 75, 77, 94, 96, 97, 98, 99, 102, 104, 109

Ensaios Mecânicos 19, 21, 24

Eólica 8, 1, 2, 3, 4, 5, 7

$\mathbf{F}$

Ferroelétricos 48, 49, 55, 59

Fibras 8, 9, 33, 34, 36, 37, 42, 43, 44, 45, 87, 88, 89, 90, 91, 92, 93

Fratura $33,35,38,40,41,42,43,45$

Furo Central 33, 36, 39, 40, 42, 45

G

Gaiola 21, 22, 23 
katoita $8,80,81,82,83,84,85$

$\mathbf{P}$

Parques 8, 1, 2, 3, 4, 5, 6, 7

Propriedades $8,9,8,9,15,19,20,21,24,25,30,31,34,35,36,37,38,39,41,44,46,48$, $49,51,54,56,59,87,88,89,90,92,93,95,96,99,102,108,110$

PVDF $8,48,49,50,51,52,53,54,55,56,57,58,59,60,61$

$\mathbf{R}$

Rejeitos 8, 80, 81, 82

Resistência 9, 6, 19, 24, 28, 33, 35, 37, 38, 39, 40, 41, 42, 44, 45, 48, 68, 72, 87, 88, 90, $91,92,94,95,96,97,98,99,106,107,108,109,110$

Resistência Residual 33, 35, 38, 39, 44, 45

S

SAE $8,9,20,21,22,23,24,25,27,28,29,31,32$

Soldagem 21, 23, 26, 28, 29, 31, 32, 113

V

Ventos $1,2,3,4,5,6,7$

$\mathbf{Z}$

ZTA 21, 24, 28, 29, 30 


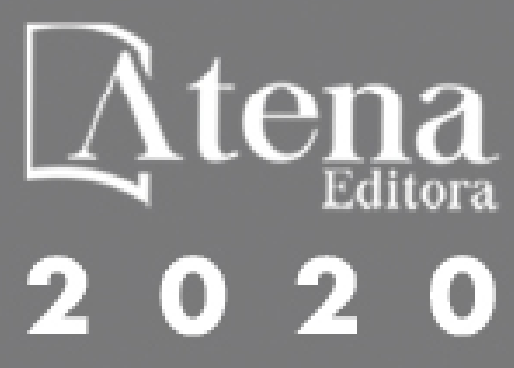

